\title{
Land Use Baseline Report Savannah River Site (U)
}

by

J. C. Noah

Westinghouse Savannah River Company

Savannah River Site

Aiken, South Carolina 29808

\section{DISCLAIMER}

\begin{abstract}
This report was prepared as an account of work sponsored by an agency of the United States Government. Neither the United States Government nor any agency thereof, nor any of their employees, makes any warranty, express or implied, or assumes any legal liability or responsibility for the accuracy, completeness, or usefulness of any information, apparatus, product, or process disclosed, or represents that its use would not infringe privately owned rights. Reference herein to any specific commercial product, process, or service by trade name, trademark, manufacturer, or otherwise does not necessarily constitute or imply its endorsement, recommendation, or favoring by the United States Government or any agency thereof. The views and opinions of authors expressed herein do not necessarily state or reflect those of the United States Government or any agency thereof.
\end{abstract}

\section{MASTER}

DOE Contract No. DE-AC09-89SR18035

This paper was prepared in connection with work done under the above contract number with the U.S.

Department of Energy. By acceptance of this paper, the publisher and/or recipient acknowledges the U.S. Government's right to retain a nonexclusive, royalty-free license in and to any copyright covering this paper, along with the right to reproduce and to authorize others to reproduce all or part of the copyrighted paper. 


\section{DISCLAIMER}

Portions of this document may be illegible in electronic image products. Images are produced from the best available original document. 
This document was prepared by the Savannah River Site Land-Use Technical Committee under the direction of the Westinghouse Land-Use Steering Committee.

\title{
SAVANNAH RIVER SITE LAND-USE TECHNICAL COMMITTEE
}

\author{
J. Christopher Noah, Chair
}

\author{
WESTINGHOUSE SAVANNAH RIVER COMPANY \\ John W. Cook \\ R. Michael Cutshall \\ John N. Dewes \\ Ronald Y. Garrison \\ John B. Gladden \\ Donald E. Gordon \\ W. Dean Hoffman \\ David M. Isiminger, Jr. \\ James D. Lengle \\ Willie L. Leslie, Jr. \\ William M. Rajczak \\ James R. Schornhorst \\ Dale E. Stephenson \\ Gary H. Street \\ Richard W. Swygert \\ U.S. FOREST SERVICE \\ John G. Irwin \\ Thomas O. Smith \\ Stephen E. Stine \\ U.S. NATURAL RESOURCES CONSERVATION SERVICE \\ Bobby D. McGee \\ UNIVERSITY OF GEORGIA \\ (SAVANNAH RIVER ECOLOGY LABORATORY) \\ Laura L. Janecek \\ UNIVERSITY OF SOUTH CAROLINA \\ (SAVANNAH RIVER ARCHAEOLOGICAL RESEARCH PROGRAM) \\ Mark J. Brooks \\ Richard D. Brooks \\ HALLIBURTON/NUS \\ Daniel Evans
}

This document was prepared by the Westinghouse Savannah River Company under contract No. DE-ACO9-89SR18035 with the United States of America, represented by the Department of Energy. Neither the U.S. Government nor Westinghouse Savannah River Company nor any of their employees makes any warranty, expressed or implied, or assumes any legal liability or responsibility for any apparatus, product, or process disclosed, or represents that its use would not infringe on privately owned rights. References herein to any specific commercial products, process, or service by trade name, trademark, manufacturer, or otherwise does not necessarily constitute or imply its endorsement, recommendation, or favoring by the U.S. Government or Westinghouse Savannah River Company. 


\section{Land-Use Baseline Report}

\section{Savannah River Site}

Compiled By
J. Christopher Noah, Land-Use Coordinator
Strategic Programs and Planning
Westinghouse Savannah River Company
Edited By
Albert R. Mamatey, Technical Editor
Environmental Protection Department/Environmental Monitoring Section
Westinghouse Savannah River Company

\section{June 1995}




\section{Acknowledgments}

Gratitude is expressed to the following individuals-in addition to the public reviewers, the U.S. Department of Energy, the Westinghouse Land-Use Steering Committee, and the Savannah River Site Land-Use Technical Committee-for their expert assistance in the production of this document:

- WESTINGHOUSE SAVANNAH RIVER COMPANY

Donnie J. Green, Senior Draftsman, Site Development, Control, and Mapping

David M. Isiminger, Jr., Site Mapping Coordinator, Facilities and Services

Gail F. Jernigan, Environmental Scientist, Integrated Site and Systems Planning

Robert E. Meadors, Manager, Integrated Site and Systems Planning

Joan K. Toole, Customer Service Representative, Printing Services

- U.S. DEPARTMENT OF ENERGY-SAVANNAH RIVER OPERATIONS OFFICE

Donald O. Druelle, Deputy Director, Site Services Division 


\section{Table of Contents}

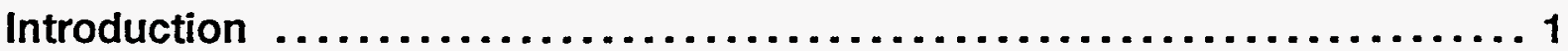

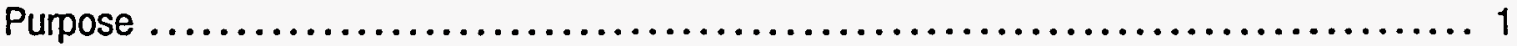

Related Studies/Plans $\ldots \ldots \ldots \ldots \ldots \ldots \ldots \ldots \ldots \ldots \ldots \ldots \ldots \ldots \ldots \ldots \ldots \ldots \ldots \ldots, 1$

Regional Profile .............................................. 3

Physical Description/Environmental Resources $\ldots \ldots \ldots \ldots \ldots \ldots \ldots \ldots \ldots \ldots \ldots \ldots, \ldots \ldots \ldots$

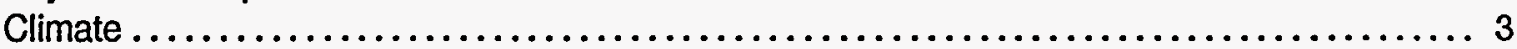

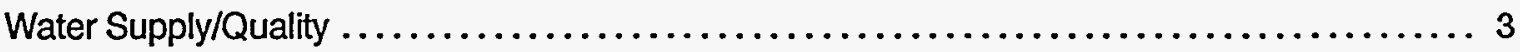

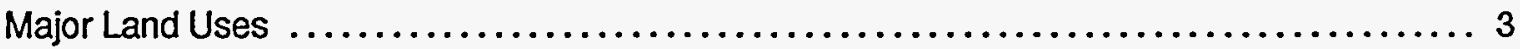

Land-Use Regulation .................................................... 4

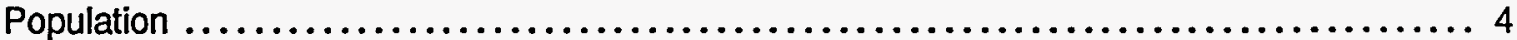

50-Mile Radius of Concern .................................................. 4

Economic Activity $\ldots \ldots \ldots \ldots \ldots \ldots \ldots \ldots \ldots \ldots \ldots \ldots \ldots \ldots \ldots \ldots \ldots \ldots \ldots, 4$

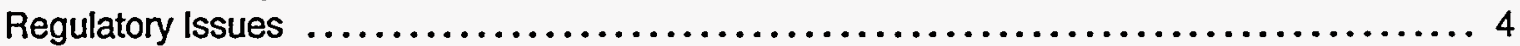

Federal, State, and Local Governing Organizations $\ldots \ldots \ldots \ldots \ldots \ldots \ldots \ldots \ldots \ldots \ldots \ldots, 4$

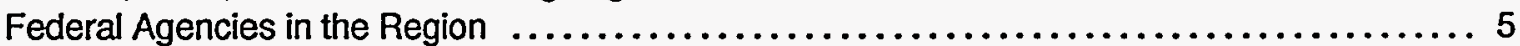

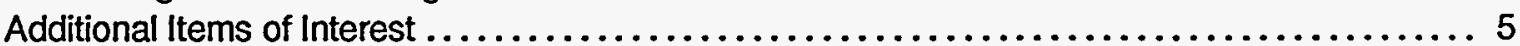

History of the CSRA $\ldots \ldots \ldots, \ldots, \ldots, \ldots, \ldots, \ldots, \ldots, \ldots, \ldots, \ldots, \ldots, \ldots, 5$

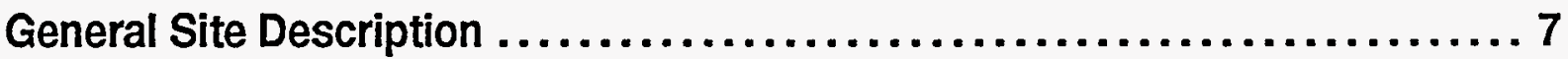

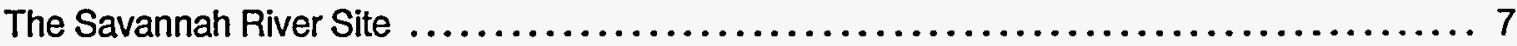

Land-Use Planning at the Savannah River Site $\ldots \ldots \ldots \ldots \ldots \ldots \ldots \ldots \ldots . . . . . . .6$

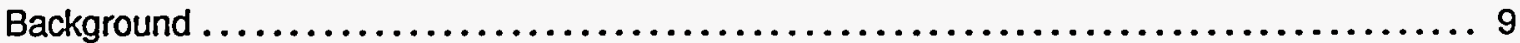

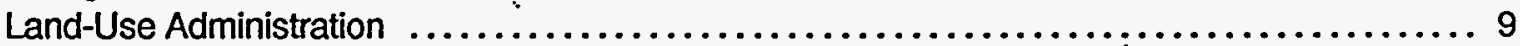

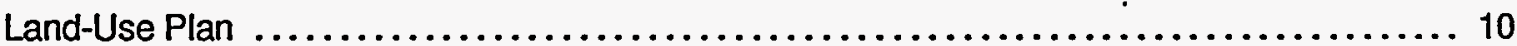

Policy Guidelines for Land Use $\ldots \ldots \ldots \ldots \ldots \ldots \ldots \ldots \ldots \ldots \ldots \ldots \ldots \ldots \ldots \ldots, 10$

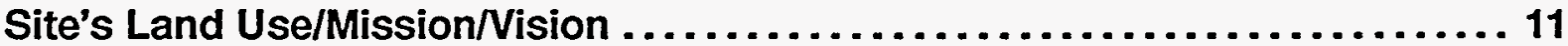

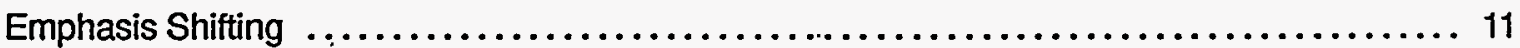

Site Mission/Vision $\ldots \ldots \ldots \ldots \ldots \ldots \ldots \ldots \ldots \ldots \ldots \ldots \ldots \ldots \ldots \ldots \ldots \ldots \ldots \ldots, 11$

Current Use $. . . \ldots \ldots \ldots \ldots \ldots \ldots \ldots \ldots \ldots \ldots \ldots \ldots \ldots \ldots \ldots \ldots \ldots \ldots, 12$

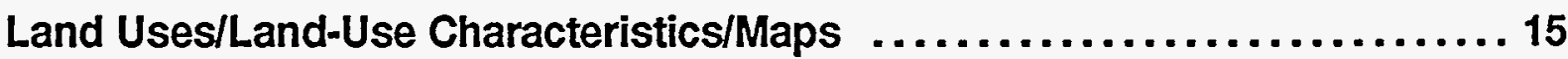

Administrative/Nonnuclear Facilities $\ldots \ldots \ldots \ldots \ldots \ldots \ldots \ldots \ldots \ldots \ldots \ldots \ldots \ldots, 16$

Nuclear Industrial Facilities $\ldots \ldots \ldots \ldots \ldots \ldots \ldots \ldots \ldots \ldots \ldots \ldots \ldots \ldots \ldots \ldots \ldots \ldots, 18$

Land Use and Radiological Risk $\ldots \ldots \ldots, \ldots \ldots \ldots, \ldots \ldots \ldots, \ldots, \ldots, \ldots, \ldots, 20$

Technology Demonstrations $\ldots \ldots \ldots \ldots \ldots \ldots \ldots \ldots \ldots \ldots \ldots \ldots \ldots \ldots \ldots \ldots \ldots, \ldots \ldots \ldots, 22$

Utilities .............................................................. 24

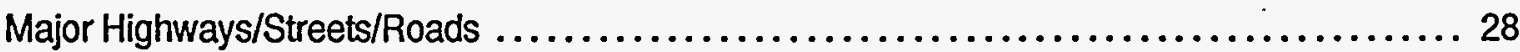

Railroads/Waterborne Transport ......................................... 30

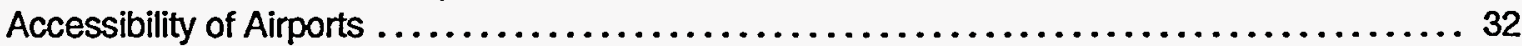

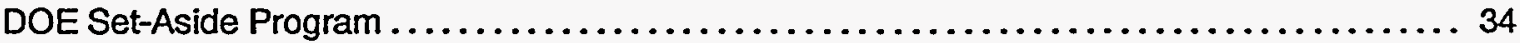

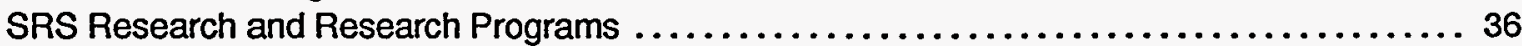

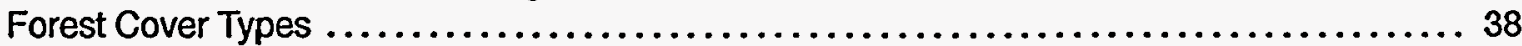

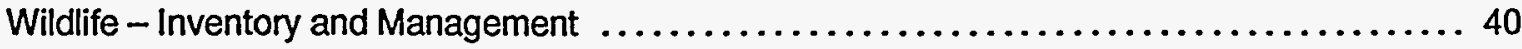


Threatened/Endangered/Sensitive-Species Management . ...................... 42

Fire Management .................................................. 44

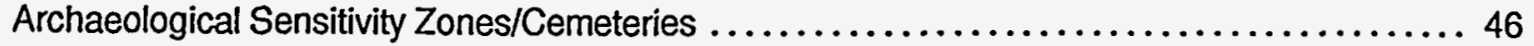

Recreation ..................................................... 48

Topography/Cadastral ............................................ 50

Surface Water ................................................. 54

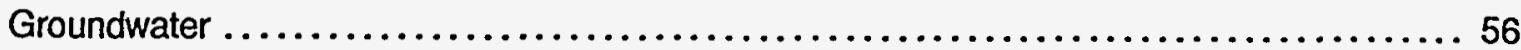

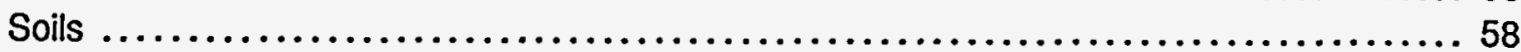

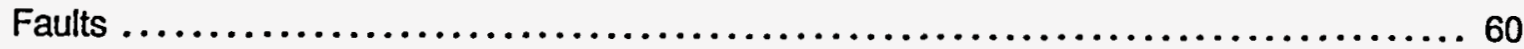

Geology ......................................................... 62

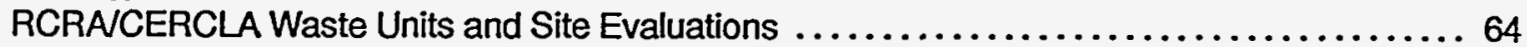

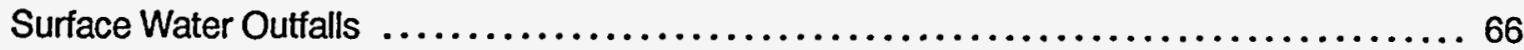

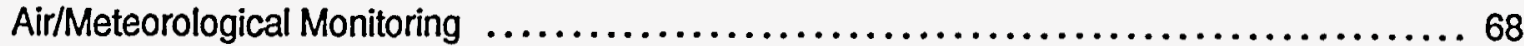

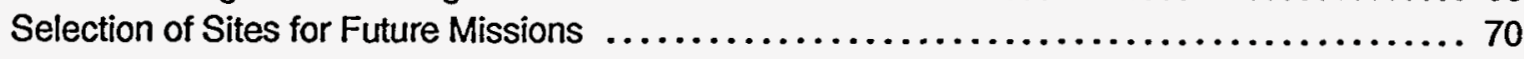

Laws/Regulations/DOE Orders/Policies Affecting

SRS Land Use/Transfer . . . . . . . . . . . . . . . . . . . . . . . . . . . . . . . . . 73

Laws/Regulations ............................................... 73

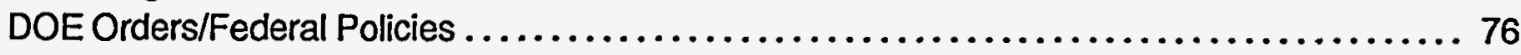

Land Use-Related Environmental

Acts/Regulations/Executive Orders $\ldots \ldots \ldots \ldots \ldots \ldots \ldots \ldots \ldots \ldots \ldots \ldots . \ldots 1$ 


\section{Chapter 1}

\section{Introduction}

\section{Purpose}

This document is to serve as a resource for Savannah River Site (SRS) managers, planners, and SRS stakeholders by providing a general description of the site and land-use factors important to future use decisions and plans. U.S. Department of Energy (DOE) sites are to respond to the direction of DOE Headquarters (DOE-HQ) in land-use planning, as stated in the DOE-HQ document, "Forging the Missing Link: Resource Document for Identifying Future-Use Options," regarding future-use planning:

"A comprehensive baseline of data and information must be identified and compiled in order to make an informed identification of preferred future-use options."

This document is an effort to describe SRS and the surrounding area in terms of its physical and natural features (e.g., climate, topography, geology, hydrology, soils, and surface waters) and its environmental conditions.

In identifying and compiling a comprehensive baseline of data and information for the evaluation of future-use options against a range of planning horizons, three main categories of data and information are essential. They are

- an overview of DOE missions and site requirements

- a description of the site and of the characteristics of the land (natural and manmade)

- a definition of applicable laws, regulations, and other requirements

Many decisions on possible future missions are pending and are discussed in planning documents such as the Site Development Plan. A number of these decisions will be impacted by land-use issues, including current uses, characteristics (e.g., environmental contamination, manmade and natural features, etc.), and resource management programs.

The effective evaluation of future-use options requires the understanding of the unique identity, characteristics, and relationships of the site, its geographic surroundings, and the dynamic linkages and interrelationships that must be considered in the selection of preferred future-use options. For example, the future use could affect or be affected by the surrounding area's land-use patterns or economic trends. To this end, the following data and information are presented:

- a description of the sitephysical characteristics and contamination profiles

- a demographic, cultural, economic, political, and regional land-use profile

- a description of regional physical and natural features and environmental conditions

Baseline information also is provided regarding waste management and remediation technologies. These activities are described with emphasis on emerging technologies that address particular problem waste streams and/or contamination concerns.

The intent of this document is to be comprehensive in its review of SRS and the surrounding area. Some of its data may not appear to contribute directly to future-use planning. However, once the baseline information on inherent site and regional demographic and economic characteristics, political and institutional relationships, cultural and historical resources, and land-use history is better understood, future-use-option scenarios will be easier to formulate. Also, this report should be viewed as part of a dynamic process. Data essential to the land-use process are continuously being developed and revised; consequently, future updates of this report may reflect changing land uses.

\section{Related Studies/Plans}

In 1993, the director of the Environmental and Laboratory Programs Division of DOE's Savannah River Operations Office (DOE-SR) sponsored a review of planning activities related to environmental issues at SRS. The purpose of the review was to:

- identify SRS.environmental plans and the organizations that prepare those plans

- facilitate communication between organizations that prepare environmental plans and those that actually or potentially are affected by the plans

This activity identified 20 organizations and 13 committees involved in SRS environmental planning. Seventy environmental and 64 nonenvironmental plans were identified. Of the 70 environmental plans, the 
following 21 (listed alphabetically) were identified as major planning documents that have broad application across the site:

- Capital Assets Management Plan

- Environmental Compliance Division Environmental Management Plan

- Environmental Implementation Plan

- Environmental Implementation Plan Action Plan

- Natural Resources Management Operations Plan of the SRS

- Natural Resources Management Plan; Strategic Guidance for the SRSNatural Resources Programs

- Pollution Abatement Plan

- Savannah River Ecology Laboratory (SREL) Annual Operating Plan

- SREL Strategic Plan

- SRS Decontamination and Decommissioning (D\&D) Program Management Plan
- SRS Five-Year Plan

- SRS Fiscal Year Operational Plan

- SRS Planning Manual

- SRS Site Development Plan

- SRS Site-Specific Plan

- SRS Strategic Plan

- SRS Facilities Transition Plan

- Savannah River Technology Center(SRTC) Quality Improvement Plan

- Strategic Plan for Environmental Compliance

- Thirty-Year Plan

- Transition Plan

The other 49 environmental plans had a narrower environmental focus. Examples of these plans include the SRS Best Management Practices Plan, the Air Quality Program Activities Plan, and the Timber Management Operations Plan. 


\section{Chapter 2}

\section{Regional Profile}

\section{Physical Description/ Environmental Resources}

SRS is located in the Central Savannah River Area (CSRA), which consists of nine counties in South Carolina (Aiken, Allendale, Bamberg, Bamwell, and Edgefield) and Georgia (Burke, Columbia, McDuffie, and Richmond) ${ }^{1}$. The site's southwestem boundary is formed by the Savannah River, a historical transportation corridor and the recipient of most of the area's tributaries. The river is used primarily to support industry, recreation, and natural-habitat development. SRS is situated in three major land resource areas: the Southern Piedmont, the Carolina and Georgia Sand Hills, and the Atlantic Coastal Plain. This is typical of land forms that came about as a result of marine sediment deposited in central and eastern Georgia 20 to 40 million years ago.

\section{Climate}

The area around SRS has short, mild winters, moderate autumns, warm springs, and warmer summers with an annual average temperature of 64 degrees Fahrenheit. The climate stays within the U.S. average range of annual precipitation (44 inches), and snowfall is rare.

\section{Water Supply/Quality}

Because of the land's characteristics and the site's proximity to the Savannah River, soil conservation, flood plain management, and-more recently-wetland issues play a large part in local planning. Area residents have long recognized the value of the river and its environs, and much of their recreational life centers around water activities. Thurmond Lake $(1,200$ miles of shoreline), other lakes, and the Savannah River offer swimming, fishing, camping, water skiing, boating, and hiking.

To maintain water quality for industrial, recreational, and residential use, development plans and a monitoring program are essential for both the functional integrity of the area and the safety, health, and property of the area's citizens.

Both the Savannah River and aquifers in the area provide an abundant supply of water. Groundwater is used throughout the CSRA as a domestic, municipal, industrial, and agricultural water supply. Most of the domestic supply of groundwater within the CSRA is produced from the Floridan aquifer system, while the remaining supplies are produced primarily from the Cretaceous age Dublin/Midville aquifer system. The groundwater production from the prolific Dublin/Midville aquifer system is about 50 million gallons per day within the CSRA. At SRS, the Dublin/Midville aquifer system provides about 9-12 million gallons per day for industrial uses and for drinking water for the site work force.

To a very limited extent, such as at remote guard houses, water is removed from the more shallow Tertiary aquifer. In rural areas, private wells typically withdraw water from the Tertiary aquifer as well.

There are approximately 120 public water systems in the region. All but four of the county and municipal water supply systems obtain their water from the Dublin/Midville aquifer system. The region has 14 major public sewage treatment facilities.

\section{Major Land Uses}

Land use in the area centers around residential, industrial, commercial, transportation, recreation, and agricultural categories. Upland pine and wetland forests comprise a large percentage of the area. Nonforested wetlands occur primarily along Thurmond Lake and the Savannah River.

The topography and other existing physical features and conditions of the area greatly influence land development decisions and policies. Because of the soil types and lack of steep slopes, the area is well-suited for both agriculture and urban development. The areas surrounding Augusta, Georgia, and Aiken, South Carolina, are used primarily for agriculture, with growing areas of residential, commercial, and

\footnotetext{
1 Planners in the area have no precise definition of the boundaries of the CSRA. Disarssions with the planners indicate that the boundaries change definition depending on the geographic perspective of the planner. Consequently, for this report, "CSRA" refers to those counties in which activities, commerce, and population would be seriously affected should a facility the magnitude of SRS not exist.
} 
industrial activity becoming more prevalent. Augusta, the Fort Gordon Military Reservation, and SRS comprise a significant amount of the total developed area.

Forest lands, which dominate land cover in the CSRA, are divided between bottomland hardwood/deciduous, cypress/tupelo, and pine-the most dominant. Although forest lands occur throughout the area, the greatest concentrations of pine are in the northwest portion, with bottomland hardwood/deciduous and cypress/tupelo forests primarily in stream valleys.

Major governmental jurisdictions in the area include Aiken, Allendale, Bamberg, Barnwell, Bath, Belvedere, Blackville, Denmark, Fairfax, New Ellenton, North Augusta, and Williston in South Carolina and Appling, Augusta, Evans, Grovetown, Martinez, Thomson, and Waynesboro in Georgia.

\section{Land-Use Regulation}

The land-use controls or planning tools most commonly used by local and county governments in Aiken, Allendale, Barnwell, Burke, Columbia, and Richmond counties are zoning ordinances, subdivision regulations, building codes and permits, and the regulation of mobile homes and trailer park development. Planning tools that are not widely used-or that are totally absent-are development standards, utility extensions or moratoriums, floodplain regulations, environmental regulations, and tax incentives.

\section{Population}

In 1990, the population of the CSRA was 492,062 . Most of this population lived in Aiken, Columbia, and Richmond counties. Augusta was the largest city, with a population of 44,639 . In 1990, 73.3 percent of the population lived in areas classified as urban. The urban-rural mix of the region is the same as that of the United States in general. The mix in the region, however, is more urban than other areas in South Carolina and Georgia.

The population density of the region was almost twice that of the nation in 1990, with approximately the same percentage of female and male inhabitants. Thirtyseven percent of the CSRA population is classified as minority. This compares to the national average of 12 percent black and 8 percent of other ethnicity.

The region as a whole experienced steady population growth between 1970 and 1990. The total estimated resident population in 1990 for the area within 10 to 50 miles of SRS was 590,000 . The total estimated population in 1990 for the area within 5 miles of the site was 37,000 .

\section{0-Mile Radius of Concern}

The 50-mile radius of safety concern is the geographical area required by Nuclear Regulatory Commission (NRC) regulatory guides and for which a Safety Analysis Report must include population information. The only people on the "limited-access" SRS are members of the work force required to accomplish DOE's mission.

\section{Economic Activity}

The major economic sectors in the region are agriculture, forestry, fishing, mining, construction, manufacturing, transportation, wholesale trade, retail trade, finance, insurance, real estate, services, and government. Manufacturing and government account for the largest portion of employment in the region (44.8 percent of all jobs).

\section{Regulatory Issues}

SRS is governed by several tiers of laws. Environmental laws and rules of implementation are administered and enforced by the federal government through the State of South Carolina. The state has federal authority from the U.S. Environmental Protection Agency (EPA) to enforce state environmental laws at SRS, in lieu of federal enforcement of air, water, and solid and hazardous waste laws. The site and its subcontractors also are governed by DOE orders.

The Savannah River watershed is controlled largely by the U.S. Army Corps of Engineers. Because water plays such a large part in both aesthetics and development within the region, area planners encourage continuous monitoring to protect groundwater recharge areas, aesthetics, and other water uses, even beyond statutory requirements.

\section{Federal, State, and Local Governing Organizations}

The region has federal, state, regional, and local governments and special-purpose districts that administer and fund programs and services, enact laws and regulations, and formulate policy. Local governments are organized in a variety of forms, including councils, joint mayor-council and council-manager systems, commissioners, and others. The type of administration varies from community to community and usually depends on the community's size. Many jurisdictions with larger populations, such as the cities of Aiken, North Augusta, and Augusta, have paid professional 
staffs, while smaller communities usually rely on part-time personnel, and the assistance of regional planning agencies.

The region contains one Standard Metropolitan Statistical Area, Augusta, as well as 10 county governments and 38 incorporated areas. The roles of the local governments and their interactions in the region are becoming more important as common regional issues-such as those involving transportation, the environment, communication, technology, and economics-link them closer together. State and federal agencies also interact with the local governments as they administer their programs.

\section{Federal Agencies in the Region}

A number of federal agencies administer programs in the region. Because of its activity at SRS, DOE is the most significant federal presence in the region-and South Carolina's largest employer.

The U.S. Department of Agriculture (USDA) has a major presence in the region. The Agricultural Services Center, the Forest Service (USFS), the Agricultural Stabilization and Conservation Service, the Farmers Home Administration, and the Soil Conservation Service provide significant support for farmers and farm-related activities. The Departments of Commerce, Defense, Health and Human Services, Interior, Justice, Labor, and Transportation also have agencies in the region.

\section{Additional Items of Interest}

\section{Other facts about the region include the following:}

- Sixty-one fire departments provide fire-protection service. Twenty-seven of these are classified as municipal fire departments, but many provide protection to rural areas outside the municipal limits.

- The post-secondary schools available to residents of the study area include five public and four private 4 year colleges, two junior colleges, and five technical schools.

- Ten general hospitals are in operation.

- Nine domestic sanitary landfills are in operation.

- Both electric and natural gas utilities serve the region. The utility companies include a mixture of private, municipal, and rural cooperative companies. SRS has its own electric-generating facility, although it purchases approximately half of its power from the South Carolina Electric \& Gas Company.

\section{History of the CSRA}

Cultural resources embody a set of archaeological, historic, social, political, economic, aesthetic, ethnic, and religious components that, in aggregate, form the cultural heritage of a region. The Central Savannah River Area (CSRA), centered in Augusta, has a rich and varied cultural heritage that began in early prehistory and continues to the present.

The Southeast was occupied for the first time around 9500 B.C. by hunter-gatherers. Available evidence indicates a pattern of long-range seasonal migration associated with the availability of food resources, especially large game. As time passed, settlement patterns were characterized by dispersed hunting and gathering camps centered on strategically located residential villages.

The final prehistoric occupation period was marked by the adoption of intensive agriculture in the region. Associated with this shift in subsistence were changes in settlement and political organization. Populations were concentrated in large villages, often with central temple mounds and defensive stockades; these villages served as religious and political centers. Changes in the political relationships and power among the chiefdoms of the region resulted in the abandonment of the CSRA at approximately A.D. 1450.

No archaeological or historic evidence exists for a Native American occupation in the CSRA between A.D. 1450 and 1690, when exploration and later settlement by European colonists occurred. Economic expansion into the CSRA evolved from initial fur and hide trading to a military and commercial center. The earliest communities in the region were Augusta and New Windsor (now North Augusta), founded in 1736 and 1737, respectively. These formed the commercial center for subsequent economic development in the region.

During the American Revolutionary War, military encounters disrupted the area. After the Revolution, the area grew, and the Augusta area became a key commercial center as the head of navigation on the Savannah River. Large plantations and smaller farms covered the region's countryside during the early 19th century.

Eariy industrial development in the area was marked by the construction of the Augusta Canal between 1845 and 1847 to provide transportation and power for textile mills in the city, and by the founding of the model textile mill and town of Graniteville in Aiken County.

The Civil War disrupted the agrarian economy. Although only one military engagement, the Battle of 
Aiken, occurred in the region, indirect impacts of the war included destruction of the commercial transportation system and a drastic reduction in the labor force, caused by casualties. The regional economy's response to the changes in postwar conditions resulted in major economic shifts. Between 1870 and 1940, the area became a resort for northern industrialists, who wintered in Augusta, North Augusta, and Aiken. Textile mills were restored as a key element in the economy, using the labor force from the decline of small farms.

During the first half of the 20th century, agricultureincluding timber production-continued to be the mainstay of the area' s economy. Construction of the Savannah River Plant (now SRS) during the early 1950s resulted in dramatic restructuring of the economy toward the defense industry and various support services, but agriculture and textiles continued to be important economic factors. 


\section{Chapter 3}

\section{General Site Description}

\section{The Savannah River Site}

The U.S. Government established SRS in 1951 for the production and processing of nuclear materials for national defense requirements. DOE manages SRS as a controlled area with limited public access. Located in south central South Carolina, SRS occupies an area of approximately 310 square miles. The Savannah River forms the site's southwestern boundary for 27 miles on the South Carolina-Georgia border, and the center of SRS is approximately 22.5 miles southeast of Augusta and 19.5 miles south of Aiken, the nearest major population centers. The site includes portions of Aiken, Allendale, and Barnwell counties. Except for site facilities, land cover is a wide variety of natural vegetation types with more than 90 percent in forest land. Adjacent land is used mainly for forest, agricultural, and industrial purposes; industrial uses include a commercial two-unit nuclear reactor power plant, a regional low-level waste repository, and a wide variety of conventional industries.

Open fields and pine and hardwood forests comprise 73 percent of the site; approximately 22 percent is wetlands, streams, and two lakes; and production and support areas, roads, and utility corridors account for 5 percent of the total land area. SRS includes several production, production support, service, research and development, and waste management areas.

In addition to 20 major areas that have been in use at SRS for 40 years, an additional 20 potential industrial sites have been identified and given preliminary evaluations. These range in size up to 2,200 acres. In addition, the entire site is designated as an environmental park used by ecology, forestry, and archaeology groups. The original facility layout of SRS was designed to isolate major radioactive operations near the center of the site. This design created a buffer zone that reduced the risk of accidental exposure to the general public and provided security for the site.

In response to the need for $D O E$ to make the best use of public lands under its control, the USDA's Forest Service (USFS) has conducted a program of forest management at SRS since 1952 through an interagency agreement. In fiscal year 1993, timber cuts brought the federal government $\$ 4,716,780$ for approximately 25 million board feet of lumber. Cutover land is reforested as soon as possible. Approximately 1.2 million pine seedlings were planted on more than 1,969 acres in fiscal year 1994. In addition to producing timber, the forest management program contributes to enhancing environmental diversity, protecting endangered species, conserving other species, providing quality habitats for native wildlife, protecting soil and watershed values, and providing a, healthy forest for environmental research.

Under DOE's National Environmental Research Park Program (NERP), scientific investigators from universities, colleges, and other research organizations use SRS as an outdoor laboratory for the study of the impact of man's activities on the environment.

Deer and hog hunts are held annually at SRS from early November through mid-December to control the resident deer and feral hog populations and to reduce animal-vehicle collisions, which are the greatest cause of on-site accidents. 
This page left blank intentionally 


\section{Chapter 4}

\section{Land-Use Planning at the Savannah River Site}

\section{Background}

The requirements and rationale for land-use planning at SRS include:

- DOE Order 4320.1B requires that all sites have in place a process to plan for and develop real property holdings in support of the site's missions. A master plan implementation process should have a 20-year horizon.

- Resource Conservation and Recovery Act (RCRA) and Comprehensive Environmental Response, Compensation, and Liability Act (CERCLA) guidelines allow for an administered master plan to permit the use of alternate standards for environmental restoration. A commitment to the dedicated use of some lands for indefinite times could have amajor impact on the risk assessments and remediation goals for the site's environmental restoration program.

- Actual and potential siting conflicts for major projects indicated that a comprehensive future-use plan was needed to address the overall intent of safe planning needs. Recent experience proved that a first-come, first-serve allocation system was inadequate for systematic development.

- Historically, the site's natural resource issues have not been addressed adequately for long-term integrated environmental management.

- While the majority of the site's land has been managed in a productive forest management program, a long-term integrated approach is needed to address the emerging objective for ecosystem management to deal with the site's natural resource issues.

- Land-use planning is an open, iterative process. Therefore, to ensure that SRS has the best possible land-use plan, various avenues for on- and off-site stakeholder involvement are included in the process. Inclusion of these diverse points of view should help eliminate areas of disagreement and improve the final product.

Unless alternate plans are put into place, SRS must plan for residential land use. The alternate plans must specify land use based on available information and professional judgment documented in master plans, census projections, and land-use trends in the area. A land-use plan permits introduction of a dedicated land strategy so that DOE may pursue dedication of some SRS land to continuous control for time periods of more than 100 years.

\section{Land-Use Administration}

In 1992, a land-use coordinator was appointed to develop and implement a comprehensive land-use planning program. The coordinator's duties are as follows:

- Define land-use issues identified in existing planning documents and coordinate development of the SRS Land-Use Plan.

- Chair the Land-Use Technical Committee and serve as executive secretary of the Land-UseSteering Committee.

- Review all land-use requests to assure that action can be initiated according to a zoning plan or a variance procedure.

- Work with all on- and off-site stakeholders to ensure that their planning views are considered.

Also in 1992, a Land-Use Steering Committee was selected from WSRC senior management to provide policy direction to land-use planning. The committee's responsibilities, under DOE-SR direction, include

- approving a land-use plan

- setting/changing site land-use priorities

- approving plan changes recommended by the Land-Use Technical Committee

- reviewing issues and approving actions for SRS land use

- acting on use-variance requests with Land-Use Technical Committee recommendations

- providing direction to the land-use coordinator

The Land-Use Steering Committee appointed a Land-Use Technical Committee to support the coordinator in preparing a land-use plan for the site. 
The Land-Use Technical Committee members' duties include

- assisting in the development of the SRS Land-Use Plan

- serving as advocates for their organizations during conflict resolution

- serving as a forum to express competing views on particular issues and parcel usage

- serving as reviewers of site-use proposal variances, as requested by the coordinator

- endorsing and defending-before the Land-Use Steering Committee-changes in the SRS LandUse Plan

After a year of operation, the Land-Use Technical Committee was expanded to include major on-site land users, such as the USFS, SREL, and the University of South Carolina Institute of Archeology and Anthropology. DOE employees serve as observers on the Land-Use Technical Committee. Members of the committee participate in the "Site Use" permitting process and serve as their organizations' points of contact for reviews of planned activities. The Site Use-Site Clearance Program identifies overlap in current and projected land use to ensure that conflicting land uses are addressed prior to project initiation.

\section{Land-Use Plan}

Land-use planning should significantly benefit the siting of proposed major new facilities. Another benefit is expected to be the combination of plans for new facilities with environmental restoration and D\&D activities. There has been an ongoing effort to limit the amount of land that is contaminated and to centralize these areas so they can be considered commercial/industrial CERCLA sites.
Key production facility requirements and proposed large-scale construction projects will require ranking to ensure that areas for these facilities are matched to the attributes of the areas being considered.

\section{Policy Guidelines for Land Use}

Policy guidelines for WSRC land use include the following:

- Protection and safety of employees and the public is the highest concern.

- Site missions will receive priority over other uses.

- Existing infrastructure and facilities shall be considered prior to development of new sites.

- Disturbance to undeveloped land shall be minimized.

- Multiple-use land-use principles shall be stressed.

- Land-use decisions will be compatible with the attributes of the land and adjoining processes.

- Maintenance of plant security shall be of importance.

- When possible, the most cost-effective use will be given priority over other uses.

- Buffer zones shall beconsidered when sitingfacilities.

- A "Restricted Use" program will be followed for special areas (e.g., waste sites).

- Hazardous and radiological facilities will be located as far as possible from environmentally sensitive areas and the SRS boundary.

- When appropriate, joint use with off-site groups will be considered. 


\section{Chapter 5}

\section{Site's Land Use/Mission/Vision}

\section{Emphasis Shifting}

After 40 years of producing nuclear materials for $\mathrm{DOE}$, SRS is shifting its emphasis and resources to waste management and environmental cleanup, with continuing support of the nation's nuclear weapons stockpile.

The elements of SRS's mission are described in the following paragraphs.

\section{Site Mission/Vision}

The mission of SRS is to serve the interests of the nation and surrounding region by applying the site's technical, physical, and human resources to

- protect and improve environmental quality

- support a secure national defense and reduce nuclear danger

- enhance industrial competitiveness and economic development

This must be done in a safe, environmentally sound, socially responsible, and cost-effective manner in partnership with the site's stakeholders. According to DOE Order 4320.1B, "Site Development Planning," the operations office manager shall determine the appropriate level of community involvement in the planning process. The types of public involvement may vary and may be formal or informal.

An overall SRS vision has been established to implement the site's mission. The vision is for SRS to be

- DOE's performance leader in the comprehensive management and disposition of all waste streams and in remediation of contaminated waste sites and groundwater

- a responsible steward of the site's physical and natural resources and ecosystems

- a major contributor to national security by providing tritium and tritium services to the enduring nuclear weapons stockpile

- a significant contributor to the reduction of nuclear danger by being DOE's performance leader in the stabilization, secure storage, and disposition of nuclear materials

- a recognized leader and partner in the development and exchange of applied science and technology to support SRS missions, enhance industrial competitiveness, and serve public needs

\section{Environmental Quality}

SRS is striving to be DOE's performance leader by cost effectively protecting and improving site, regional, and national environmental quality. The site is working to achieve this goal by

- managing and disposing of all SRS wastes

- remediating contaminated SRS environmental sites/groundwater and decontaminating and decommissioning surplus facilities

- developing environmental cleanup and waste disposition technologies through partnerships with government agencies and the private sector

- optimizing the management of site natural and physical resources

\section{National Security}

SRS' national security mission is to be DOE's performance leader in supporting national security and reducing nuclear danger. This mission is accomplished by ensuring an uninterrupted supply of tritium, stabilizing nuclear materials, developing alternatives for nuclear materials disposition, and maintaining key nuclear material core competencies and capabilities for possible future uses.

\section{Applied Technology/Economic Development}

In this time of transition, SRS is working with industry, academia, and government to be a leader and partner in developing and exchanging applied science and technology to support SRS missions, enhance industrial competitiveness, and serve public needs. Site leaders have as a major goal the establishment of a world-class center at SRS for the demonstration and application of innovative waste management and environmental cleanup technologies. 


\section{Current Use}

\section{SRS Employers/Employment}

The total site work force, including subcontractors, is approximately 17,000 employees in the following organizations:

- DOE-SR, which provides overall management and oversight for SRS with 592 employees

- Westinghouse Savannah River Company (WSRC) and Bechtel Savannah River, Inc. (BSRI), which manage and operate SRS for DOE with approximately 15,000 employees, including subcontractors

- Wackenhut Services, Inc. (WSI), which provides and manages the site security force of $846 \mathrm{em}$ ployees

- SREL, which provides site ecological evaluations and research with about 213 employees

- The Savannah River Forest Station (SRFS), an independent unit of the USFS, which manages the site's natural resources with 96 employees.

Other DOE-SR subcontractors-including the U.S. Army Corps of Engineers, Haliburton NUS Environmental Corporation, Science Applications International Corporation, Systematic Management Services, Stone \& Webster and World Computers-total about 396 employees.

Other employers-including the University of South Carolina Institute of Archaeology and Anthropology, the USDA's Soil Conservation Service, and the South Carolina Fish and Wildlife Service-total approximately 25 employees. Figure 5-1 shows the distribution of the SRS population by area.

\section{Condition of Facilities}

SRS contains approximately 2,862 buildings, 234 of which are considered surplus buildings in the Savannah River Inventory and Assessment. An additional 4,800 supporting facilities include nonpermanent buildings and other structures such as bridges, monitoring wells, and pump stations. More than 60 percent of the site's building areas are at least 40 years old. Condition Assessment Surveys have been initiated in fiscal year
1994 as part of the Capital Asset Management Process to better define building conditions and needs.

Currently, 11,220 (66 percent) of the site's employees require office space. Of these, 50 percent are housed in permanent on-site facilities; 30 percent in on-site trailers, and 20 percent in off-site leased space.

Key elements of the SRS infrastructure are as follows:

- General-purpose facilities, including permanent on-site facilities, on-site trailers, and off-site leased office space

- Analytical laboratories

- Railroad network

- Dams, lakes, and ponds

- Electrical and steam generation and supply systems

- Process, domestic, and cooling water systems

- Sanitary waste treatment and disposal systems

- Ecology laboratories

- Roads and bridges

- Other infrastructure, including telecommunications, emergency response, medical, environmental monitoring, fire protection, laundry, constriction shops, and warehouses.

\section{Management of Surṕlus Facilities}

In this "transition" phase of DOE, SRS is working to accomplish the safe, efficient deactivation of surplus facilities to stable conditions-with the most effective cost surveillance and maintenance methods available-in an effort to achieve acceptable end states (i.e., alternative use or permanent disposition). This includes identification and characterization of hazards associated with surplus facilities, working with state and federal regulators, and developing plans for the safe disposition of the facilities. Surplus assets may be made available to private industry, to academia, or to local communities for beneficial uses that would contribute to the economic development and diversification of the local region. The availability of assets would be investigated and evaluated on a case-by-case basis. 


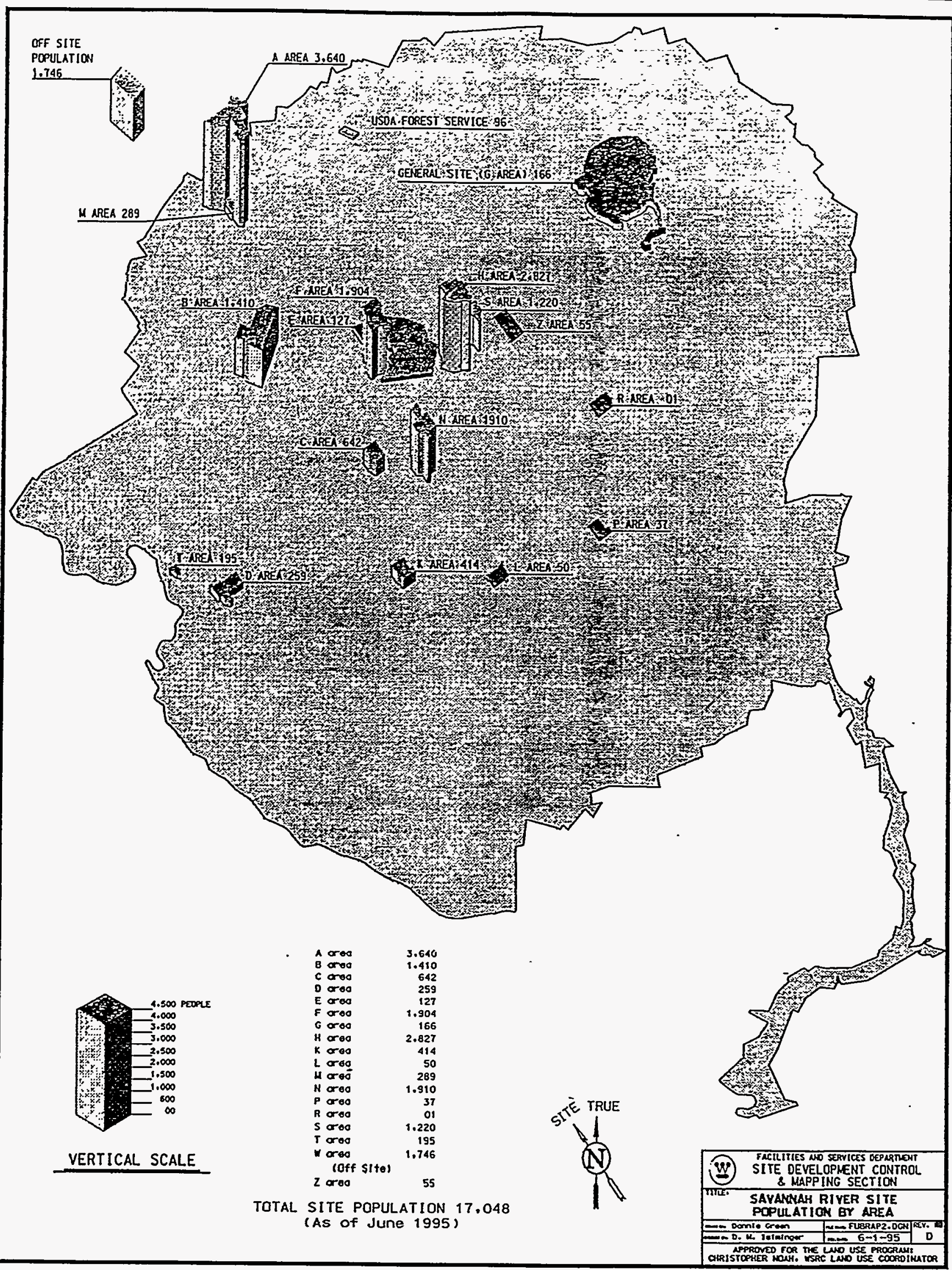

Figure 5-1 
This page left blank intentionally 


\section{Chapter 6}

\section{Land Uses/Land-Use Characteristics/Maps}

\section{In this chapter...}

Administrative/Nonnuclear Facilities $\ldots \ldots \ldots \ldots \ldots \ldots \ldots \ldots \ldots \ldots$ Page 16

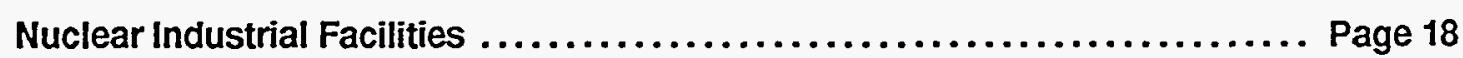

Land Use and Radiological Risk ........................... Page 20

Technology Demonstrations ............................... Page 22

Utilities ............................................. Page 24

Major Highways/Streets/Roads ............................. Page 28

Railroads/Waterbome Transport $\ldots \ldots \ldots \ldots \ldots \ldots \ldots \ldots \ldots \ldots \ldots \ldots$ Page 30

Accessibility of Airports $\ldots \ldots \ldots \ldots \ldots \ldots \ldots \ldots \ldots \ldots \ldots \ldots \ldots \ldots$ Page 32

DOE Set-Aside Program .................................. Page 34

SRS Research and Research Programs ........................ Page 36

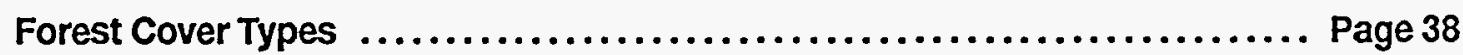

Wildife - Inventory and Management ........................... Page 40

Threatened/Endangered/Sensitive-Species Management ............... Page 42

Fire Management ....................................... Page 44

Archaeological Sensitivity Zones/Cemeteries .................... Page 46

Recreation ............................................... Page 48

Topography/Cadastral ................................... Page 50

Surface Water ............................................. Page 54

Groundwater $\ldots \ldots \ldots \ldots \ldots \ldots \ldots \ldots \ldots \ldots \ldots \ldots \ldots \ldots \ldots \ldots \ldots \ldots \ldots$ Page 56

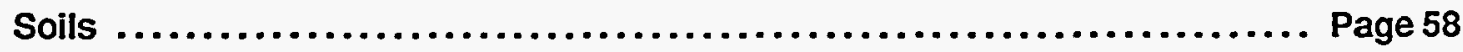

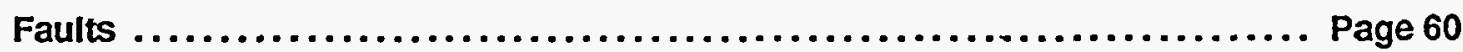

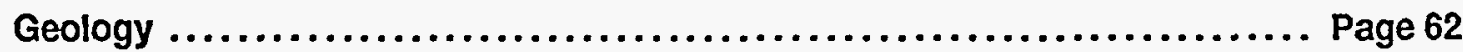

RCRA/CERCLA Waste Units and Site Evaluations .................... Page 64

Surface Water Outfalls .................................... Page 66

Air/Meteorological Monitoring ................................ Page 68

Selection of Sites for Future Missions $\ldots \ldots \ldots \ldots \ldots \ldots \ldots \ldots \ldots \ldots$ Page 70 


\section{Administrative/Nonnuclear Facilities}

\section{Overview/Program Description}

SRS employees are housed in 96 administrative office facilities, 567 administrative trailers, and nine off-site leased administrative facilities. The site's major contractor, WSRC, is responsible for the administration of office facilities and functions.

Office space consists of permanent buildings on site and permanent and temporary office trailers. The program for office space management also encompasses personnel relocation in facilities on and off site. Subcontracts provide janitorial, laundry, food services, pest control, termite treatment and general labor services sitewide to support administrative facilities.

The nonnuclear facilities include Central Shops (N-Area), Heavy Water Area (D-Area), and part of SRTC. Figure 6-1 shows the administrative and nonnuclear facilities.

\section{Purpose/Missions}

\section{Administrative Facilities}

The administrative facilities provide office space, general training, and records storage for SRS personnel to conduct normal operations in support of the site's mission.

A-Area and B-Area are the primary administrative areas. A-Area provides office space for 4,027 employees, and B-Area provides office space for 885 employees. A-Area houses DOE and WSRC senior management and other personnel and is the location of SREL and SRTC. B-Area houses WSRC and WSI personnel.

Administrative facilities also are located in each process area to provide office space for personnel who support the areas' specific functions.

Forty-three percent of the site's office buildings are more than 30 years old, 15 percent are from 10 to 29 years old, and 42 percent are less than 10 years old. Several modular facilities will be proposed during the next five years to facilitate the removal of on-site office trailers. A-Area and B-Area will be primary administrative areas. A sitewide training facility is scheduled for completion in $\mathrm{H}$-Area by fiscal year
1996. Existing administrative space in production areas that are not scheduled for D\&D and that have adequate infrastructure will continue to be utilized to meet overall housing needs. The existing facilities are expected to be wcll-maintained to extend their useful lives.

DOE's most recent priorities for providing administrative facilities are to

- relieve facilities that have serious, irreparable health and safety concerns

- eliminate off-site leased space

- eliminate on-site leased trailers

- relieve compression

\section{Nonnuclear Facilities}

\section{Central Shops (N-Area)}

Central Shops (N-Area) houses construction and craft facilities, such as fabrication and welding shops, and associated materials in support of construction activities. This area also is the primary storage facility for operations and maintenance materials, including supplies and spare parts.

\section{Heavy Water Area (D-Area) -}

D-Area actually is a "dual use" facility in that it has significant nuclear and nonnuclear operations. D-Area contains facilities for supplying heavy water coolant/ moderator to the reactors. Heavy water purification facilities, an analytical laboratory, and a powerhouse are operating in the area. D-Area's mission will be the cleanup and concentration of the existing inventory of heavy water.

\section{Savannah River Technology Center}

SRTC conducts research, development, and technical support activities. Laboratory operations are conducted in the Technical Area (700) and the TNX Prototype Testing Area (600). SRTC also has nuclear facilities within the Technical Area. As an incentive to industry 1) to locate or expand operations within the local region and 2) to enhance technology transfer, a plan will be implemented to establish user facilities, thus serving a dual-use function that supports the SRS mission but is available to the private sector. 


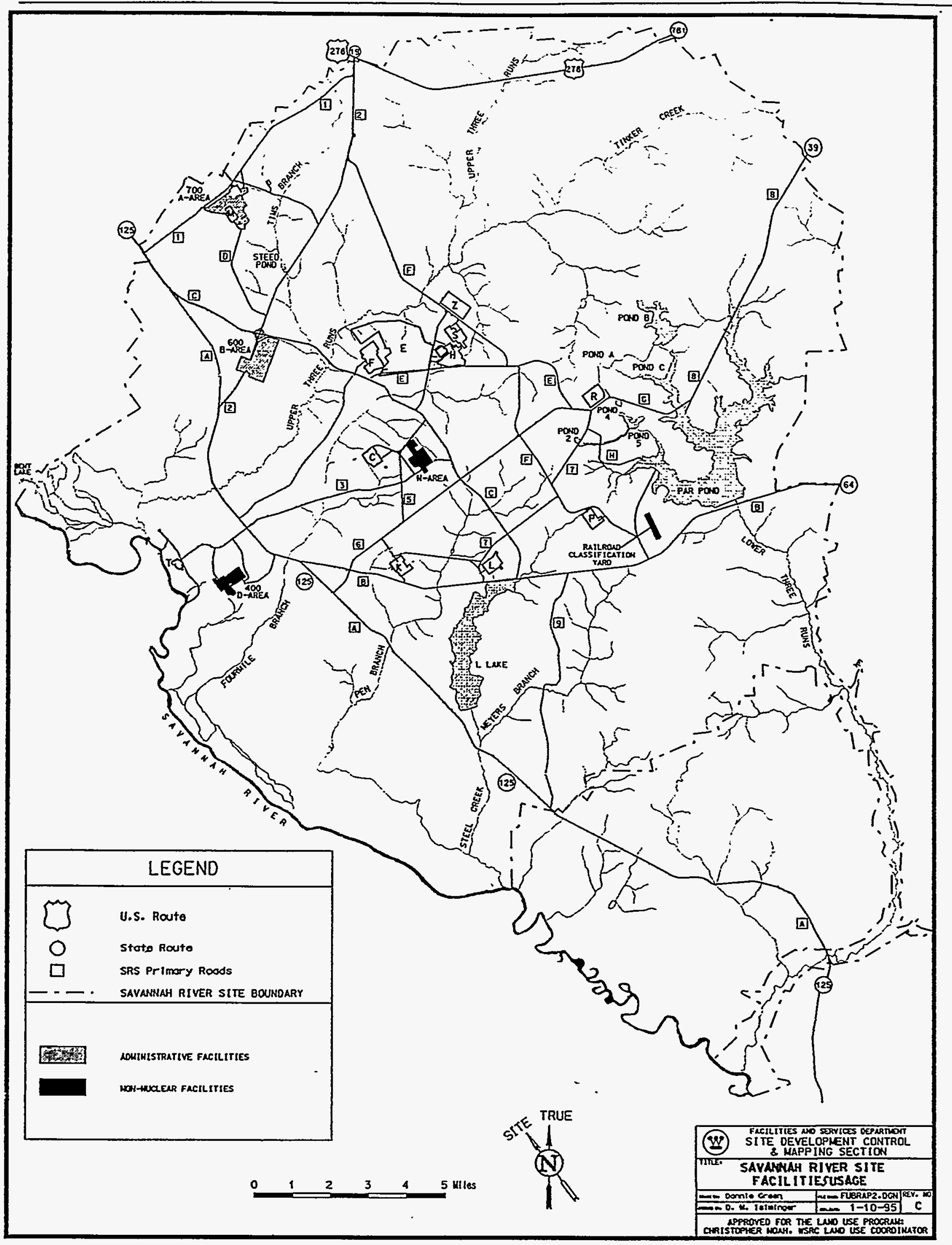

Figure 6-1 


\section{Nuclear Industrial Facilities}

\section{Overview/Program Description}

The nuclear industrial facilities at SRS are owned by DOE and operated and maintained by WSRC (figure 6-2). The purpose of these facilities is to provide stabilized, secure storage and disposition of nuclear materials. Because a number of these facilities are no longer in use, SRS is developing D\&D plans for the facilities' final disposition. These plans will include the numbers and locations of buildings, cost estimates, and health and safety considerations.

\section{Purpose/Missions}

\section{Fuel/Target Fabrication (300 Area)}

Metallurgical/foundry facilities for fabricating reactor fuel and target elements for SRS reactors are located in the 300 Area. An orderly phaseout of all production activities for reactor fuel and target manufacturing is occurring. Materials in the area are being processed for shipment to permanent storage sites or declared excess and disposed. Subsequently, the retired facilities will be transferred to the Facilities Transition Program and placed in a surveillance and maintenance mode pending D\&D or reuse by commercial firms.

\section{Nuclear Production Reactors (100 Area)}

Five reactors for nuclear material production originally were built at SRS. All five reactors $-C, K, L, P$, and $\mathrm{R}$-are now classified as surplus facilities. Fuel storage basins in L-Reactor and P-Reactor contain irradiated fuel and targets awaiting a decision on future disposition. K-Reactor is in "cold standby." Future production of new tritium by a new reactor or accelerator is the subject of ongoing DOE studies.

\section{Nuclear Materials Processing Facilities (200 Area)}

The processing, stabilization, separation, and recovery of nuclear materials are performed in two main operating areas, 200-F and 200-H. Each has 1) a large shielded "canyon" building for processing irradiated materials, 2) glove box facilities for product finishing and plutonium residue processing, and 3) associated support facilities. In addition, F-Area contains an analytical laboratory, the Plutonium Metallurgical Building, and the Naval Fuel Facility (currently in standby). H-Area contains the Receiving Basin for Offsite Fuel, which provides interim cooled storage for off-site spent fuels.

The nuclear materials management mission includes stabilization, secure storage, and disposition of the large quantities and various types of nuclear materials at SRS, as follows:
- Stabilize SRS nuclear materials for safe, secure storage and eventual disposition. Many activities are contingent upon the completion of pending $\mathrm{Na}$ tional Environmental Policy Act (NEPA) actions.

- As required to implement preferred alternatives identified through an ongoing NEPA process, process or stabilize existing inventories of nuclear materials, including unstable spent fuels, to forms suitable for safe, secure storage for eventual disposition as waste or as usable materials (F-Area/HArea).

- Receive and store off-site spent nuclear fuels contingent upon completion of appropriate NEPA requirements.

\section{Tritium Facilities}

The tritium facilities, located in H-Area, extracted tritium from irradiated targets and unloaded returned reservoirs, purified recycled tritium, and reloaded reservoirs. The tritium recycling mission, modified by anticipated program changes, will continue at SRS. Activities include recycling of weapon components for the active stockpile and extraction of tritium from remaining irradiated targets. In the long term, SRS will continue to recycle tritium and to add new nonnuclear missions.

\section{Waste Management Facilities}

High-level waste storage tanks are located in F-Area and H-Area. In S-Area, the Defense Waste Processing Facility, which is undergoing startup testing, will immobilize the high-activity portion of this waste in glass. The Saltstone Facility, already in operation, solidifies the low-level fraction in grout (saltcrete) in Z-Area. The Effluent Treatment Facility (ETF) for low-activity liquid wastes also is located in H-Area.

\section{Solid Waste Disposal Facility (SWDF)}

The SWDF is a centrally located, 195-acre complex in G-Area and E-Area that stores and disposes of radioactive solid wastes. Facilities include the Low Level Radioactive Waste Disposal Facility, Transuranic Waste Storage Pads, and the Mixed Waste Storage Buildings.

\section{Heavy Water Area (D-Area)}

As noted on page 16, D-Area is a "dual use" facility with both nuclear and nonnuclear operations. 


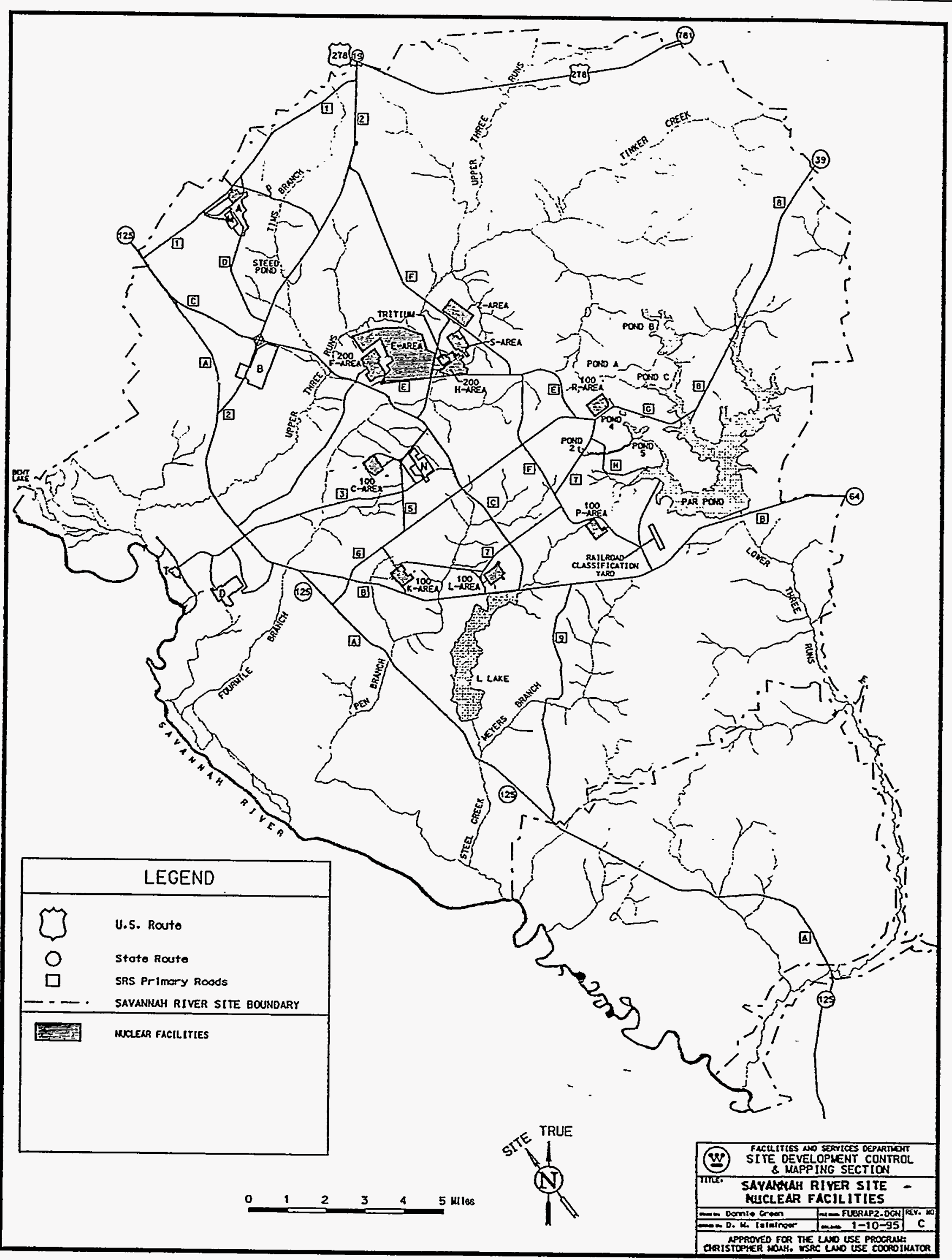

Figure 6-2 


\section{Land Use and Radiological Risk}

\section{Overview/Program Description}

SRS nuclear facilities contain large quantities of radioactive materials that could impact the health and well-being of site employees and the general public in the event of a release during an accident.

Many safety features and operating procedures are in place to prevent such accidents, and additional safety features are provided to reduce the impact of an accident, should one occur. Examples of these safety features include

- multiple-containment vessels and structures

- structures that withstand earthquakes, hurricanes, tomadoes, and other natural phenomena

- filter systems to reduce the number of releases following an accident

- systems to prevent fires and explosions

- backup and emergency electrical power systems

The impact and risks from potential accidents at SRS nuclear facilities are analyzed in formal "Safety Analysis Reports" and other safety-evaluation reports. These reports describe each facility and its operations, with special emphasis on safety features. The reports also consider all possible accidents and analyze the risk to site workers and the general public.

Significant discussions have been held between governmental agencies, contractors, and private individuals on the subject of risk acceptance. To date, these discussions have not produced a single consensus set of guidelines; however, they have resulted in a growing technical consensus in some areas. The rules, regulations, orders, and standards of DOE and the NRC are the basis for the risk acceptance guideline used in this report (especially "DOE-STD-3005-YR-Pro-
posed-Evaluation Guidelines for Accident Analysis and Safety Structures, Systems, and Components," February 1994). This guideline is employed to provide perspective and context for the accident-dose evaluations.

The potential accident impact and risk to the general public from all the SRS nuclear facilities meet this guideline. Meeting the risk guideline means that the radiation dose a person could receive at the site boundary, in the unlikely event of an accident, would be less than the dose allowed by the guideline.

\section{Purpose/Mission}

Figure 6-3 shows the areas of SRS where the radiological risk guideline for radiation dose to the general public is satisfied and where it is not. In other words, the map indicates the areas outside of which a person could be located during a potential accident and receive a radiological dose less than that specified by the guideline. The map shows that a person located at the site boundary during an accident could receive a dose at or below that permitted by the guideline. It also shows that the dose is within guideline limits over most of the site.

The map was generated from the safety documentation for each of the SRS nuclear facilities. The worst airborne release accident from each facility was compared to the risk guideline. Also evaluated were accidents affecting multiple facilities that could be caused by the same event. At SRS, the only common event of significance is an earthquake. Airborne releases were evaluated because they are the most likely to impact the public following an accident. The impact of accidents that could release radioactivity to the Savannah River would be significantly reduced by the prompt emergency response of site personnel, and therefore would cause lower radiation doses. 


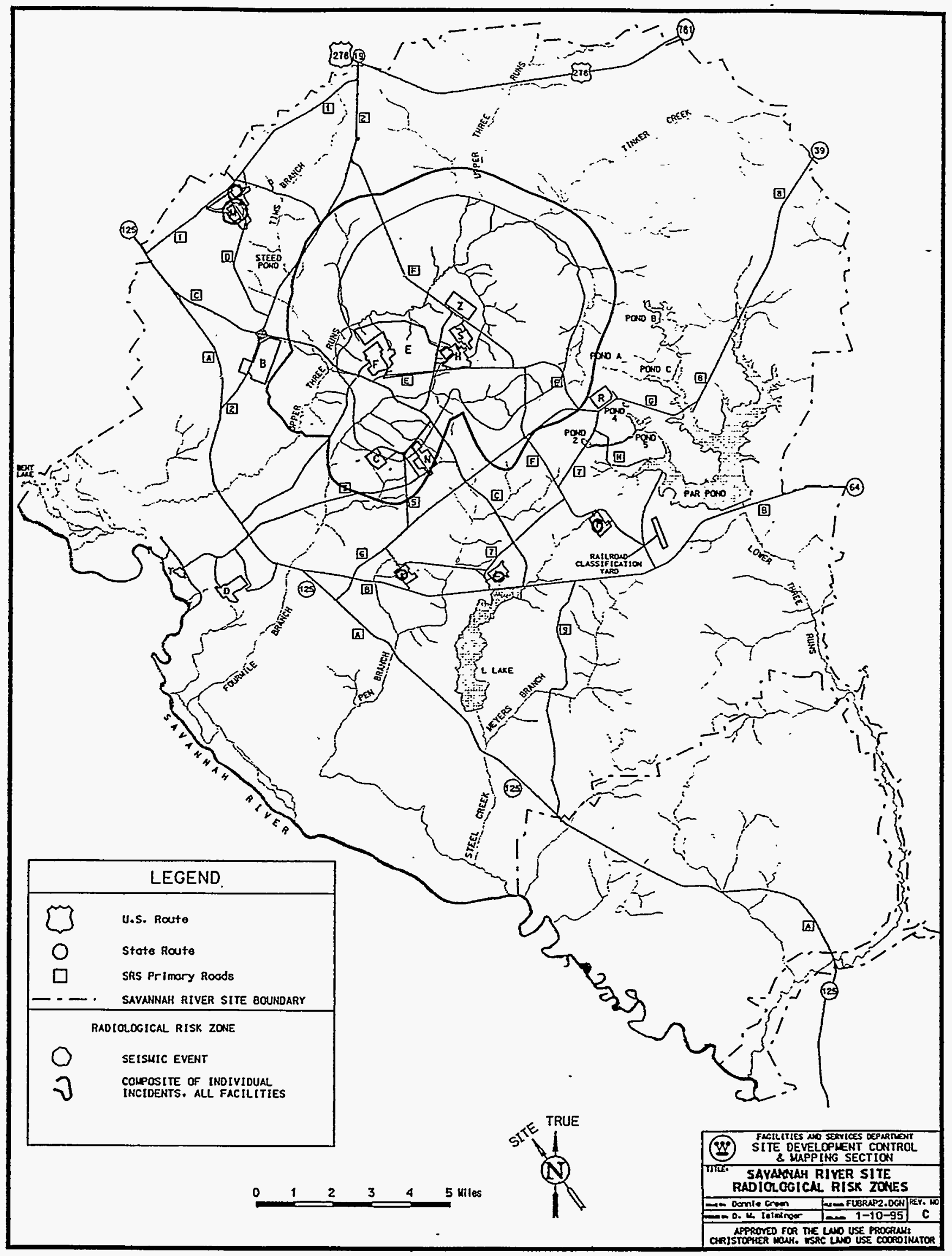

Figure 6-3 


\section{Technology Demonstrations}

\section{Overview/Program Description}

SRTC conducts demonstrations of SRS environmental remediation technologies (figure 6-4). These demonstrations focus primarily on the remediation of groundwater and soil contamination, with an emphasis on the remediation of organic contaminants, such as degreasing solvents and petroleum.

\section{Purpose/Missions}

A major focus of these efforts has been the remediation of solvent-contaminated groundwater in the areas of SRS where such solvents historically were released to surface impoundments or leaked from buried pipes and migrated into the groundwater. An integrated demonstration evaluation of a wide variety of physical and biological remediation technologies recently was completed in the A-Area and M-Area. As a followup, a program evaluating remediation technologies for dense nonaqueous phase liquid solvents is being initiated.

Remediation technology demonstrations are being conducted at TNX and D Area. These demonstrations include remediation of solvent-contaminated groundwater and petroleum-contaminated soils.

Demonstrations of wetland remediation technologies are being conducted at the SRS by WSRC, SRFS, and SREL. Lost Lake, a Carolina bay in M-Area, is being remediated following a RCRA remedial action. Wetland restoration technologies are also being tested in Pen Branch, a stream-swamp drainage impacted by historical reactor discharges. Wetland restoration techniques are being evaluated at other Carolina bay and wetland areas around SRS. 


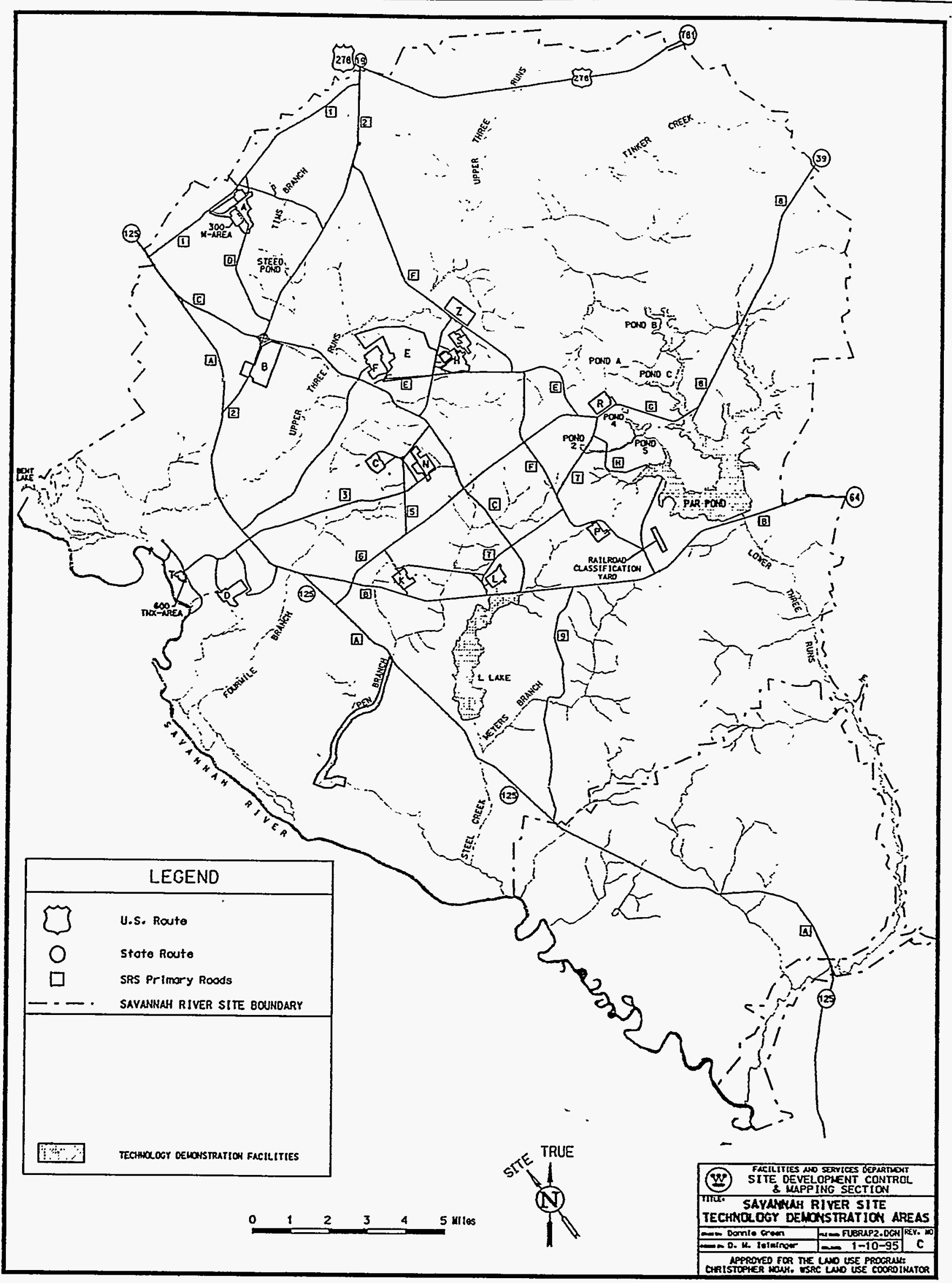

Figure 6-4 


\section{Utilities}

\section{Overview/Program Description}

The Power Operations Department oversees facilities that provide electricity, steam, river cooling water, domestic water, service water, and sanitary waste treatment (figure 6-5). Steam and electricity are produced in the coal-fired cogeneration plant, while steam only (for $\mathrm{K}$-Area) is supplied by the operation of three diesel fuel-fired boilers within the area. Reactor cooling water is pumped from the Savannah River through a system of underground pipes into the 186 basins located throughout the reactor areas. Power Operations controls the pumping rate and the basin level. Domestic and service water are supplied through a deep-well pump system within the site's areas, and sanitary waste is treated in 20 plants located throughout the site. Power Operations personnel monitor and sample all sanitary outfalls for National Pollutant Discharge Elimination System (NPDES) permit compliance. They also operate

- chilled water systems for air conditioning and process ventilation

- process cooling water systems and air compressors for instrument air service

- process air service

- plant air service

- the large exhaust fan facilities in the canyon areas

\section{Purpose/Missions}

\section{Domestic Water}

SRS has 28 domestic water systems that provide water for drinking, washing, showering, and lavatories. Twenty-seven water systems are supplied with treated groundwater from site production wells.

\section{Earthen Dams}

SRS has 13 structures that are considered dams by definition. Built of earthen materials, they were constructed to create cooling reservoirs and ash containment basins, or were original (pre-SRS) farm ponds. All the dams are located in D-Area, G-Area ${ }^{2}$, or H-Area. The largest dam is at Par Pond, a 2,640-acre reservoir on Lower Three Runs Creek. The reservoir's purpose was to serve as a recirculating cooling basin for R-Reactor and P-Reactor, which no longer are operating.

2 The area of the site outside the facilities and administrative areas.
The Earthen Dam Safety Program, established in 1990 is responsible for maintaining the structural integrity of the dams while minimizing environmental impacts.

\section{Electricity}

The SRS electric grid is a 115-kilovolt ( $\mathrm{kV}$ ) system in a ring arrangement that supplies power to operating areas, water pumping stations, administrative areas, and a number of independent and support function areas. Three commercial "tie lines" connect with the SRS grid. The $115-\mathrm{kV}$ system includes about 100 miles of transmission lines. Power normally is supplied to the SRS grid by South Carolina Electric \& Gas Company. Seven on-site, coal-fired turbogenerators supply a fraction of the on-site load and limited reserve power.

\section{Sanitary Wastewater}

SRS has 20 operating package-type sanitary wastewater treatment plants in 13 site areas. Because of changing environmental compliance requirements, sitewide area population shifts, and existing plant optimum capacity limits, systems in the following areas are now considered inadequate: $A, B, C, F, H, N$, $F$, and $S$. The Central Sanitary Wastewater Treatment facility is currently under construction to replace these systems. Total design capacity is rated at 1.05 million gallons per day.

\section{Steam}

Building and process steam is provided to various areas across the site using the steam distribution system. The interarea steam distribution system consists of more than 20 miles of interarea steam piping, ranging in diameter from 6 inches to 24 inches. The D-Area Powerhouse is the primary source of process steam on site. Supplemental steam is produced by the H-Area powerhouse. Steam lines operate between other areas to provide an alternate source of steam in case of boiler failure and to provide a supplemental source between areas for peak demands.

\section{River Water}

The river water system provides cooling water for various process uses, primarily reactor operations, from the Savannah River and the Par Pond reservoir. This system consists of four pumping stations-three on the river and one on Par Pond. SRS has a network consisting of more than 50 miles of underground piping, ranging in diameter from 48 inches to 84 inches. 


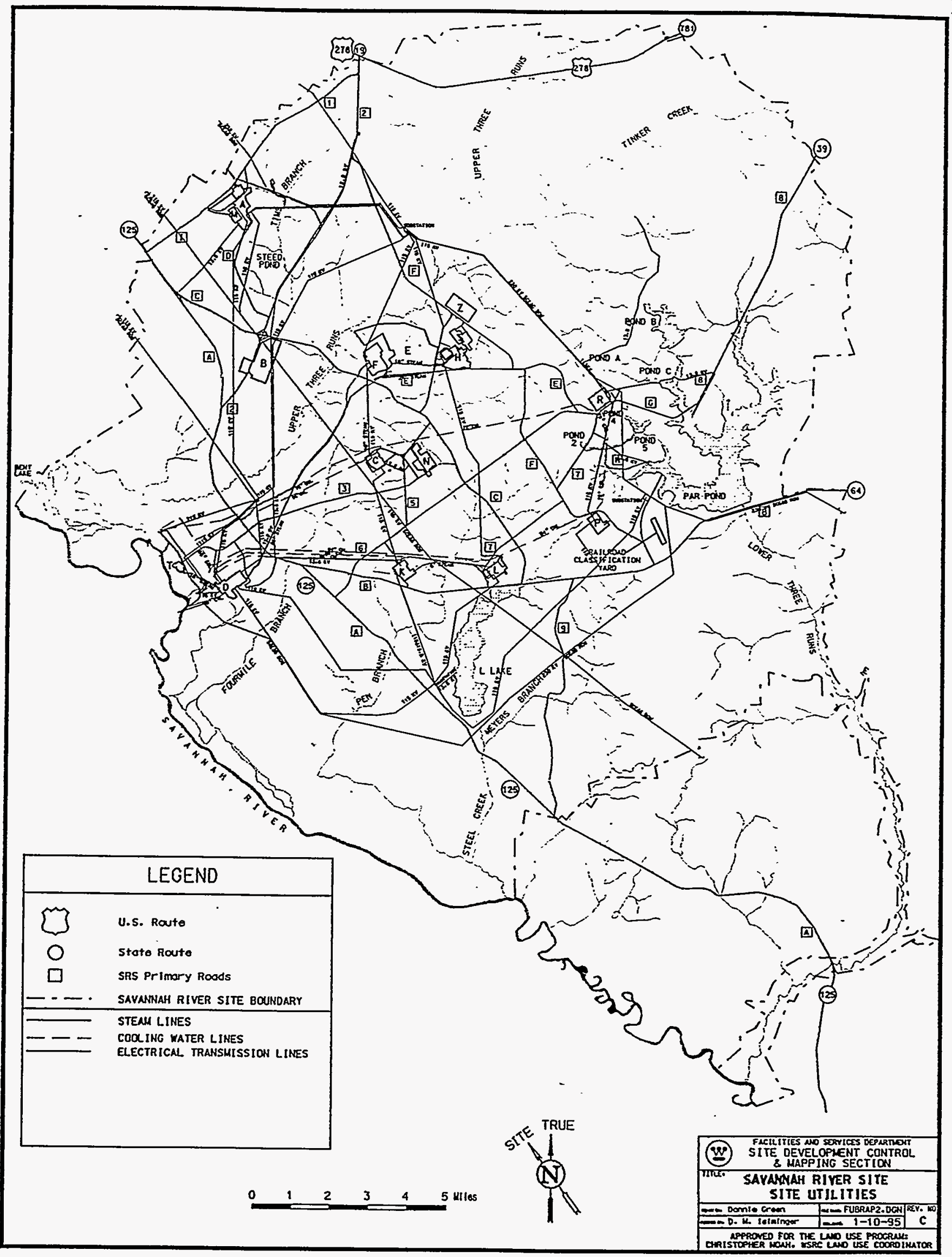

Figure 6-5 


\section{Communications}

Infrastructure and land use for the telecommunications network support the integration of voice and data services on and off site (figure 6-6). These resources provide efficient access to site, DOE, national, and global communications. The current Replacement Telecommunications System project will involve a total system upgrade in fiscal year 1995. The enhancements are essential to meeting the site's voice and data transfer demands. Information Resource Management infrastructure projects, Network Operations, and Replacement Telecommunications System sections share responsibility for all project and operational aspects of the site's telecommunications network. Areas and buildings are interconnected with intra- and interarea cable and fiber facilities. 


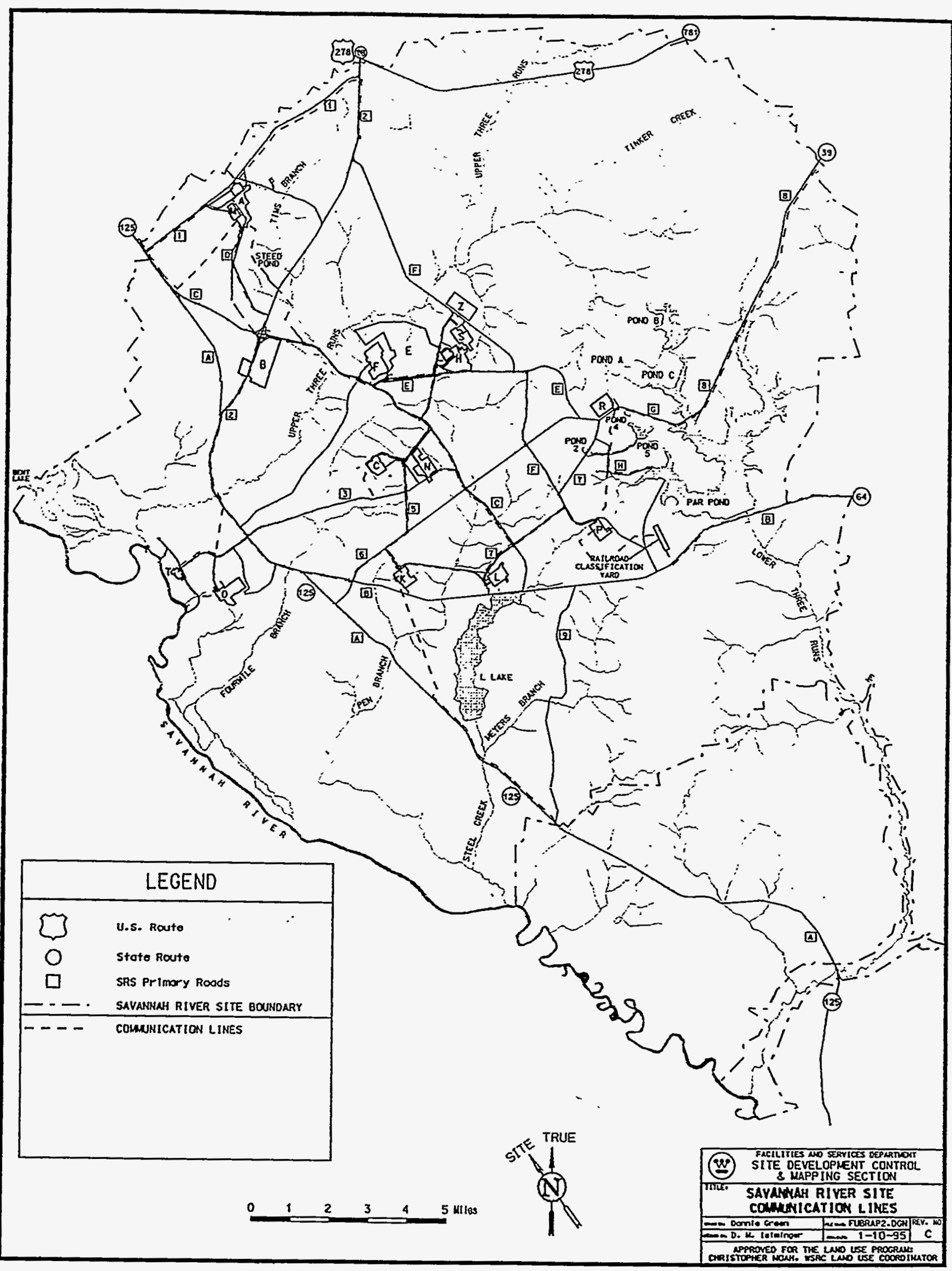

Figure $6-6$ 


\section{Major Highways/Streets/Roads}

\section{Overview/Program Description}

SRS has an internal road system consisting of approximately 140 miles of primary roads (figure 6-7), 1200 miles of secondary roads, and 1,000 miles of USFS and deer hunt trails. The SRS road system accommodates traffic volumes resulting from commuters and a fleet of government vehicles. SRS road maintenance (pothole patching, resurfacing, striping, inclement weather servicing, etc.) is performed by WSRC. All primary roads on and leading to the site are "all-weather" roads, which means they are passable during all weather conditions. During the infrequent periods of ice or snow, the roads are made passable by plowing, spreading sand, etc.

Off-site access to SRS is provided by four South Carolina primary roads: SC 125, the main access route from the Augusta/North Augusta/Allendale region; SC 19, which provides access to SRS from the Aiken/New Ellenton region; SC 39, which provides access from the Williston region; and SC 64, which provides access from the Barnwell region (figure 6-9).

South Carolina is serviced by five U.S. primary routes: $\mathrm{I}-20, \mathrm{I}-95, \mathrm{I}-26, \mathrm{I}-85$, and I-77. The nearest to SRS is I -20 , approximately 30 miles from the center of the site.

In addition, U.S. Highway 1 passes through Aiken and Augusta and U.S. Highway 301 passes through Allendale. Both extend to within 20 miles of the center of the site.

\section{Purpose/Missions}

\section{Load Characteristics}

Major SRS bridges at one time were rated to carry 200-ton loads under special conditions, but because of advanced age, the only bridge now capable of supporting such a load is the 1987 replacement bridge on Road 3. The remainder of the primary bridges are scheduled for replacement beginning in 1994. As is standard with over-the-road shipments, heavy loads to be carried on state-maintained and SRS roads require permitting, as well as preplanned route approval from the State of South Carolina and the SRS organization responsible for the roads.

\section{Public Access Control}

South Carolina primary routes provide uninhibited public access to the SRS perimeter, however, access to SRS interior roads is controlled by security barricades at entrances on major roads and locked gates on secondary roads. All occupants of a vehicle must possess a security badge issued by SRS to enter the site perimeter. SRS secondary roads near the perimeter are controlled with locked "cattle gates" and require a perimeter security gate key for entry. In addition, the SRS security contractor, Wackenhut Services, Inc., conducts regular patrols around the site perimeter.

Three roads on SRS property are available for public use: SRS Road 1, SC 125, and U.S. 278. SRS Road 1 connects SC 125 to SC 19 and services the Administrative Area parking lots and SRS Road 1-A. SRS Road 1 does not have controlled entry, but access from Road 1-A to the remainder of SRS is controlled with security barricades. U.S. 278 traverses a small northern corner of SRS. There are no primary entrance routes along this roadway and SRS secondary roads are secured with locked gates. The third public access route is SC 125 , which runs northwest to southeast along the western edge of SRS. Travelers on this road, which connects North Augusta and Allendale, are not required to stop at the northern and southern security checkpoints. However, security barricades at site boundaries can be closed during emergency situations. In addition, main entrance routes along SC 125 within SRS (SRS Roads B, 2, 3, and 6) are controlled with manned barricades. 


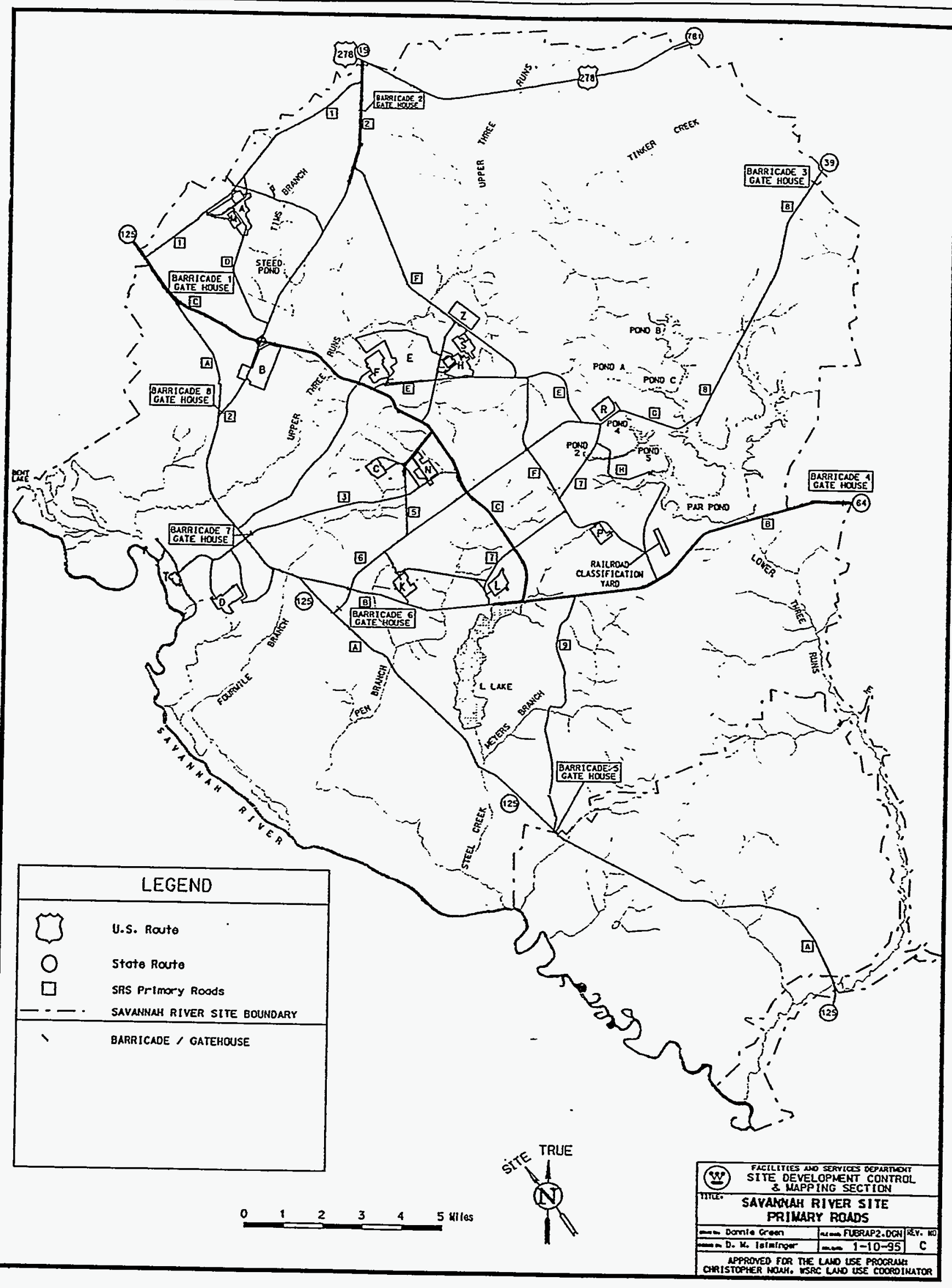

Figure 6-7 


\section{Railroads/Waterborne Transport}

\section{Overview/Program Description}

SRS maintains a railroad system that is adequately designed and maintained to support current and proposed facilities. The system consists of approximately 60 miles of track situated to provide access to all major operations facilities located within the site (figure 6-8). SRS rail-rolling stock consists of locomotives and rail cars to support on-site rail moves. A full-service subcontractor maintains all rails, cross ties, ballasts, and subsurfaces to meet or exceed federal transportation guidelines. No tunnels or underpasses restrict the transportation of tall or wide loads.

Materials and products transported by rail to or from SRS are shipped by the Norfolk Southern Corporation and CSX Transportation, both of which have access throughout the United States, Canada, and Mexico.

The SRS rail system is configured-and has been used routinely-to efficiently provide on-site transportation of such items as irradiated fuel, high-level contaminated equipment and waste materials, construction materials and equipment, environmental products, and bulk materials, such as coal, sand, gravel, etc.

Access to the rail system is controlled by a security gate and derail system. Off-site rail deliveries are brought to the railroad classification yard for transfer to the SRS rail system. Security gates remain locked during off-shift hours.

SRS has boundary access to the Savannah River, which has been used successfully to transport large, heavy loads, particularly during initial site construction and then, with less frequency, up until 1979. Prior to 1979, the U.S. Army Corps of Engineers maintained the river with a 9-foot channel. While no regular river shipments have been made since that year, special waterborne shipments were made to Augusta and SRS as recently as August 1992. 


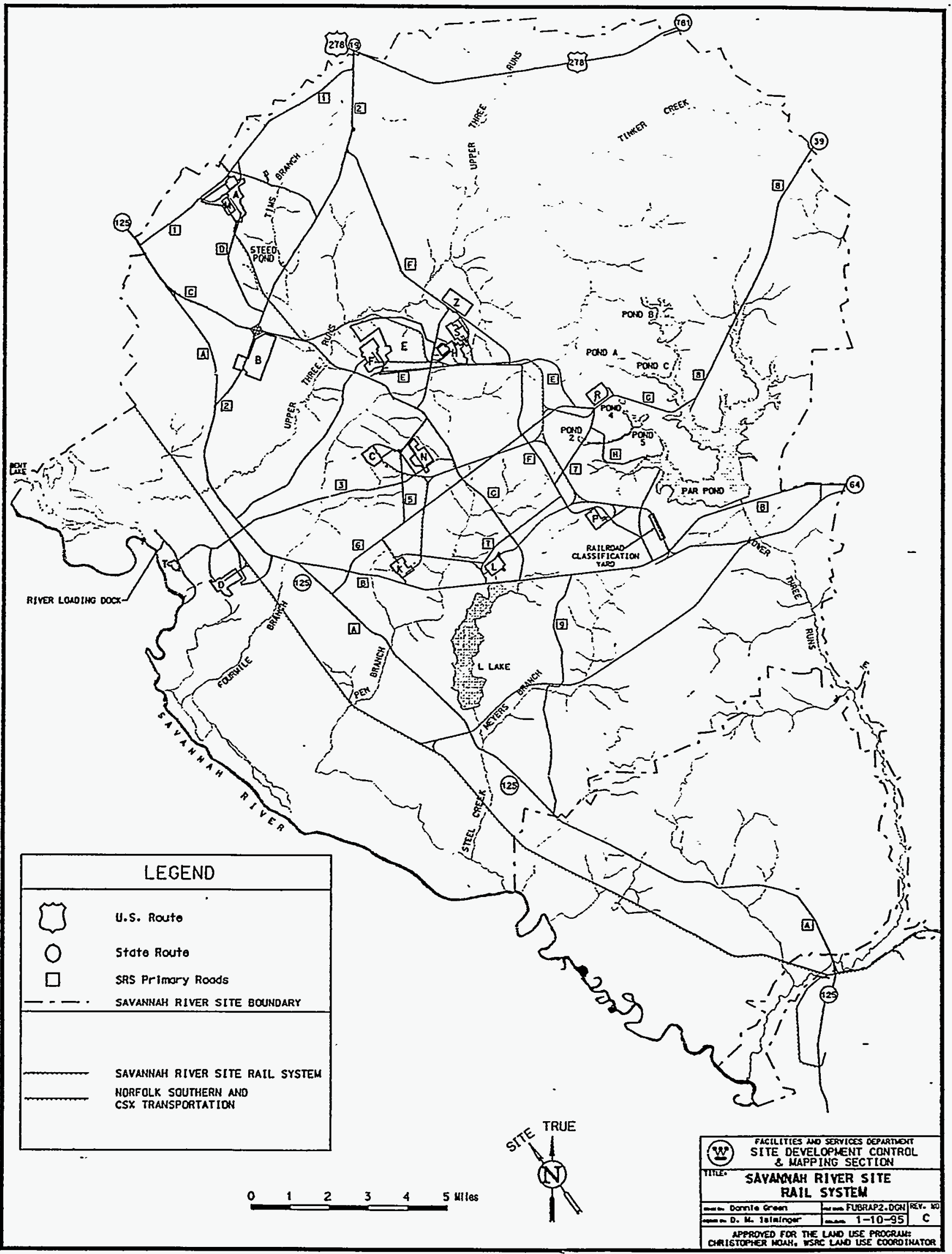

Figure 6-8 


\section{Accessibility of Airports}

\section{Overview/Program Description}

Commuter and jet service to major U.S. cities is provided by two commercial airports in the vicinity of SRS (figure 6-9). Bush Field in Augusta is approximately 21 miles from the site; Columbia Metro airport in Columbia, South Carolina, is approximately 56 miles away. Both can handle a steady flow of SRS visitors.

\section{Purpose/Missions}

Both airports provide air cargo service, including the capability of shipping and receiving major nonnuclear weapon components. Bush Field can accommodate a variety of cargo airplanes, including the $\mathrm{C}-5 \mathrm{~A}$, with a capacity greater that 400,000 pounds. Columbia Metro also is able to facilitate the easy maneuvering of large, wide-bodied aircraft, such as the C-5A. 


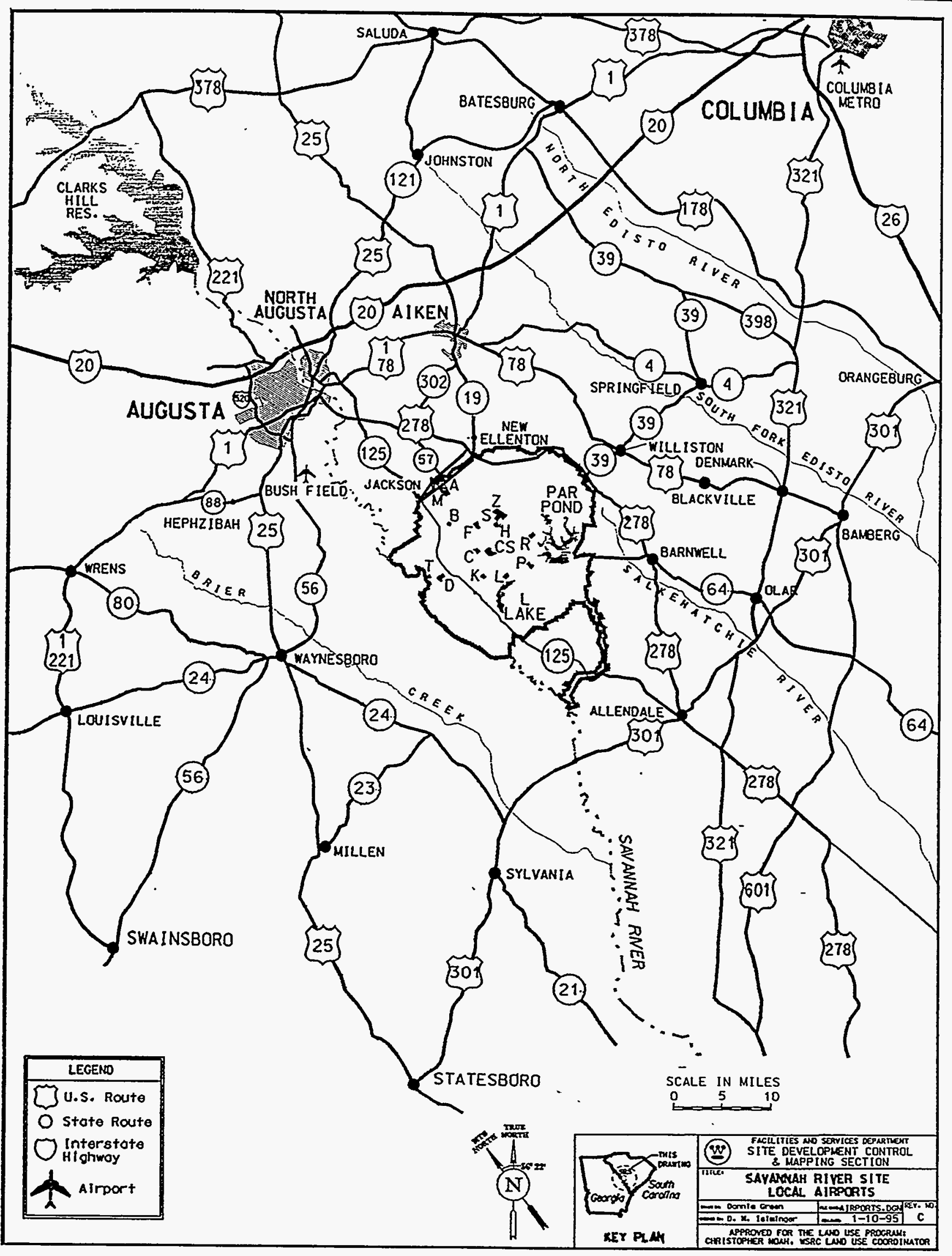

Figure 6-9 


\section{DOE Set-Aside Program}

\section{Overview/Program Description}

In 1967, SREL selected 10 reserve areas that represented the major vegetational communities at SRS. In 1968, these areas were set aside by the manager of DOE-SR to represent and protect examples of the major plant communities and habitat types within the site's boundaries. These DOE Research Set-Aside Areas, protected from public access, forest management, and most routine site activities, offered locations for long-term ecological research, as well as "control" sites for collecting data to compare with other areas of SRS that could be impacted in some way by site operations. In 1972 SRS was designated as the nation's first National Environmental Research Park (NERP). DOE's NERP Program is dedicated to the study of the interaction of man-managed environments with natural systems. In 1989, SREL proposed that 20 additional DOE Research Set-Aside Areas be added to the program, for a total of 30 "set-asides" totaling 14,230 acres, or 7 percent of the land at SRS.

\section{Purpose/Missions}

The purpose of the DOE Set-Aside Program is to establish and maintain SRS lands that represent unique and natural habitats of the region, to protect rare, threatened, and endangered biota that inhabit these areas, and to provide sites conducive to long-term ecological research. Also, these relatively undisturbed natural areas serve as control sites for evaluating impacts from SRS operations and intensive forest management activities. Through the Set-Aside Program, the protection and preservation of these areas not only will aid in sustaining a high degree of biological diversity on the site, but also will fulfill the objectives of DOE's NERP Program.

The objectives of the Set-Aside Program are to

- establish, mark, and maintain the boundaries of the set-asides

- document the floral and faunal communities within the set-asides to establish baseline information that will complement SRS's Integrated Biodiversity Research Program

- conduct research within the set-asides to better understand the ecology of these areas

- take advantage of the set-asides as relatively undisturbed, unimpacted reference areas for detecting the potential impacts of SRS site operations

SREL serves as custodian for the 30 set-asides and provides day-to-day administration of the DOE Set-Aside Program. The program receives guidance and technical advice from the Set-Aside Task Group, which was established in 1992 under the auspices of the Natural Resources Coordinating Committee to help DOE manage the natural resources of SRS. The task group ensures that the Set-Aside Program meets the objectives of the Set-Aside Protection and Management plan, which stipulates that set-asides

- are for research, not for intensive management objectives

- should receive as little management as possible

- should be protected to remain as natural as possible, with little or no human influence

- are primarily for nonmanipulative research, with no research being conducted in a set-aside that would alter its long-term value

SREL has developed a computer-based geographic information system (GIS) data layer delineating the boundaries of the 30 set-aside areas (figure 6-10). This GIS layer is used on site to ensure that set-aside boundary lines are available for consideration by SRS groups making land management decisions. A variety of ecological research projects are under way within set-aside areas, which also have significant importance as "control" or unimpacted sites for other SRS groups involved in monitoring the ecological effects of site operations. Continued research within set-aside areas will provide valuable baseline information to aid DOE in the operation, restoration, and remediation of SRS facilities. 


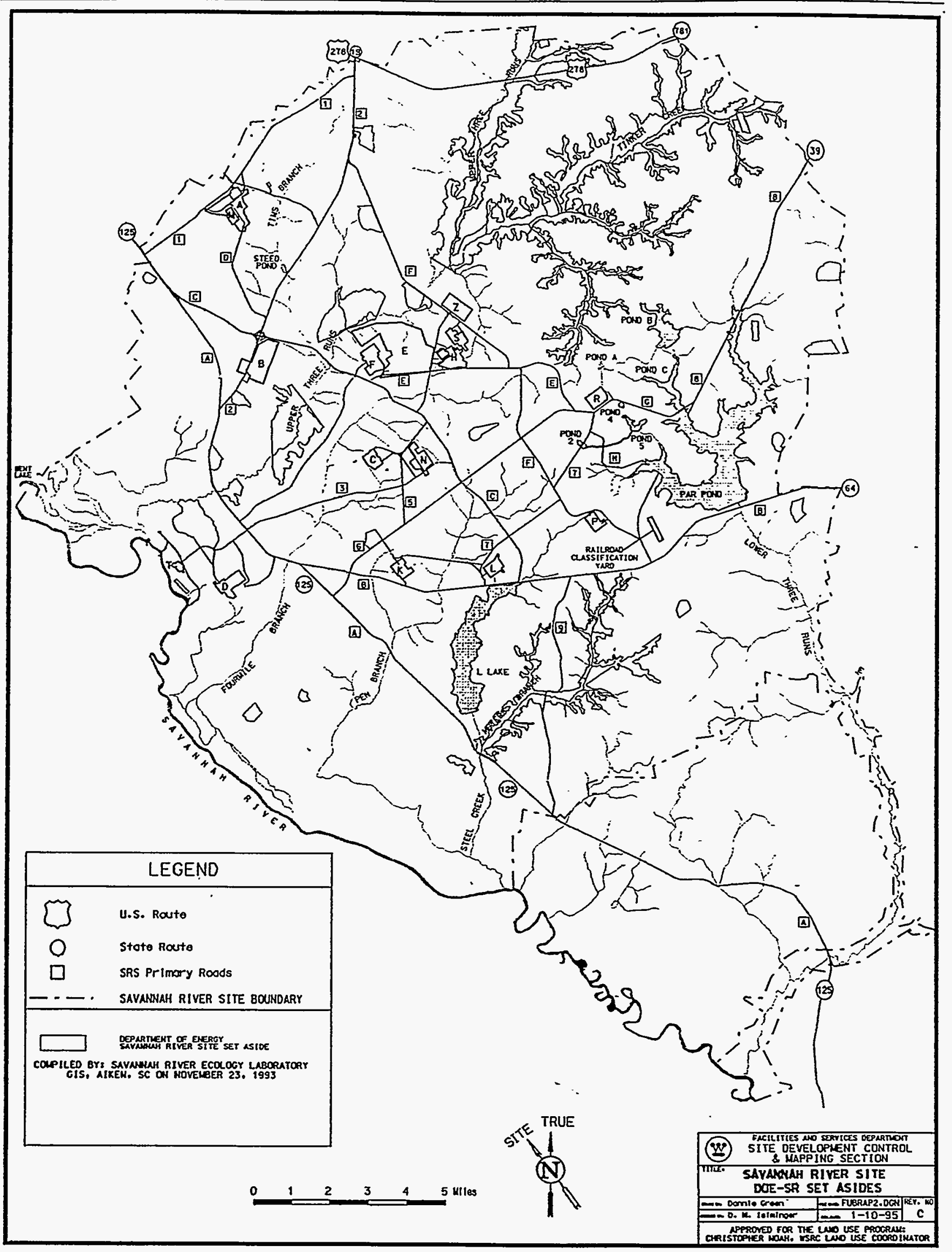

Figure 6-10 


\section{SRS Research and Research Programs}

\section{Overview/Program Description}

In addition to the NERP Program, there are other major research programs at SRS (figure 6-11). While 12 universities and other research organizations perform research at SRS, most is conducted by SRTC, SREL, and SRFS.

\section{Purpose/Missions}

\section{SRTC Research}

SRTC's Ecology Group conducts research and monitoring activities in a variety of locations and habitats on the SRS. Two wetland restoration activities are under way near M-Area and in Pen Branch. The M-Area/Lost Lake restoration involves reconstruction of a wetland habitat following the cleanup of a Carolina Bay under RCRA. The Pen Branch project involves restoration of native wetland vegetation following damage from K-Reactor liquid thermal discharges. Both restorations are collaborative efforts among WSRC, SRTC, SREL, and SRFS. Monitoring of the restorations involves WSRC, SRTC, SRFS and South Carolina Universities Research and Education Foundation (SCUREF) personnel.

Other Ecology Group field research programs include reestablishment of native vegetation in a wetland damaged by groundwater outcropping from the F-Area and $\mathrm{H}$-Area seepage basins. Further research involves the documentation of small mammal populations utilizing four different SRS habitat types; the emphasis of this research is on utilization by subterranean species that could burrow into buried waste.

SRTC's Groundwater. Group conducts extensive research on remediation technologies for groundwater, emphasizing the remediation of organic contaminants. The most extensive field research is being conducted in A-Area, M Area, and TNX Area, where techniques ranging from air stripping to soil heating to microbiological enhancement are being tested alone and in combination to accelerate the remediation of contaminated groundwater. Other methodologies under evaluation include the testing of innovative and cost-effective techniques for detection and monitoring of soil and groundwater contamination.

\section{SREL Research}

SREL personnel conduct independent ecological research at the SRS. Faculty, staff, and students in the laboratory's three research divisions conduct research on diversity, physiology, and genetics of deer, waterfowl, amphibians, reptiles, and microscopic invertebrates in SRS reservoirs and wetlands; on the effects of site operations on site sediments; on the breeding biology of endangered wood storks; on potential methods to contain or mitigate the effects of hazardous wastes in soils; and on the effects on organisms of exposure to varying levels of several organic and heavy metal contaminants and radionuclides. Other studies examine the ecology of SRS streams and the natural successional processes in site wetlands recovering from site industrial activities. SREL's Division of Environmental Outreach and Education participates in presentations to off-site groups, communicates information to the public concerning research activities at the laboratory, and coordinates the facility's education program.

\section{USFS Research}

USFS research is designed to support the SRS mission, with emphasis on technology transfer and application to other land management organizations. SRFS contributes four to five person-years in support service, ranging from establishing silvicultural treatments to administration of the program reviews and budgets. More than 100 individuals from 20 institutions work in five major program areas involving 80 studies.

Red Cockaded Woodpecker Recovery Program studies range from basic monitoring to translocation strategies and techniques, foraging behavior and food sources, and competition with other wildlife. The Biodiversity Program is the largest SRFS research program, with 37 studies. Its primary goal is to support land-use decisions and land management planning. Research also is focused on restoration ecology technology, species conservation strategies, monitoring techniques, and landscape patterns and processes. The Wetland Restoration Program is concentrated on restoring and monitoring the recovery of 300-400 acres of the Pen Branch riparian-wetland forest and related wetlands destroyed by hot water from reactors. The Fuelwood Biomass Program is designed to aid the nation's effort to commercialize wood biomass as an alternative source of transportation fuels and energy. The primary concerns deal with the impacts of large-scale plantations on the environment; seedling quality, and the recycling of organic wastes to ameliorate sites and improve productivity. The Forest Operations Program is aimed at improving operations and cost efficiency. Current research includes disease and insect control, smoke management, herbicide fate/pine straw raking, longleaf pine regeneration technology, and economic returns from longleaf pine on long rotation. 


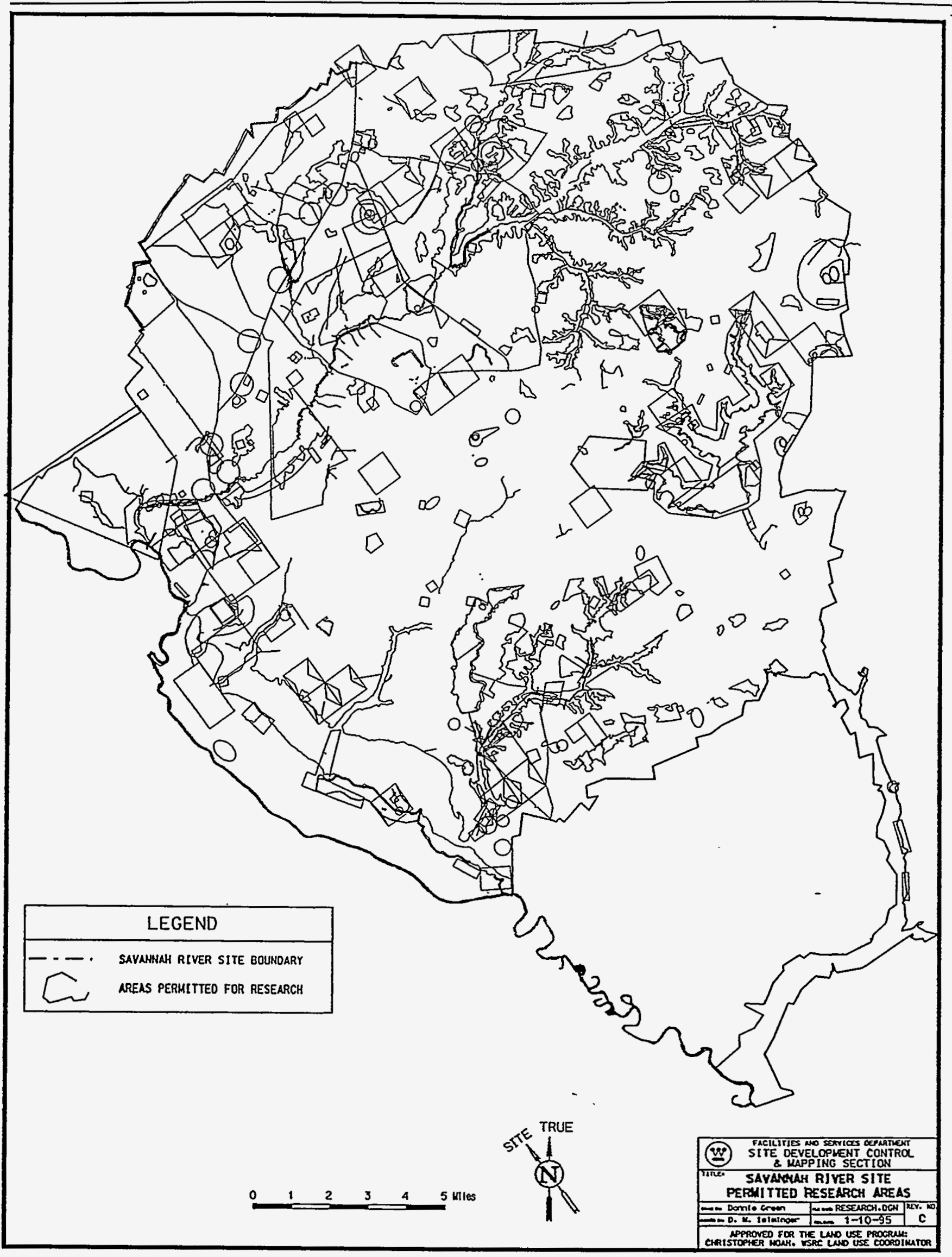

Figure 6-11 


\section{Forest Cover Types}

\section{Overview/Program Description}

SRFS is responsible for managing SRS forests. Direction is given in general terms in the site Natural Resource Management Plan and in more detail in the operations plan. All timber management activities are coordinated with other resource management activities.

\section{Purpose/Missions}

Figure 6-12 shows existing forest "cover types," which are defined as species or groups of species that fit into one of four categories:

- Longleaf Pine - pure longleaf pine and longleaf pine, with a mix of various hardwoods
- Other Pine - pure loblolly pine, pure slash pine, and either species with a mix of various hardwoods

- Upland Hardwood - hickories, trees in the white oak and red oak groups, and other associated species that grow on dryer upland soils. There may be a mix of various pine species within this category.

- Bottomland Hardwood - trees that generally grow on bottomland sites, including wetlands. There are many species in this general classification. Some of the dominant species are swamp chestnut oak, cherrybark oak, sweetgum, tupelo gum, bald cypress, sugarberry, American elm, green ash, laurel oak, willow oak, water oak, nuttall oak, willow, river birch, red maple, sycamore, sweet bay, magnolia, and cottonwood. 


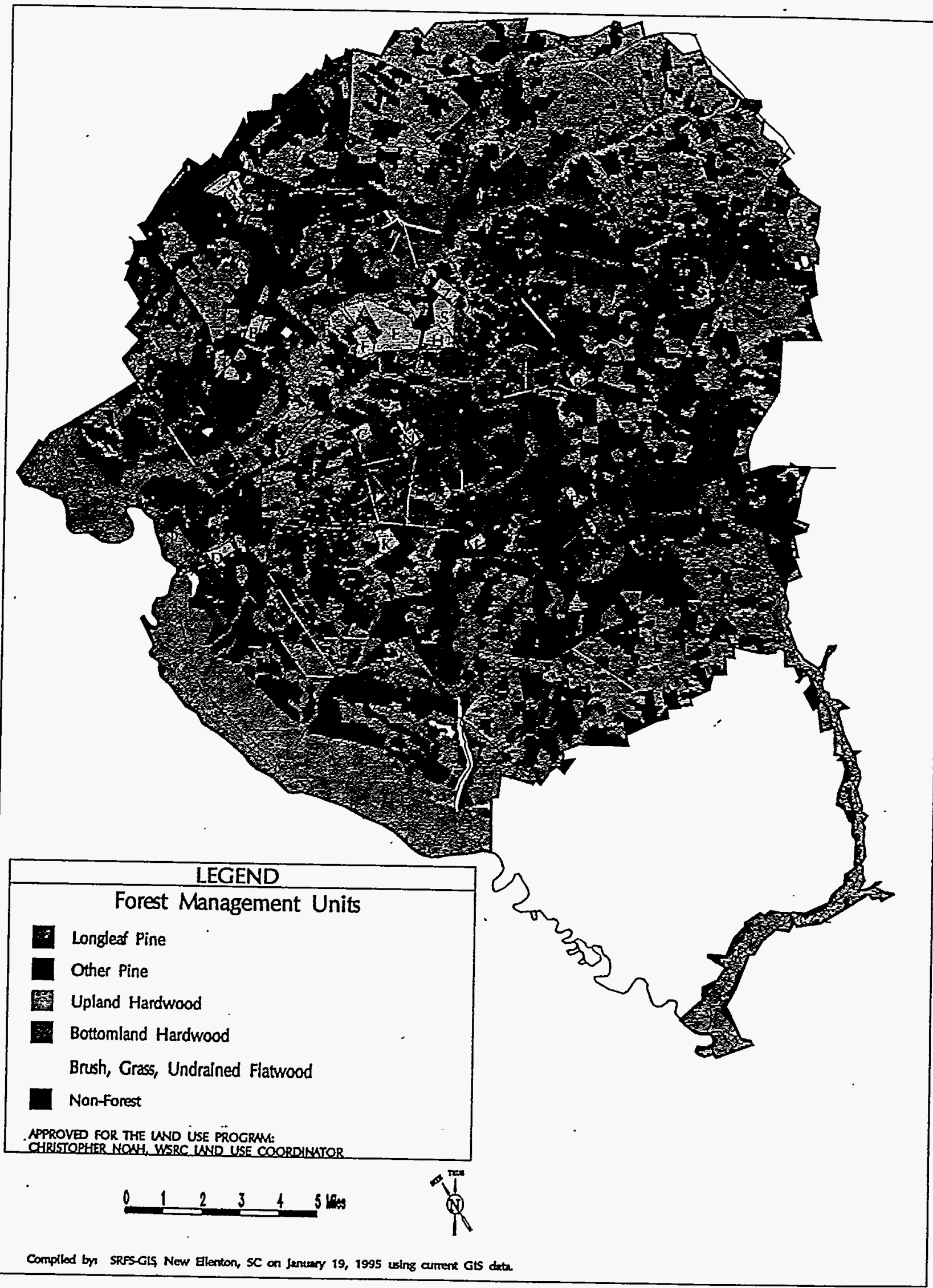

Figure 6-12 


\section{Wildlife - Inventory and Management}

\section{Overview/Program Description}

The overall wildlife, fisheries, and botany objectives of SRS are to

- attain and maintain viable populations of all plant and animal species native to this region

- effectively manage the wildlife, fisheries, and botanical resources to maintain biological diversity and productivity

- control animal populations to reduce safety hazards and property damage

Wildlife management at the site-the responsibility of SRFS-is directed by the SRS Natural Resource Management Plan. A major emphasis is the development of active partnerships with various agencies and organizations working with SRFS to implement the program.

\section{Purpose/Missions}

The wildlife, fisheries, and botany program is divided into the following elements:

- program planning and resource coordination

- proposed, threatened, endangered, and sensitive species habitat improvement

- wildlife, fisheries, and botany habitat improvement
- deer and game management

- animal damage control

- monitoring

Resource coordination includes interdisciplinary teams surveying areas for potential impacts on plants and animals and their associated habitats. This information, along with any recommended mitigation, is documented in a biological assessment or evaluation. Other work includes the monitoring of plant and animal populations, many of which are "indicator species of ecosystem health."

On-site habitat enhancement and maintenance are based on two primary management areas, as shown in figure 6-13. The outer perimeter of SRS (Management Area 2) is managed for a longleaf, fire-dependent ecosystem on the drier sites. The endangered red-cockaded woodpecker is encouraged in this area. Prescribed fire is an important tool used to control hardwood midstory in this habitat. The area features longleaf pine and typically older trees. Management Area 1 is managed for a variety of sustainable uses, including wildlife habitat, as well as for the production of wood fiber. Riparian habitats also are very important, and many diverse plant species are associated with these areas. Considerable work is conducted to restore unique communities, such as Carolina bays. 


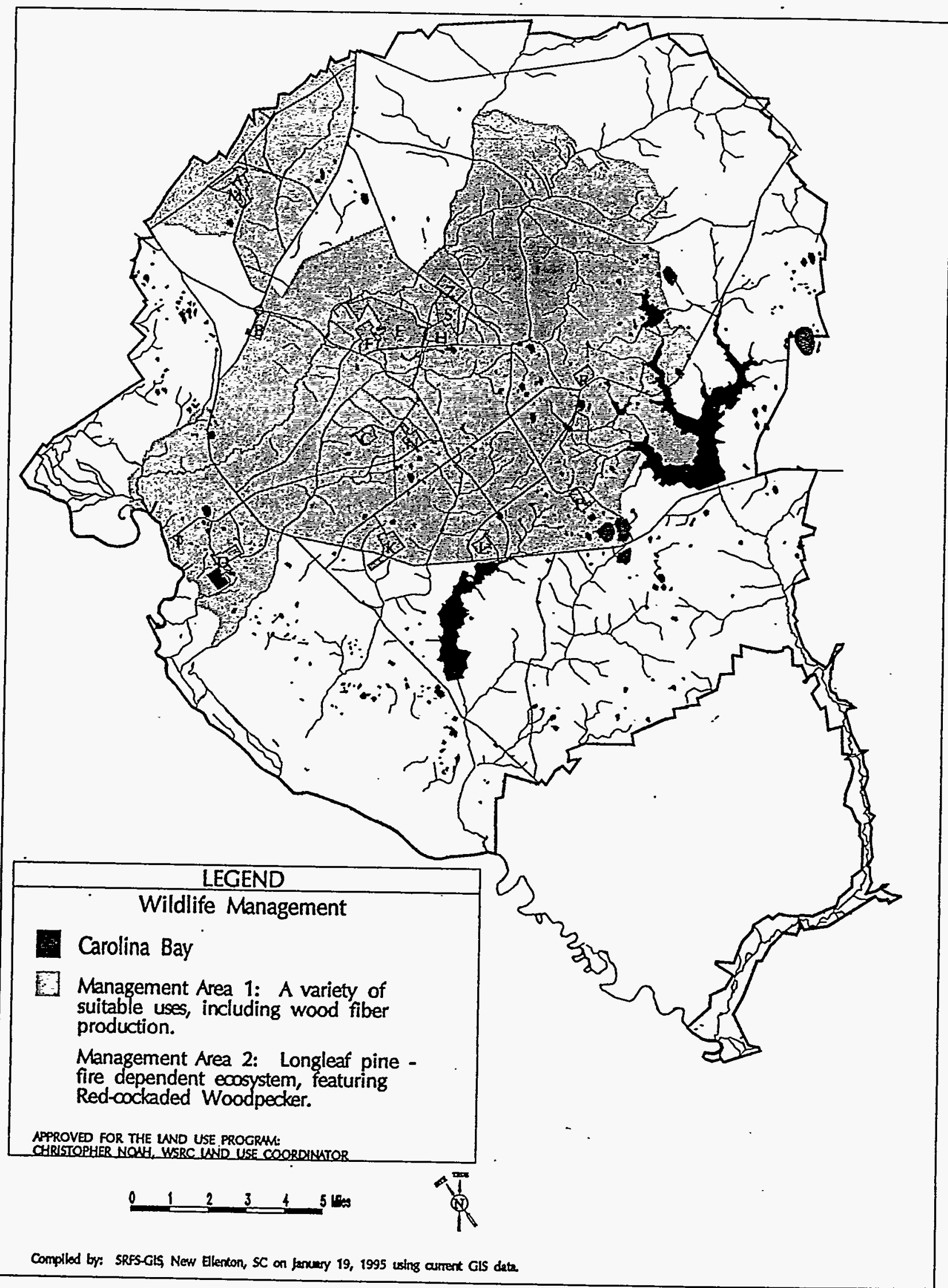

Figure 6-13 


\section{Threatened/Endangered/Sensitive-Species Management}

\section{Overview/Program Description}

An endangered species is one that is in danger of extinction throughout all or a significant portion of its range. A threatened species is one that is likely to become endangered throughout all or a significant portion of its range within the foreseeable future. Sensitive species are simply those for which population viability, or continued existence, is a "concern."

The overall objective of the USFS wildlife, fisheries, and botany program at SRS is to attain and maintain viable populations of all plant and animal species native to the region to ensure the maintenance of biological diversity. The Endangered Species Act (ESA) requires a proactive approach to endangeredand threatened-species management on federally owned land. However, no minimum acreage is required by law. SRS works closely with the U.S. Fish and Wildlife Service(USF\&WS) to determine the adequate habitat necessary to maintain threatened and endangered species. Endangered and threatened species are designated and administered by the USF\&WS. The management of rare species, a vital part of the overall wildlife, fisheries, and botany program at SRS, is the responsibility of SRFS.

\section{Purpose/Missions}

SRS provides habitat for five endangered species, Several reside on the site year-round, while others are transient visitors (figure 6-14). The number of red-cockaded woodpeckers has grown from four birds in 1985 to 77 birds in 1994, and the site supports two active breeding pairs of bald eagles. Also, the endangered wood stork forages on site, and the shortnose sturgeon, an anadromous fish, has been reported in the Savannah River adjacent to SRS. The American alligator, fairly abundant on the site, is listed as threatened (by virtue of similarity in appearance to the endangered crocodile). The smooth purple coneflower is an endangered plant found at two locations on the site.

SRS also is home to many sensitive species, including 28 plants, five birds, three reptiles, one fish, two mussels, three mammals, an amphibian, and an insect. These are species, without ESA protection, for which the population viability is of concern to the USFS. The purpose of identifying sensitive species is to ensure species viability and to prevent any trend toward endangerment that would result in the need for federal listing under the ESA.

In addition to providing habitat for the federally endangered species, SRS hosts several threatened plant, bird, and animal species listed by the State of South Carolina as "Species of State Concern." 


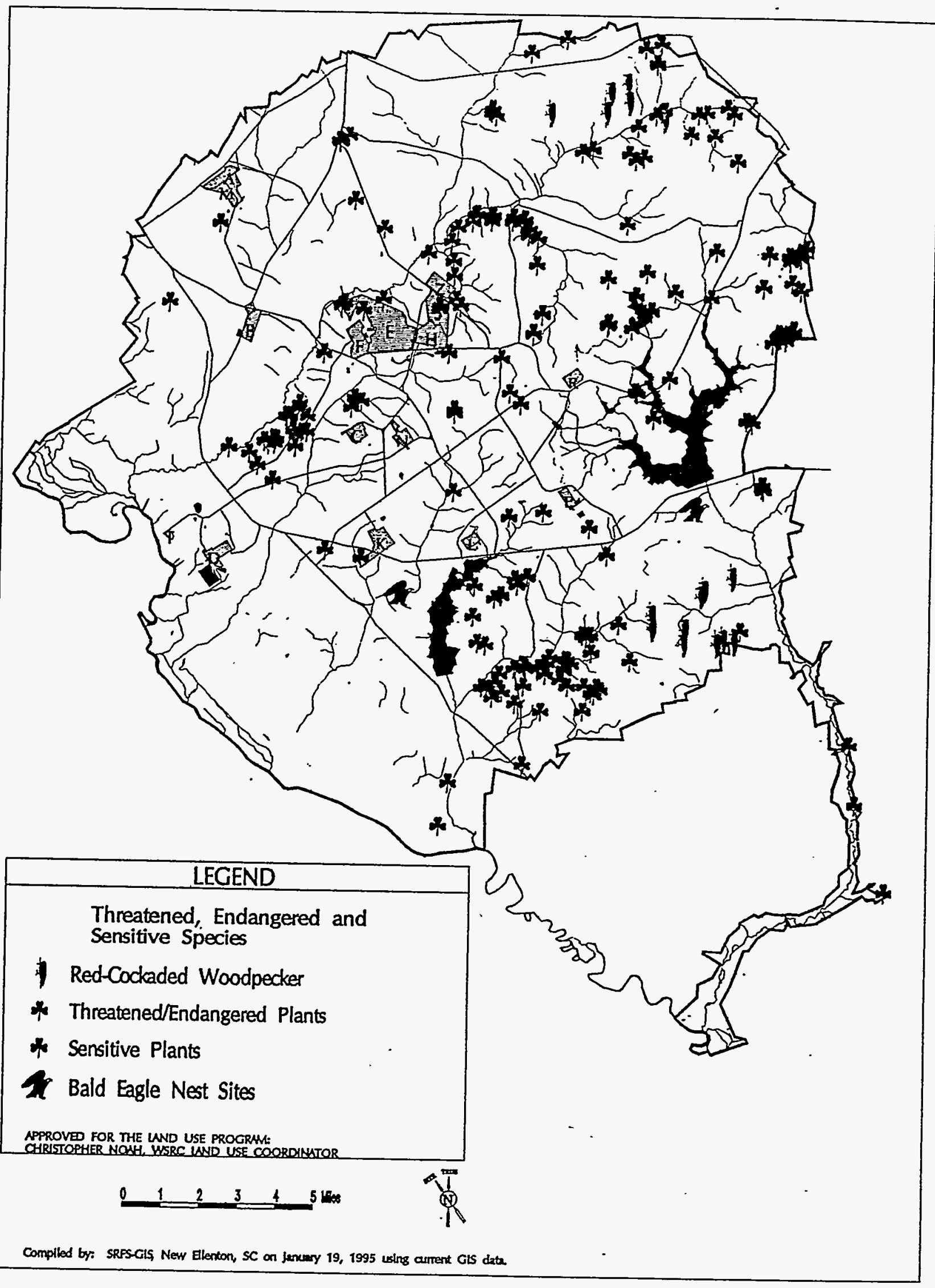

Figure 6-14 


\section{Fire Management}

\section{Overview/Program Description}

The SRFS wildland fire management program is designed to provide and execute a well-planned, cost-efficient fire protection and use program that is responsive to the SRS Natural Resource Management Plan.

\section{Purpose/Missions}

The fire management program's goals and objectives include 1) protection of SRS facilities and personnel from the hazards of wildfires and 2) support of other natural resource management programs with prescribed buming activities to reduce fuels, prepare planting sites, and manipulate vegetation for wildlife habitats. The program consists of three componentspresuppression, fire suppression, and fuels management.

Presuppression includes planning, budgeting, and implementing activities that lead to a highly effective state of readiness. This entails the identification and development of agreements and memoranda of understanding with on-site and off-site organizations for a mutually improved fire protection capability.
To ensure that fire suppression objectives are met as cost-effectively as possible, SRFS uses the National Fire Management Analysis System, which defines proper staffing and equipment levels that must be maintained. During the past 12 years, the largest number of fires occurring during a single year was 27. These fires, in 1985, burned 320 acres. Lightningcaused fires represent 31 percent of all fires on site, while person-caused fires represent the remaining 69 percent. Arson-caused fires have remained low, at an average of two per year.

The fuels management program involves the treatment of forest fuels to reduce the damaging effects of wildfires. Fuels management activities may be initiated when natural processes or management activities create a highly flammable fuel bed. Prescribed fire is planned for use on approximately 15,000 to 20,000 acres annually. Figure $6-15$ shows areas that were prescribe-burned from fiscal years 1987-1990. The application of prescribed fire is used not only to benefit the fire management program, but also to manipulate vegetation for the benefit of natural resource functions, such as wildlife habitat improvement. 


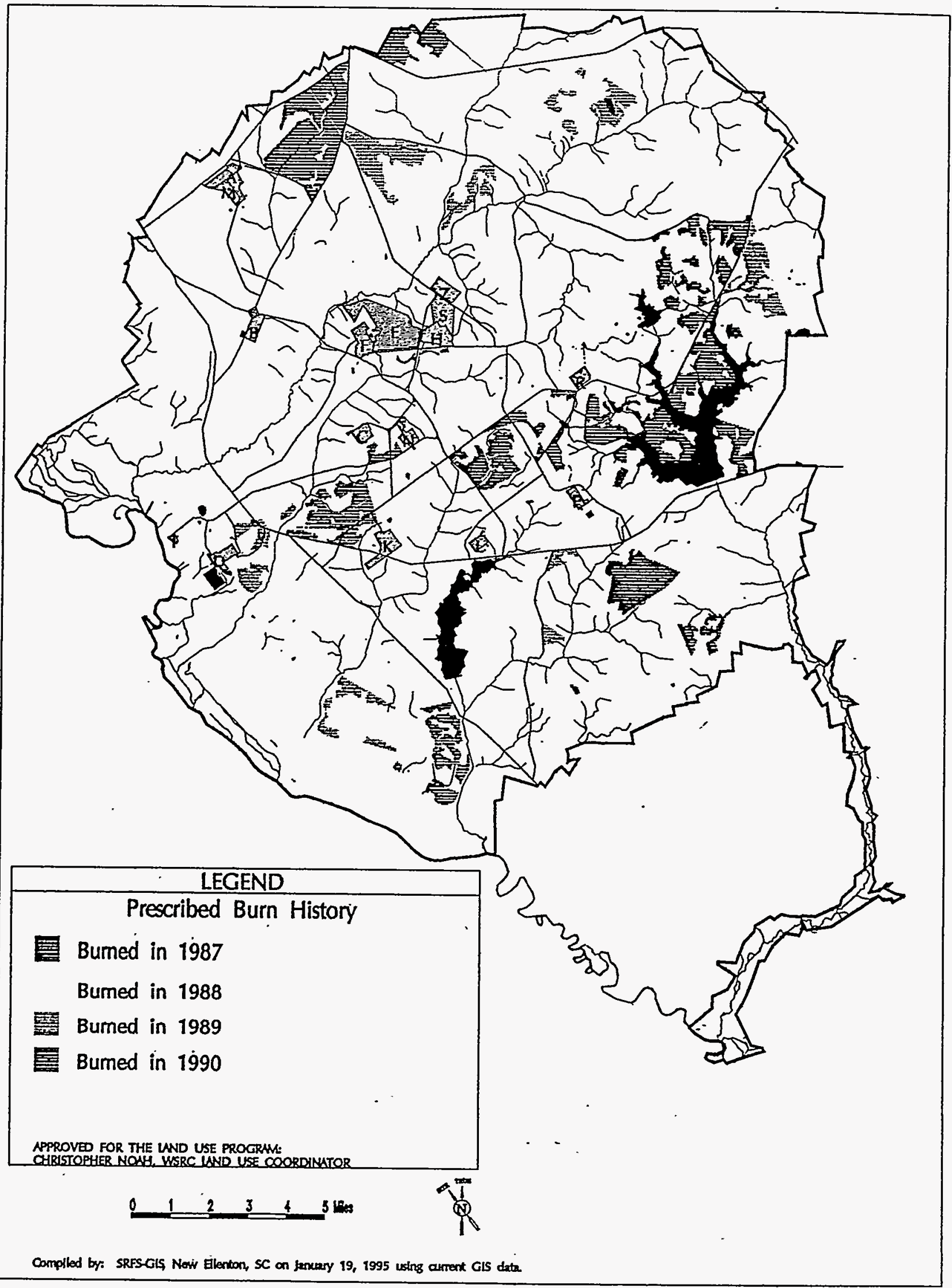

Figure 6-15 


\section{Archaeological Sensitivity Zones/Cemeteries}

\section{Overview/Program Description}

SRS archaeological activities are mandated by Executive Order 11593, the National Historic Preservation Act, and the National Environmental Policy Act of 1969 (NEPA). In accordance with these laws and regulations, the Savannah River Archaeological Research Program (SRARP) of the South Carolina Institute of Archaeology and Anthropology, University of South Carolina (SCIAA), began in 1973 with a phased approach to archaeological compliance involving reconnaissance surveys, general intensive watershed surveys, project-specific intensive surveys, and data recovery (excavation) projects. The data derived from these archaeological activities, in conjunction with close coordination with major land users, facilitate the management of archaeological resources at SRS. For land-use planning purposes, archaeological sites are governed by Section 106 of the National Historic Preservation Act of 1966, as amended in 1981. This means that, prior to use, all land is intensively surveyed for archaeological sites, with the sites evaluated for significance according to National Register of Historic Places criteria.

\section{SRS-Recorded Archaeological Sites}

The SCIAA has conducted an archaeological survey at SRS since 1974. In examining approximately 65 percent of SRS's 803 square kilometers, this survey has recorded more than 1000 archaeological sites to date. The largest scale archaeological investigation in the region, it provides a comparative base from which to project the region's general archaeological characteristics.

\section{Purpose/Missions}

The primary purpose of the SRARP is to provide DOE-SR with recommendations concerning the management of cultural resources. The Site Use Review System, administered by DOE-SR's Assistant Manager for Engineering and Projects, assures consideration of cultural resources in all land-use planning. The proper management of those resources depends on ongoing research to assess archaeological site significance. Through the integration of cultural resource management and research, the SRARP acquires new knowledge about the past for dissemina- tion to the public and the professional archacological community. Collectively, the SRARP missions (cultural resource management, research, and public education) form the foundation of the working relationship between DOE and the SRARP/SCIAA and are consistent with both the letter and spirit of the law.

\section{Sensitivity Zones}

The Archaeological Sensitivity Zones depicted in figure $6-16$ were formulated by the SRARP (Archaeological Resource Management Plan, 1989) to assist land-use planners at SRS. The zones were defined on the basis of statistical variation in locational and artifact assemblage composition data from known SRS archaeological sites (locations of past human activity, as determined by the occurrence of artifacts) at SRS and are used to predict the locations of similar sites. Archaeological Sensitivity Zone I has the highest probability of containing significant archaeological resources, and land-altering activities should not be conducted within it In contrast, Archaeological Sensitivity Zone III is least likely to contain significant archaeological resources or to impede proposed land-altering activities. Indeterminate Sensitivity Areas consist of the swamps of the Savannah River floodplain and tributary floodplains in which no archaeological survey has been conducted.

Figure 6-16 depicts only "archaeologically sensitive zones" because of the requirement of confidentiality with respect to the location of all archaeological sites, as expressed explicitly in Section 9 of the Archaeological Resource Protection Act of 1979 and in Section VI(B) of the Programmatic Memorandum of Agreement (1990) among DOE-SR, the South Carolina State Historic Preservation Officer, and the Advisory Council on Historic Preservation.

\section{Cemeteries}

Most cemeteries of the historic/modern era that were present at SRS were relocated off site in the early 1950s. The remnant cemeteries (those not relocated) on the site are also shown in figure 6-16. These cemeteries; some of which remain active, are protected by state and federal laws and through the Site Use System, and DOE guarantees public visitation and access rights to them. 


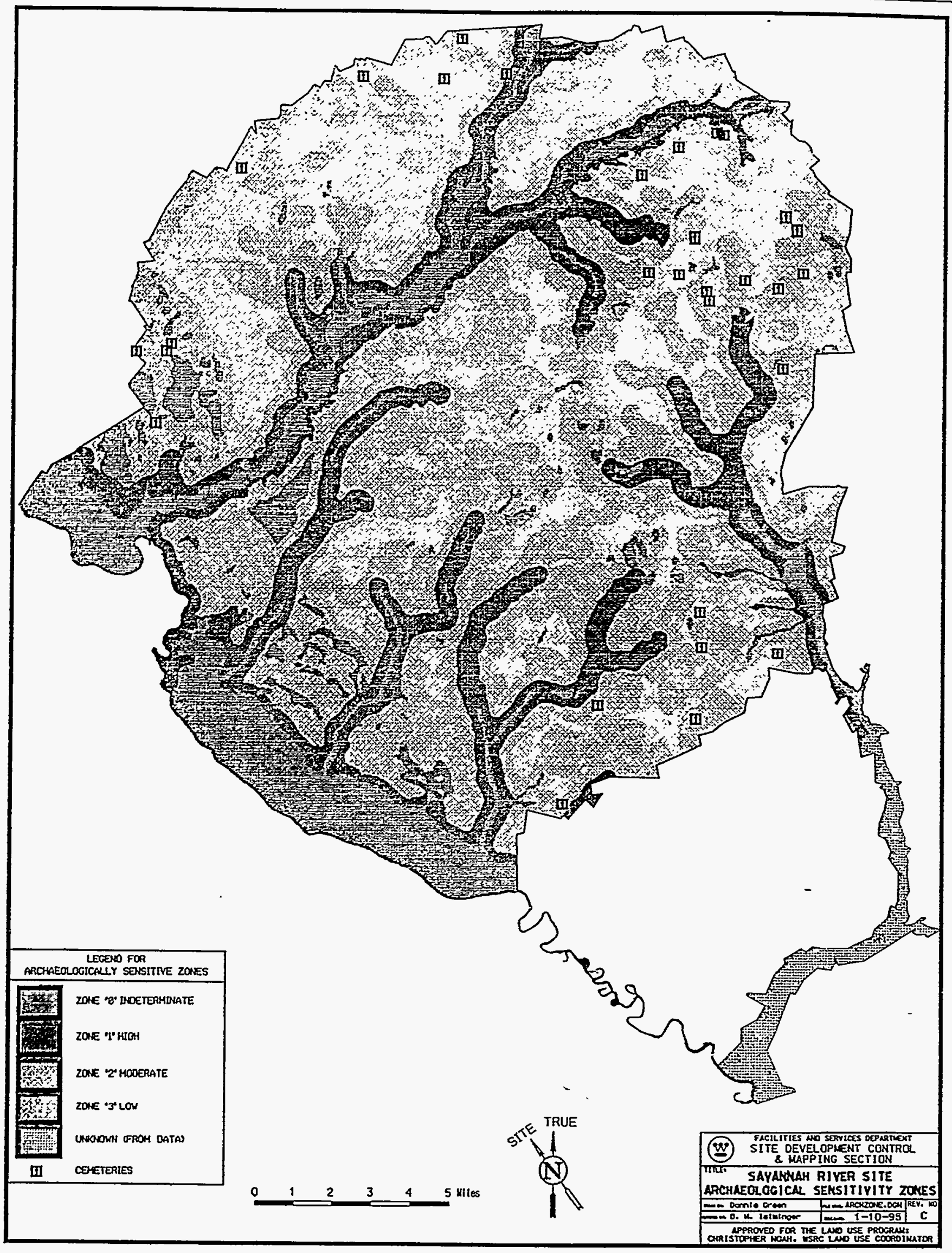

Figure 6-16 


\section{Recreation}

\section{Overview/Program Description}

\section{Trails}

SRFS has constructed and maintains three walking trails (figure 6-17) at SRS to provide opportunities for employees to exercise during lunch breaks and nonworking hours. The Piney Woods Trail is on the north side of SRS Road 1, across from the 700-Area. The "S" Area Trail is on the north side of SRS Road F across from $S$-Area complex. The third trail is located at the SRFS administrative site.

\section{Boy Scout Camporee}

SRFS supports SRS each year in hosting the annual Georgia-Carolina Boy Scout Council Fall Camporee, where about 500 Scouts work toward merit badges during a weekend of camping and other activities on the site.

\section{Hunting/Fishing}

A portion of SRS is open to the public for hunting and fishing. Public hunts are allowed under DOE Order 4300.1C, which states that "all installations having suitable land and water areas will have programs for the harvesting of fish and wildlife by the public." The Crackerneck Wildlife Management Area is comprised of 4,780 acres of the site located adjacent to the Savannah River. This area is cooperatively managed by SRFS and the South Carolina Department of Natural
Resources. Sportsmen must obtain a permit to hunt or fish this area; however, there is no charge. Opportunities exist to hunt waterfowl and big (deer, hogs, and turkeys) and small (quail, squirrels, and rabbits) game, and to catch a variety of fish.

\section{Controlled Hunts}

Hunting opportunities also are available on much of the rest of the site. SRFS is responsible for developing and coordinating a comprehensive deer control programin close cooperation with WSRC, SREL, the South Carolina Department of Natural Resources, and Wackenhut Security, Inc. Recreation is not the primary purpose of these controlled hunts. The mission of this activity is to conduct harvests that will

- lower the incidence of animal-vehicle collisions on site

- produce a healthy deer population

- reduce the feral hog damage to valuable plant communities, reforestation efforts, and ecological research sites

Figure 6-17 also illustrates the administrative hunt units, which are analyzed and scheduled for various hunt strategies. There is a $\$ 50$ fee to hunt, and hunters are chosen at random from a list of those who registered. Each animal harvested is monitored for contaminants, and harvest data such as age, sex, and weight are compiled. . 


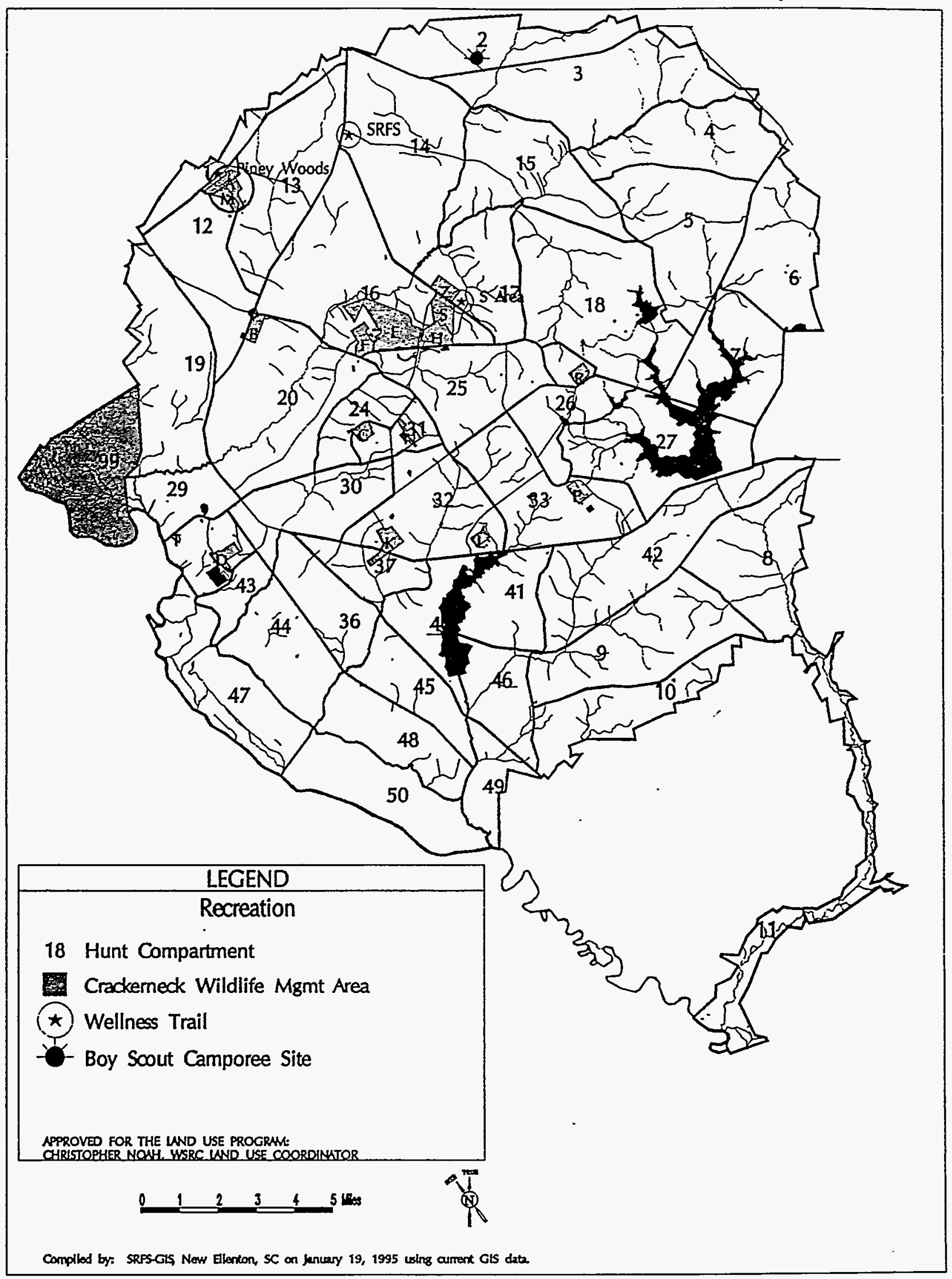

Figure 6-17 


\section{Topography/Cadastral}

\section{Overview/Program Description}

SRS is located along the Savannah River approximately midway between South Carolina's piedmont mountains and the Atlantic Ocean. About one-third of the land is in the southwest comer of Aiken County, and nearly two-thirds is in the westem part of Barnwell County. A small part of the site is in the western part of Allendale County, principally along Lower Three Runs Creek. The Savannah River acts as the western boundary of SRS and is the boundary between Georgia and South Carolina.

The area often is referred to as the "Sand Hills." Topographic relief at SRS ranges from the long, narrow, steep areas on slopes on the east sides of Upper Three Runs Creek and Tinker Creek to the nearly level areas on stream terraces west of SC Highway 125 (figure 6-18). Elevation ranges from about 420 feet near the Aiken Gate House (northern part of the site) to about 70 feet where Lower Three Runs Creek enters the Savannah River (southeastern part of the site). Most of the drainage from SRS is into the Savannah River, a small portion of the site drains to the Salkenhatchie River. Portions of the site are in the U.S. Army Corps of
Engineers 100-year floodplain designation (figure 6-19).

The SRS boundary is established to the north, south, and east by a marked property line (figure 6-20); most of its western boundary is the Savannah River. These boundaries enclose 310 square miles of real estate. The southern tail of the site, commonly referred to as the Lower Three Runs Corridor, follows the confluence of Lower Three Runs Creek, a tributary of the Savannah River, and is bounded on both sides by a marked property line to its junction with the river. All site property lines are inspected regularly and maintained by SRFS and WSRC personnel. The site occupies 114 square miles of Aiken County, 190 square miles of Barnwell County and 6 square miles of Allendale County (figure 6-20).

\section{Purpose/Missions}

Topography is especially important when siting new buildings or large-scale facilities. Because of the extensive area and diverse topographic nature of SRS, site selection for future activities requires careful consideration and study. Understanding the topography facilitates the site selection process. 


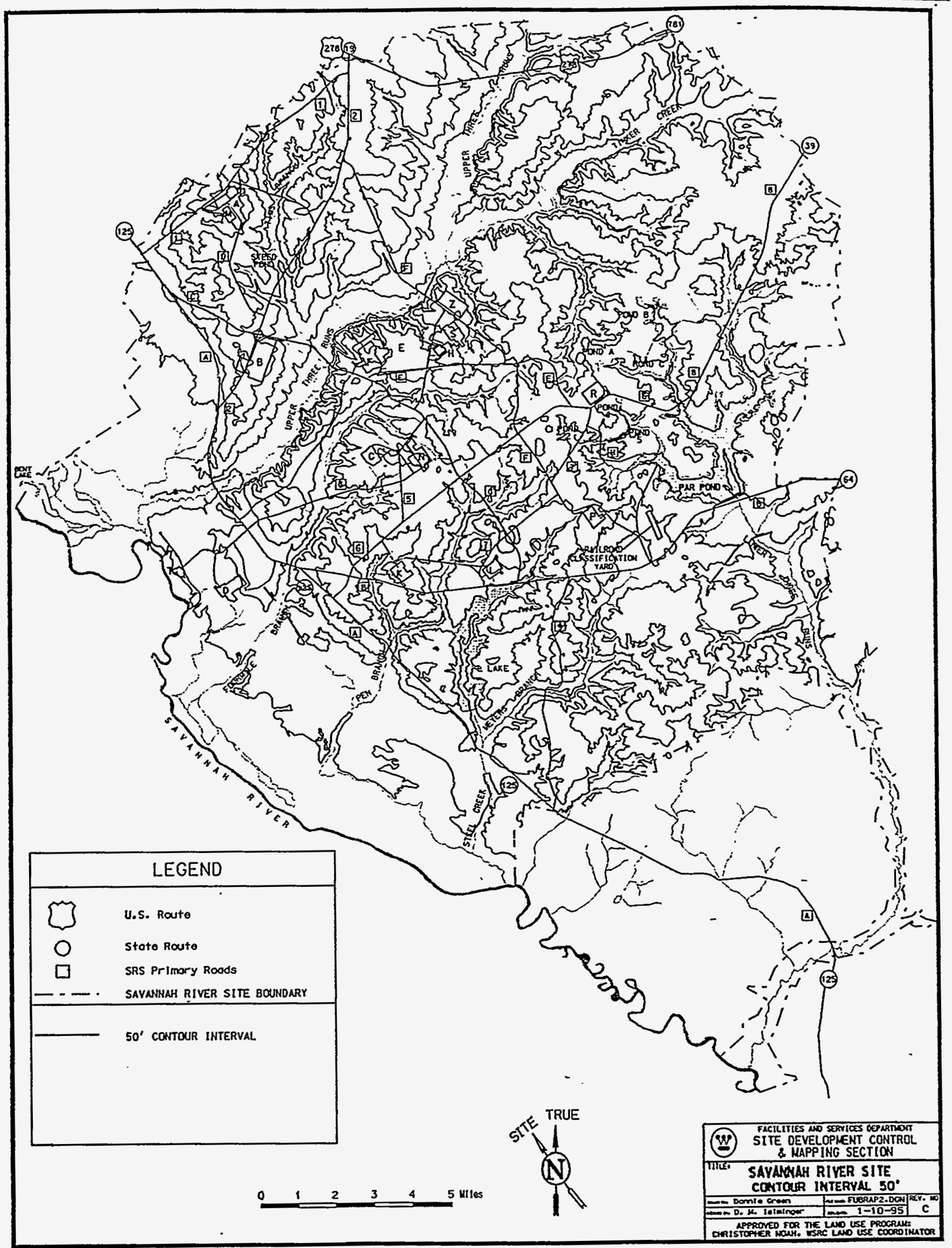

Figure 6-18 


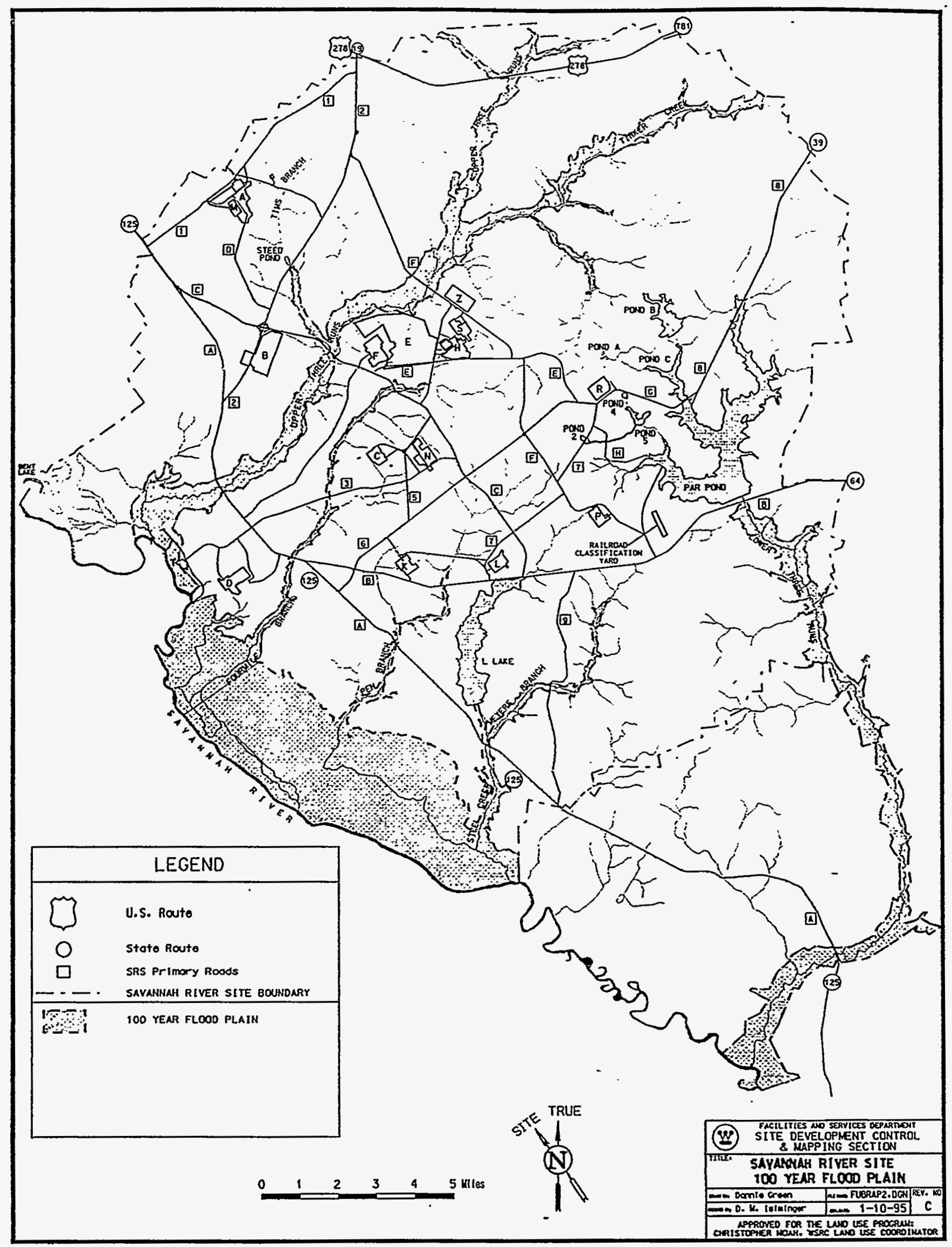

Figure 6-19 


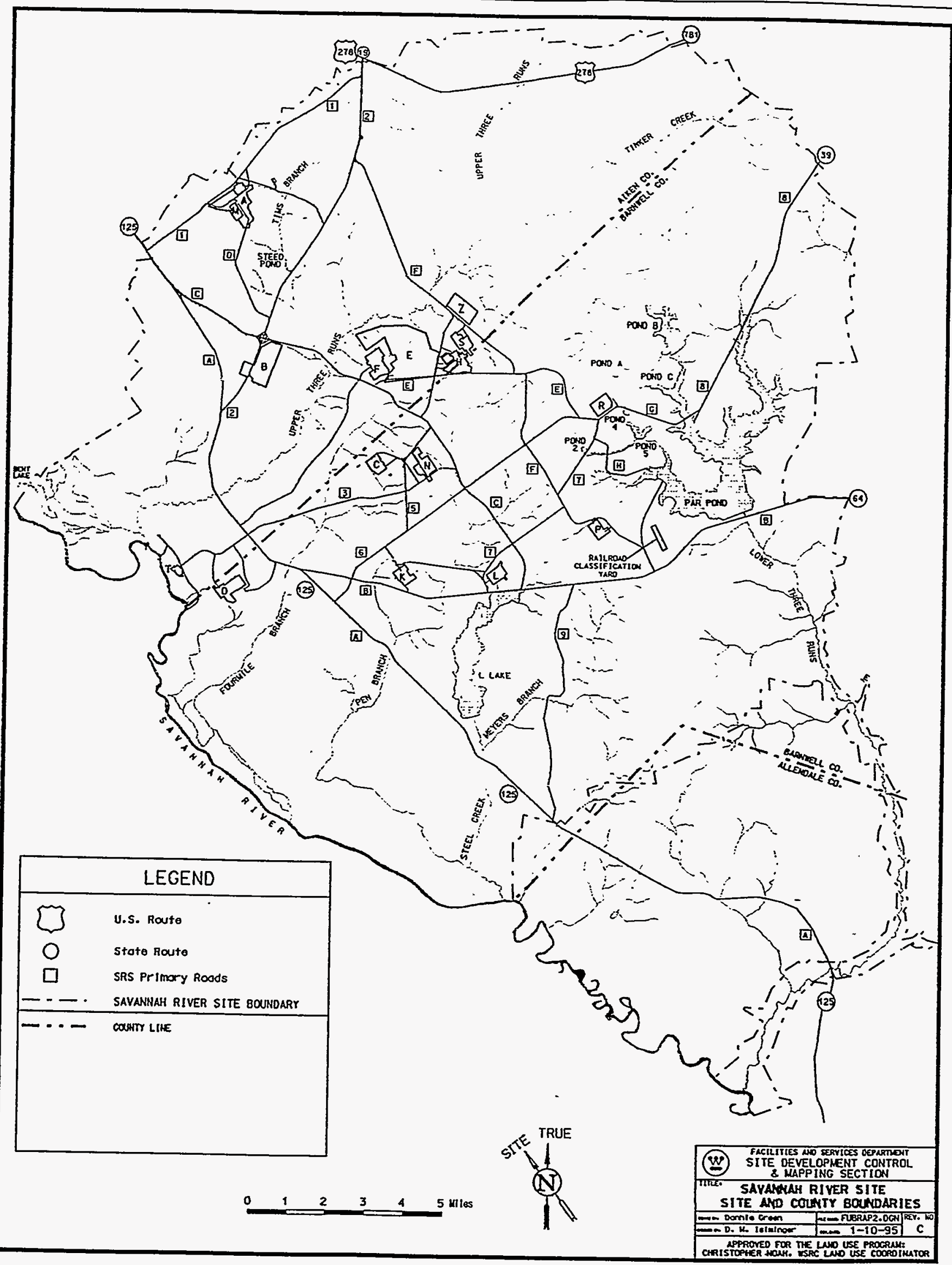

Figure 6-20 


\section{Surface Water}

\section{Overview/Program Description}

SRS is bordered on the southwest by the Savannah River for about 27 miles. The site's main streams are (east to west) Lower Three Runs Creek, Steel Creek, Pen Branch, Fourmile Branch (also known as Four Mile Creek), and Upper Three Runs Creek (figure 6-21). Beaver Dam Creek is a small stream that drains $D$-Area and that may have been a seasonal stream prior to SRS operations. Of the larger streams, the drainages of Steel Creek, Pen Branch, and Fourmile Branch are contained entirely within SRS, and all three flow through the Savannah River Swamp prior to discharging to the river. Steel Creek and Fourmile Branch have defined flow paths to the river, while Pen Branch flows through the swamp and joins the flow of Steel Creek before entering the river. Lower Three Runs Creek, the second largest drainage, originates on SRS and flows directly to the Savannah River, with the lower reaches of its drainage located off site. Upper Three Runs Creek is the largest of the streams, and the majority of its drainage basin is located on site. Other main streams include Tinker Creek and Tims Branch.

Of the approximately 310 square miles comprising SRS, about 20 percent are classified as wetlands, including open water. Bottomland hardwood forest, occurring mostly along stream corridors and in the Savannah River Swamp, and cypress-tupelo forest, found predominantly in the swamp, account for about
78 percent of the site wetlands. SRS surface waters include more than 50 artificial impoundments, six tributaries of the Savannah River, and the Savannah River Swamp. Par Pond (2,640 acres) and L Lake (1,000 acres) are the largest artificial impoundments. Site tributaries flow into the Savannah River via the Savannah River Swamp, a 3,800-acre riverine swamp bordering the river and separated from it by a natural levee. The swamp is contained within the site boundaries.

\section{Purpose/Missions}

All site streams except Upper Three Runs Creek have received thermal effluents from SRS operations. The effects of these discharges are evident but are diminishing over time. Major thermal discharges have been eliminated and are being mitigated. All drainages, however, receive effluents from NPDES-permitted discharges.

SRS also contains two large reservoirs, Par Pond and $L$ Lake, formed by impounding the headwaters of Lower Three Runs Creek and Steel Creek, respectively. In addition to the main reservoir, the Par Pond system contains a series of small precooler ponds and canals that were used to transport water from R-Reactor and P-Reactor to Par Pond. The 'site also has numerous small farm ponds and a large number of Carolina bays, which are natural wetland features unique to the Atlantic Coastal Plain. 


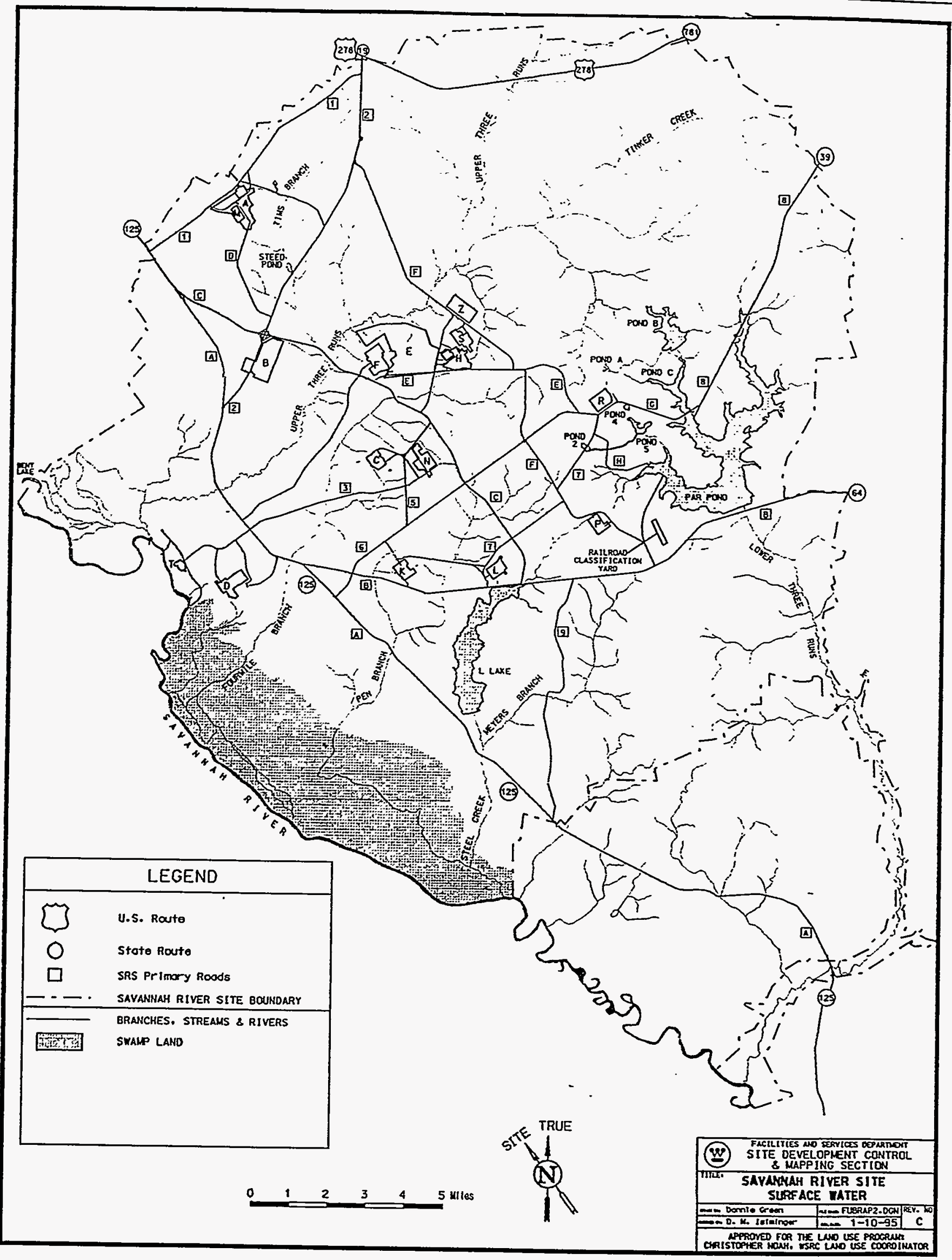

Figure 6-21 


\section{Groundwater}

\section{Overview/Program Description}

Groundwater resources are affected by many physical factors, including aquifer leakage, natural variations over distance, and differences in behavior caused by natural and pumping cycles. Groundwater use and quality at SRS are related to each other, as well as to surface water use and quality (with groundwater providing base flow for streams and for discharges to the Savannah River).

Groundwater quality is a concern to human health and the environment. Monitoring involves the periodic sampling and analysis of groundwater from wells located near operating and closed sites to detect possible contamination.

In the southeastern United States, Atlantic Coastal Plain sediments that overlie the basement complex constitute a multilayered hydrologic system of aquifers and aquitards. Significant groups of sand-rich sediments form aquifers, whereas clay-rich sediments form confining units called aquitards. At SRS, the Atlantic Coastal Plain sediments are divided into two major aquifer systems, Dublin-Midville and Floridan, and two confining systems, Appleton and Meyers Branch. These systems are subdivided further into additional aquifer and confining units.

\section{Groundwater Supply}

Excellent-quality groundwater is abundant from many local aquifer units in the SRS region of South Carolina. As a result, the South Carolina Department of Health and Environmental Control (SCDHEC) has classified all aquifers in the state as Class GB (or EPA Class II), which means that the aquifers can provide resource quality water but are not the sole source of supply. The Dublin-Midville aquifer system is known to sustain single-well yields of 2,690,000 gallons per day. This system is being utilized well below its capacity.

At SRS, most groundwater production is from the Dublin/Midville aquifer system, (about 9-12 million gallons per day), with a few lower capacity wells pumping from the Floridan (uppermost) aquifer system. Every major operating area at SRS has groundwater production wells.

SRS use of groundwater has increased over the years because of 1) the convenience afforded by the availability of prolific sources, 2) the transmissivity of the Dublin/Midville aquifer system, and 3) the high quality of the water. Groundwater withdrawals are used primarily for process water; other uses include domestic water and fire protection.

\section{Groundwater Quality}

Groundwater from the Dublin-Midville aquifer system is soft, slightly acidic, and low in dissolved solids.

Groundwater beneath an estimated 5-10 percent of SRS has been contaminated by industrial solvents, tritium, metals, or other constituents used or generated by operations. Groundwater in the areas indicated in figure 6-22 contains one or more of these constituents at or above primary drinking water standards. In most instances, the contamination is confined to the uppermost aquifer system (Floridan).

\section{Purpose/Missions}

Groundwater monitoring is conducted for a wide variety of purposes, including

- compliance with permits, consent decrees, or settlement agreements

- compliance with sections, of RCRA

- investigation of potential impacts due to spills or releases, primarily in compliance with CERCLA

- compliance with DOE orders and best management practices

At SRS, groundwater monitoring for radioactive constituents began in the 1950s; monitoring for nonradioactive constituents began in 1975 . The site's monitoring program now covers more than 100 locations, including waste disposal sites, chemical storage areas, tanks, sewers, spills, buildings, and proposed construction areas (figure 6-22).

Monitoring wells can be exceptional tools for determining the degree and extent of contamination, from which decisions for remediation are based. If improperly constructed, however, the wells can increase the downward migration of contaminants. For this reason, it is important that well construction be uniform and controlled. Guidance and regulations have been utilized to prepare basic construction requirements for monitoring wells installed at SRS. 


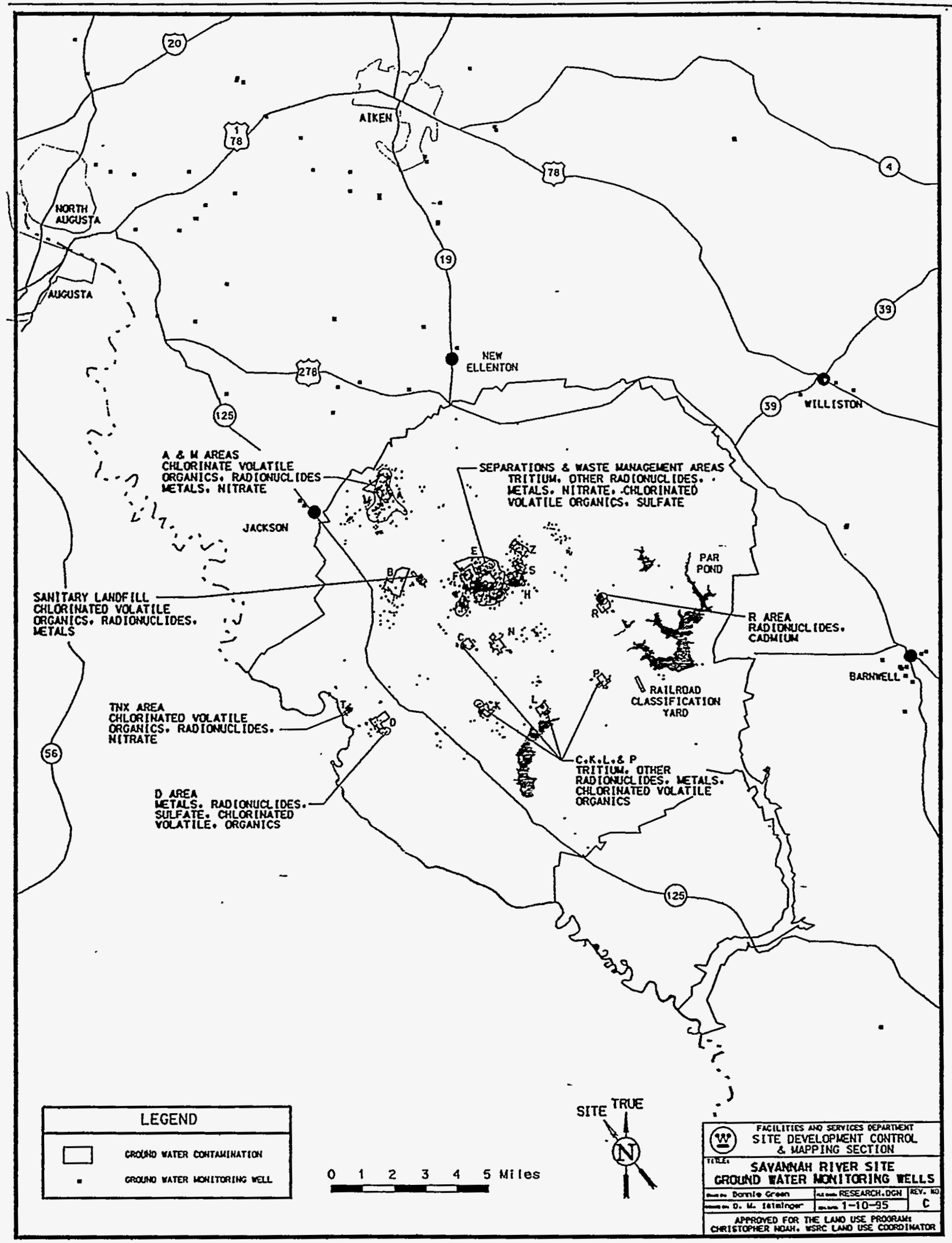

Figure 6-22 


\section{Soils}

\section{Overview/Program Description}

SRS soils generally are on gently to moderately steep slopes. Some soils in the upland area and along the major streams are level. Most soils in these locations are well-drained to excessively drained. Soils on bottom land range from well-drained to very poorly drained. Twenty-nine soil series are identified at SRS and grouped together in seven soil associations. Each association consists of one or more major and minor soils.

Soils are classified based on the organization and thickness of specific identifiable layers related to present-day land surface, and they change with depth. Sediment beneath the soil profile often is the parent material of the soil. Five interrelated soil-forming factors determine the thickness and characteristics of the layers within a given soil profile: parent material, climate, biological activity, topography, and time. Climate is a significant soil-forming factor; however, the relative importance of each soil-forming factor differs from place to place. All characteristics of the resulting soil layers in tum determine the soil's classification.

Figure 6-23 shows soil limitations that affect shallow excavations, small structures, small commercial buildings, and local roads and streets. The map depicts two broad groupings: those soils with and without severe limitations. Data were taken from the Soil Survey of Savannah River Plant Area, Parts of Aiken, Barnwell, and Allendale Counties, South Carolina" (USDA, 1990). Limitations are considered slight if soil properties and site features are generally favorable for the indicated use and if limitations are minor and easily overcome, moderate if soil properties or site features not favorable for the indicated use and special planning, design, or maintenance are needed to overcome or minimize the limitation; and severe if soil properties or site features are so difficult to overcome that special design, significant increases in construction costs, and increased maintenance are required. Special feasibility studies are required where the soil limitations are severe. When planning projects or siting facilities, the soil survey should be consulted for general planning information. A more detailed site analysis will be needed before construction is begun.

\section{Purpose/Missions}

Soil surveys for the area help meet several objectives. Among these are information about specific soil characteristics, such as bulk chemical properties, that may affect migration of chemicals through the soil. Evaluation of soil series at or near sites identified in the RCRA program factors into the characterization and remediation plans of those sites. 


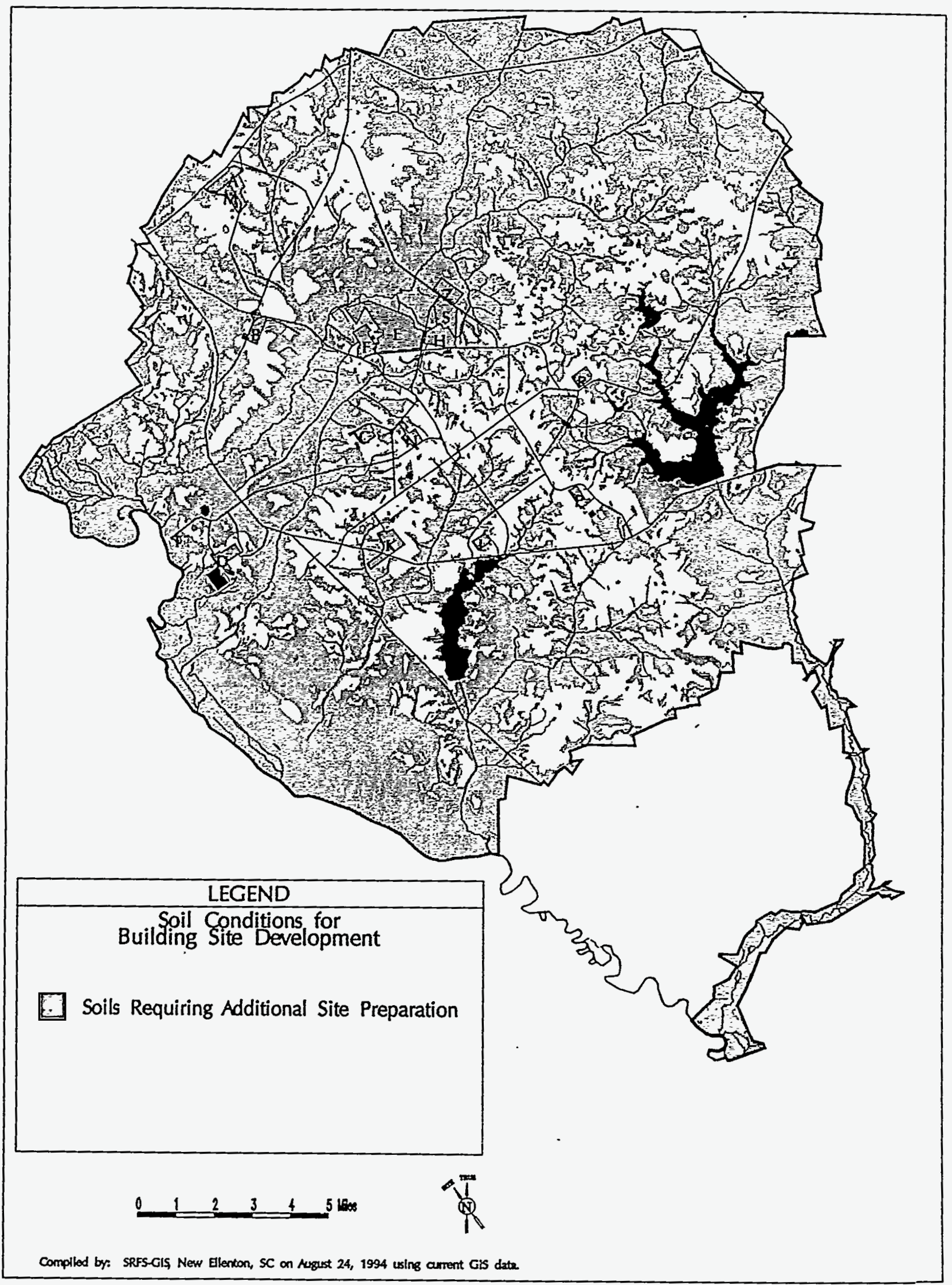

Figure 6-23 


\section{Faults}

\section{Overview/Program Description}

The majority of the subsurface studies at SRS during the past 40 years have been concentrated on the Atlantic Coastal Plain sediments. Data on the underlying basement are much more limited and depend on the interpretation of a few deep borings and geophysical surveys. Standard seismic and high-resolution, shallow seismic reflection and refraction data, in conjunction with potential field data and data from deep cores, have been used to develop a model of structure within the basement complex.

Interpretation of these data characteristically indicates a southeast-dipping basement surface with some minor highs and lows that suggest an erosional surface. This surface is interrupted by several basement faults, the oldest fault of which is perhaps late Paleozoic because it is truncated at the basement/coastal plain interface. The youngest fault may be Tertiary age because deformed sediments of that age in the coastal plain are observed directly overlying the fault. These faults form groups or sets of faults based on age and regional correlation to other known faults.
Faults that have been corroborated or newly identified are

- Pen Branch fault - initially identified as the northern boundary fault of the Triassic basin

- Steel Creek fault-a fault southeast of Pen Branch fault within the Triassic basin and forming a horst with Pen Branch fault

- Atta fault - the north-northeast-trending fault in the north central portion of SRS

- Ellenton fault - a north-south-trending fault, east of D-Area that may intersect Pen Branch fault

- Crackerneck fault - a northeast-trending fault in the northwest portion of SRS

- Upper Three Runs fault - a northeast-trending fault that underlies the current Upper Three Runs drainage.

\section{Purpose/Missions}

There is no evidence to indicate that identified faults at SRS are capable-as defined by the NRC 10 CFR 100 (Appendix A) criteria-of generating significant earthquakes. Figure 6-24 depicts these noncapable faults. 


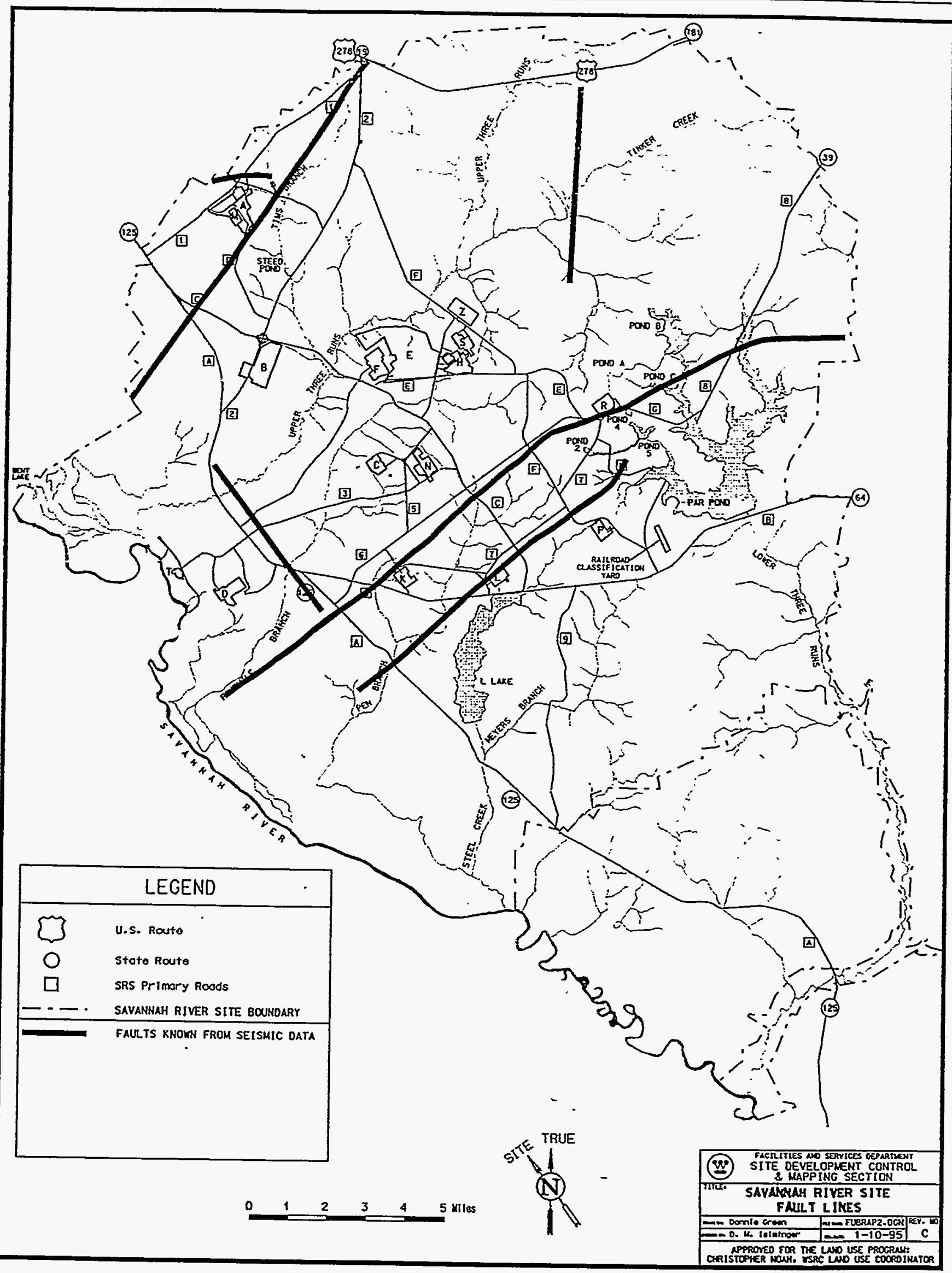

Figure 6-24 


\section{Geology}

\section{Overview/Program Description}

SRS is located on the Atlantic Coastal Plain, which includes unconsolidated marine and river sediments. The sediments are stratified sand, clay, limestone, and gravel that dip gently seaward and range in age from Late Cretaceous to Recent. The sedimentary sequence thickens from zero at the Fall Line to more than 1 mile at the coast. The coastal plain section is divided into several groups, based principally on age and physical characteristics.

Beneath the coastal plain sedimentary sequence at SRS, below a pre-Cretaceous unconformity, are two geologic terranes: 1) a Triassic-Jurassic rift basin, the Dunbarton basin, filled with lithified terrigenous and lacustrine sediments with minor amounts of mafic volcanic and intrusive rock and 2) a crystalline terrane of metamorphosed sedimentary and igneous rock that may range in age from Precambrian to late Paleozoic. The Paleozoic rocks and the Triassic sediments were leveled by erosion, forming the base for coastal plain sediment deposition. The erosional surface dips approximately $8 \mathrm{~m} / \mathrm{km}$ toward the southeast.

\section{Purpose/Missions}

The coastal plain sediments, the underlying crystalline basement, and the regional geology impact the facilities at SRS in many areas of concem, from groundwater movement to seismic hazard (figure 6-25). 


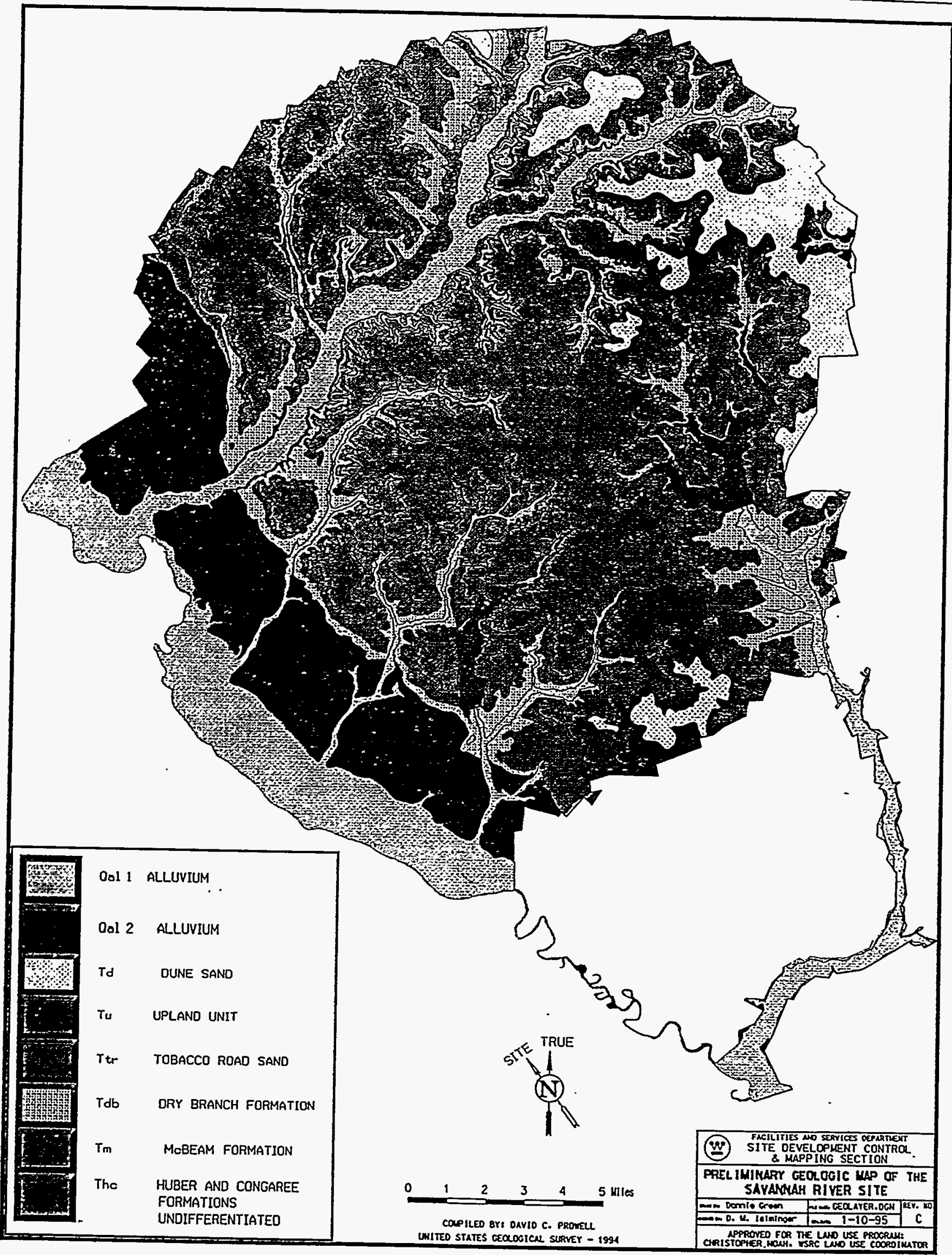

Figure 6-25 


\section{RCRA/CERCLA Waste Units and Site Evaluations}

\section{Overview/Program Description}

SRS manages waste materials regulated under RCRA, a comprehensive law requiring stringent management of hazardous waste/constituents. The Hazardous and Solid Waste Amendments were passed in 1984 to further augment RCRA.

Regulated units are surface impoundments, landfills, and waste piles (collectively termed "land disposal units") that have received hazardous waste since November 19, 1980, and that require RCRA operating or post-closure permits. Nonregulated units, termed Solid Waste Management Units, may include any activity where hazardous constituents may remain uncontrolled and potentially released to the environment. Investigations and corrective actions at these units are mandated by RCRA Section 3004(u).

On December 21, 1989, SRS was placed on the National Priority List. A site included on the list falls under the jurisdiction of CERCLA, as amended by the Superfund Amendments and Reauthorization Act of 1986. These acts impose requirements for the remediation of hazardous substance releases and of inactive hazardous waste disposal sites. The National Oil and Hazardous Substances Pollution Contingency Plan (40 CFR 300) was established under Section 105 of CERCLA. Its purpose is to provide the organizational structure and procedures required to prepare for and respond to discharges of oil and releases of hazardous substances, pollutants, and contaminants.
According to Section 120 of CERCLA, DOE has negotiated a Federal Facility Agreement (FFA) with EPA and SCDHEC to coordinate remedial activities at SRS into one comprehensive strategy that fulfills both RCRA 3004(u) and CERCLA investigation and remedial action requirements. Figure $6-26$ shows the location of RCRA Facility Investigation/Remedial Investigation units listed in the FFA, which was executed January 15, 1993, with an effective date of August 16, 1993.

\section{Purpose/Missions}

The SRS Site Evaluation List, Appendix G, of the FFA, identifies areas that will require an initial evaluation to determine if remedial action is necessary. Approximately 300 such areas have been identified as potential waste units at SRS. Appendix C, the RCRA/CERCLA Units List, identifies waste units that will be subject to the integrated remedial investigation program specified in the FFA. Appendix $\mathrm{H}$ of the FFA lists the RCRA-regulated units subject to corrective action under the South Carolina-designated program.

SRS is in the process of coding waste sites according to the FFA schedule. The F-Area Burning/Rubble Pits, the D-Area Burning/Rubble Pits, the Burma Road Rubble Pit, the Old F-Aréa Seepage Basin, the Silverton Road Waste Site, the M-Area West, and the L-Area Oil/Chemical Basin and Acid/Caustic Basin have an FFA fiscal year 1995 commitment for a "Corrective Measure Study/Feasibility Study Report." 


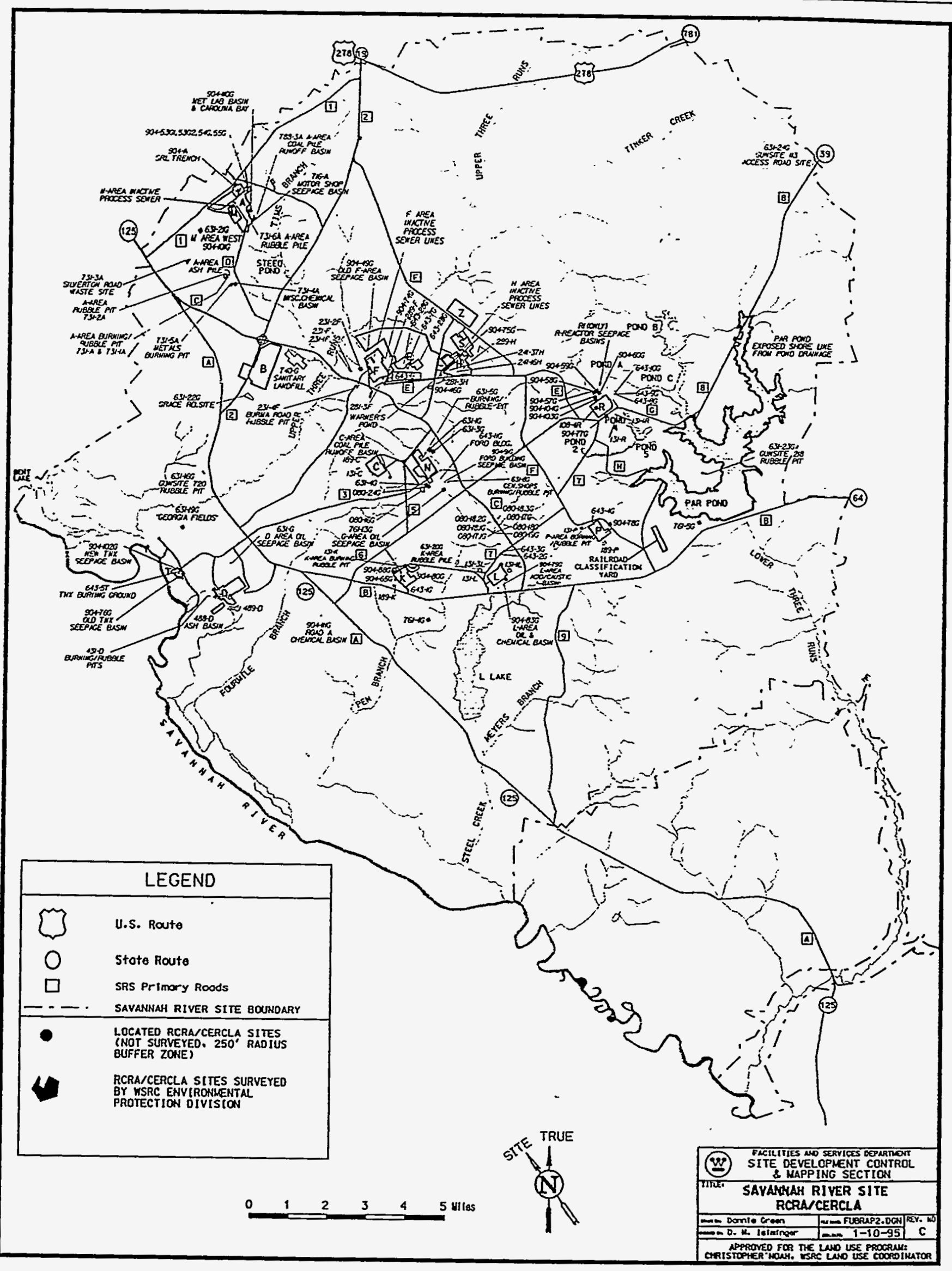

Figure 6-26 


\section{Surface Water Outfalls}

\section{Overview/Program Description}

The federal Clean Water Act of 1972 created the NPDES program, which is regulated by SCDHEC under EPA authority. The program is designed to protect surface waters by limiting all nonradiological releases of effluents into streams, reservoirs, and other wetlands. Discharge limits are set for each facility to ensure that SRS operations do not impact aquatic life adversely or decrease water quality.

\section{Purpose/Missions}

SRS has three NPDES permits-two for industrial wastewater discharge and one for general stormwater discharge. Of the 81 industrial wastewater outfalls in 1993, 67 were operational, 10 did not discharge, and four were not in service. Forty-eight stormwater-only point sources are covered under permit for stormwater discharges associated with industrial activity. Of the 48 point sources, 11 representative outfalls have been selected for monitoring (figure 6-27).

As required by the general permit, a pollution prevention plan was developed and implemented for the identified stormwater outfalls. The plan identifies facility areas where best management practices and/or best available technology should be implemented to prevent or mitigate the release of pollutants with stormwater runoff. 


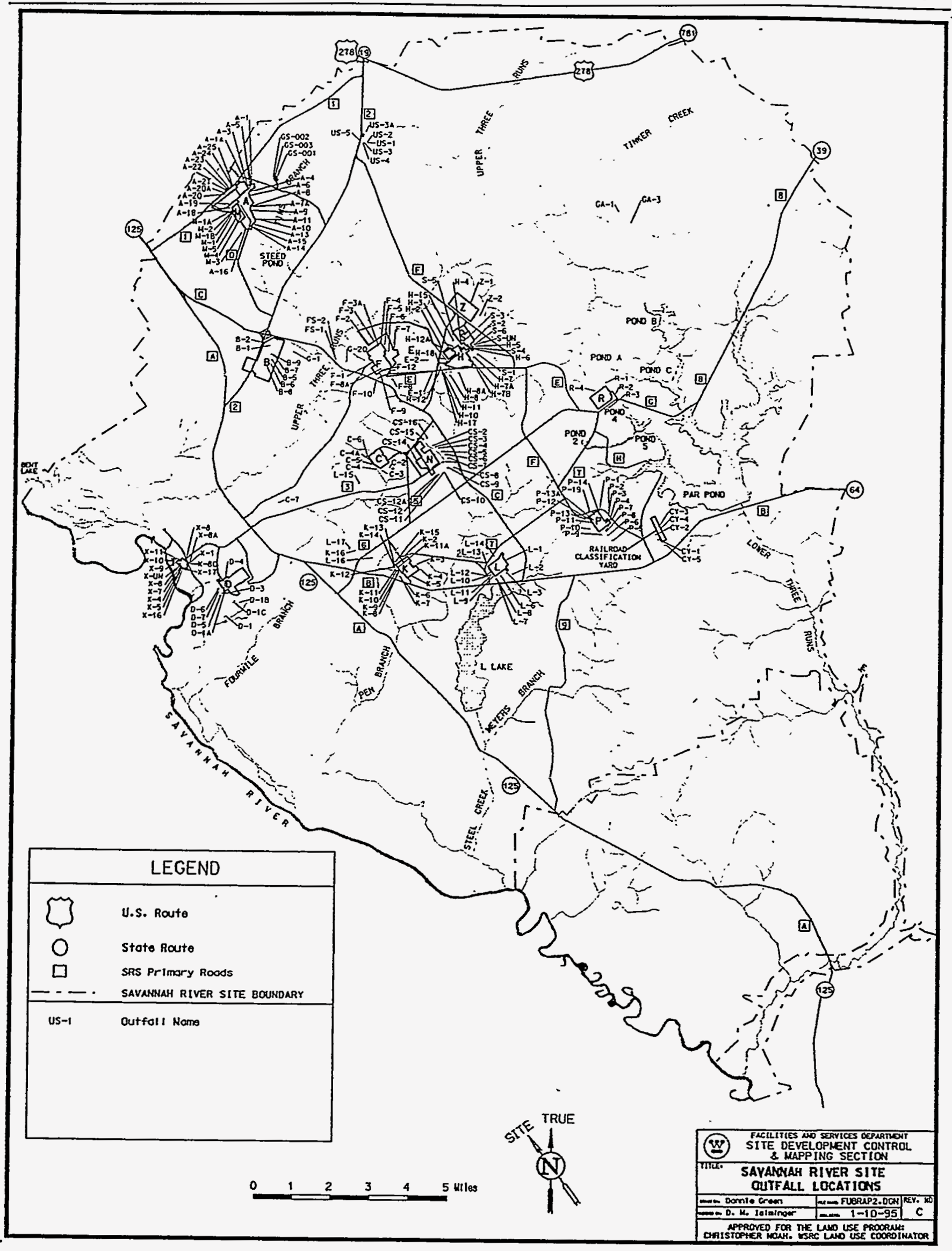

Figure 6-27 


\section{Air/Meteorological Monitoring}

\section{Overview/Program Description}

The meteorological monitoring program at SRS has been developed by the Environmental Technology Section of SRTC. The program provides current, accurate meteorological data for emergency response applications. The data are archived in large databases for application in site environmental and safety regulatory documents, such as Safety Analysis Reports, Environmental Impact Statements, and air quality calculations as part of the Clean Air Act.

\section{Purpose/Missions}

Meteorological data, which appear in the annual SRS Environmental Report, are used for calculating estimated doses to the public from SRS operations, for engineering applications, and for research and development projects involving atmospheric data. The meteorological monitoring program is regulated under "Environmental Surveillance," DOE/EH-0173 (DOE, 1991).
The site has a network of eight meteorological towers (figure 6-28). The towers are located in forested areas near the facilities with the highest potential for releases of contaminants to the environment. A fully equipped climatology station is located near Central Shops (N-Area). Its purpose is to provide additional meteorological data for engineering applications, and it also is used as a staging area for intensive atmospheric research and development projects. The facility includes a 200 -foot meteorological tower, in addition to the other instrumentation.

SRS also uses a TV tower at Beech Island-19 miles from the center of the site-that is instrumented at seven levels up to 1,000 feet. This facility gives SRS the opportunity to measure the vertical structure of the atmosphere well above the site's 200 -foot stacks, from which most releases normally are emitted. The use of such a tower is unique in the DOE complex. The tower provides a valuable database of continuous high-quality meteorological data as a cross section of the meteorological boundary layer. 


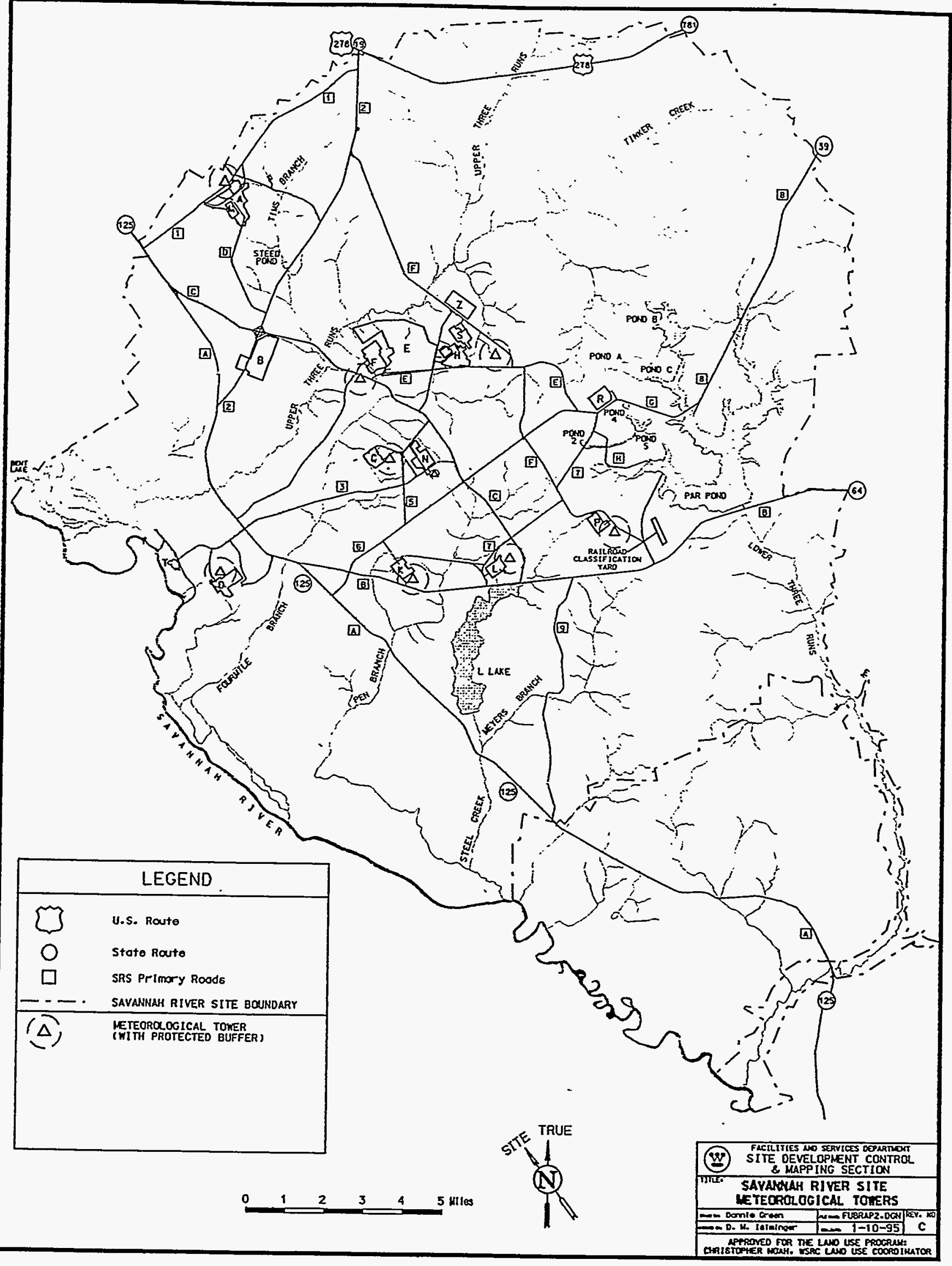

Figure 6-28 


\section{Selection of Sites for Future Missions}

\section{Overview/Program Description}

As part of the evaluation process for new missions and facilities, potential sites must be identified and characterized to determine their suitability. This screening process allows site management to determine if SRS has suitable sites for new projects, based on anticipated requirements and criteria, such as available space, infrastructure, support services, geological conditions, etc. Also, this information provides preliminary guidance to site managers and planners for input into the NEPA process.

Figure 6-29 shows the two sites that have been through the site selection process-the Solid Waste Research Complex and the Potential Tritium Production Facility. These sites will require further investigation to determine final suitability; however, preliminary planning would indicate, from a land-use perspective, that these functions could be sited appropriately at SRS. 


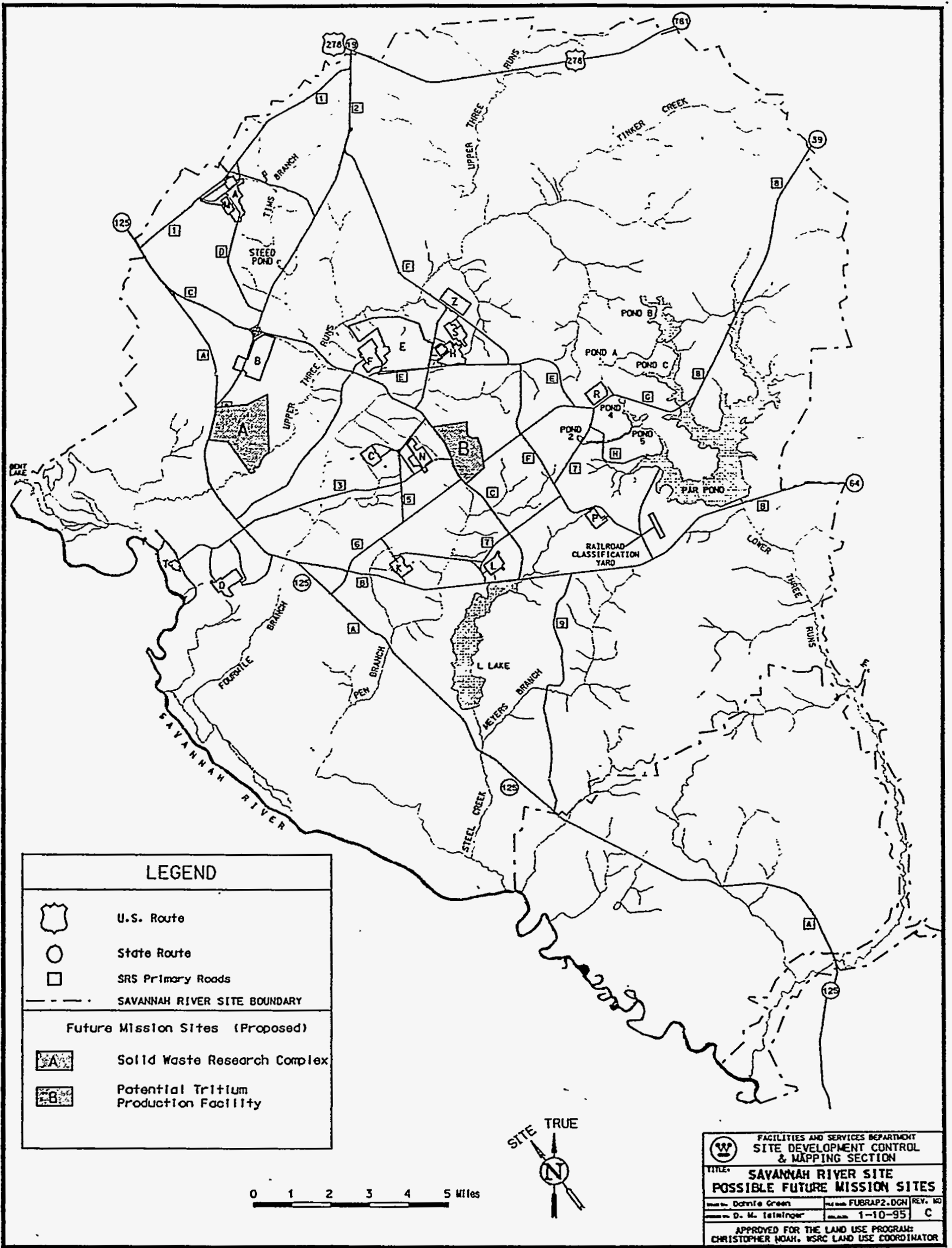

Figure 6-29 
This page left blank intentionally 


\section{Laws/Regulations/DOE Orders/Policies Affecting SRS Land Use/Transfer}

This section summarizes laws and regulations that may affect a Savannah River Site (SRS) action to dispose of surplus property. It is assumed that cleanup will have been completed on any land that would be proposed for such action; and therefore, this section does not address the laws that will govern that cleanup, primarily the Resource Conservation and Recovery Act (RCRA) and the Comprehensive Environmental Response, Compensation, and Liability Act (CERCLA).

The àpplicability of any of these laws and regulations to specific surplus-land actions will depend on the characteristics of the particular land involved and the circumstances of the proposed action. A proposal to transfer title to property does not, in itself, necessarily invoke these laws and regulations. Instead, the circumstances of the proposed transfer determine the applicability of laws and regulations.

\section{Laws/Regulations}

\section{Federal Property and Administrative Services Act of 1949 (40 USC \$483)}

Most federal property is disposed of under the authority of the Federal Property and Administrative Services Act of 1949 (FPASA) and the implementing procedures specified in the Federal Property Management Regulations (FPMR). Under this act, excess land is reported to the General Services Administration (GSA) for utilization by other executive agencies having a requirement for such property or disposal as surplus property.

Key steps leading to the transfer under FPASA are as follows:

- Reports of "excess property" are forwarded by federal agencies to the GSA at least annually.

- GSA notifies federal agencies that have functions requiring the use of real property of the availability of specific excess properties.

- Federal agencies have 30 days to identify a requirement for this excess property. If a federal agency does not respond, the property is declared "surplus."
- Prior to disposal of property by public sale, GSA provides notice to state and local governments and public institutions of the availability of such property.

- Depending on the proposed use, public agencies and institutions may be able to acquire surplus property by special statutory provisions.

- Surplus property can be obtained by public agencies and institutions, without use restrictions, through negotiated sales. Fair market value is the measurement of such transactions.

- If there is no interest from public agencies or institutions, GSA will sell the surplus property to the general public.

GSA does not have the authority to dispose of public-domain, national forest, or national park lands. Transfers of public-domain lands would be governed by different authorities and procedures, as explained under the Federal Land Policy and Management Act of 1976.

\section{Federal Land Policy and Management Act of 1976 (43 USC \$1713)}

The Federal Land Policy and Management Act of 1976 is the key statute in a collective body of laws commonly known as Public Land Laws. These laws outline policy and management of public lands, including those within the public domain. Implementing procedures and regulations are contained in the Federal Land Regulations. The controlling management agency is the United States Bureau of Land Management (BLM).

Generally, lands withdrawn from the public domain for use by a federal agency will return to the public domain when they no longer are needed or utilized by that agency. Return to the public domain would be accomplished through a revocation of the "original withdrawal." Upon completing an investigation of the proposed revocation, BLM may determine that such land is "substantially changed in character by improvements" or other actions. In such cases, the land will be referred to GSA for disposal as excess property.

If the land is considered by BLM to be suitable for return to the public domain, management and control will revert to BLM, which then can retain the land in 
public-domain status or dispose of the property. Land can be transferred through public land sale. Such land is identified for disposal if it meets the following criteria:

- Because of its location or other characteristics, the land is difficult or uneconomical to manage and is unsuitable for management by another federal agency.

- The land originally was acquired for a specific purpose but no longer is required for that or any other purpose.

- Disposal of the land will serve important public objectives, such as the expansion of communities and economic development.

\section{Atomic Energy Act of 1954 (42 USC)}

The Atomic Energy Act of 1954 gives the Department of Energy (DOE) the authority to ". . . acquire, purchase, lease, and hold real and personal property,... including patents, as agent of and on the behalf of the United States, and ... to sell, lease, grant, and dispose of such real and personal property." DOE believes that its authority to dispose of property under the Atomic Energy Act is limited to situations in which the transfer directly serves the purposes of the act, i.e., nuclear-related activities. DOE has stated that transfers to accommodate siting of hazardous waste and mixed waste facilities would not be eligible under the terms and conditions of this act.

\section{Energy Reorganization Act of 1974, as amended [42 USC §5821(B)]}

The Energy Reorganization Act of 1974 provides that fee title or other property interest may be vested in an entity other than the United States, under some circumstances, after giving Congressional notice.

\section{National Environmental Policy Act (42 USC \$4321-4370; 10 CFR 1021)}

DOE National Environmental Policy Act (NEPA) regulations list the transfer, lease, disposition, or acquisition of interests in property if the property use is to remain unchanged, as a "Categorical Exclusion," which normally does not require an environmental impact statement or environmental assessment. This would apply equally to disposal of property through the GSA or to the return of former public domain land to the Department of Interior. If the land use is to change, these regulations strongly suggest that an environmental assessment should be prepared to determine whether a full environmental impact statement is required.

\section{Endangered Species Act (16 USC $\S 1536 ; 50$ CFR 402)}

Any federal action may require a review under the Endangered Species Act, including disposal of surplus land. The Endangered Species Act is triggered only for an action that is "likely to jeopardize the continued existence of any listed species or result in the destruction or adverse modification of proposed critical habitat." Conversely, an action that is not likely to have such an effect, such as transfer of surplus land to a conservation organization (assuming the land use was to remain unchanged), would not invoke the regulations. Applicability of these regulations depends on all the circumstances of the action, as well as on the presence of a protected species.

\section{Migratory Bird Treaty Act (16 USC \$703-711; 50 CFR 10.13}

Like the other statutes discussed in this section, the Migratory Bird Treaty Act would not automatically apply to DOE land surplus action. It must be considered if the circumstances of a particular land action would pose a threat to protected birds.

The Migratory Bird Treaty Act is intended to prevent "at any time, by any means, or in any manner, to pursue, hunt, take, capture, kill, attempt to take, capture, or kill, possess, offer for sale, sell, offer to barter, barter, offer to purchase, purchase, deliver for shipment, ship, export, import, cause to be transported, canry, or cause to be carried, or receive for shipment, transportation, carriage, or export any migratory bird . ..." Courts have read the act to include virtually any activity that might harm protected birds.

\section{Bald and Golden Eagle Protection Act (16 USC §668)}

The Bald and Golden Eagle Protection Act would not automatically apply to a DOE surplus-land action. However, it must be considered if the circumstances of a particular land action would pose a threat to protected birds. It is unlawful to take, pursue, molest, or disturb bald (American) and golden eagles, their nests, or their eggs anywhere in the United States.

\section{National Historic Preservation Act (16 USC $\$ 470 ; 35$ CFR 800)}

The National Historic Preservation Act applies to any federal action, including surplus-land disposal, that could have an effect on the properties currently or potentially on the National Register of Historic Places. This act requires a historic review of any federal project activity or program that could result in changes in the character or use of historic properties. 


\section{Archaeological and Historic Preservation Act (USC $\S 460-469$ )}

The Archaeological and Historic Preservation Act applies if any "activity" is likely to result in a change of land use that might jeopardize historic or archaeological resources. A federal agency must notify the Secretary of Interior, in writing, whenever it finds that its activities may cause irreparable loss or destruction of significant scientific, prehistorical, historical, or archaeological data.

\section{American Indian Religious Freedom Act (42 USC §1996)}

The American Indian Religious Freedom Act (AIRFA) states that it is the policy of the United States to protect and preserve for Native Americans, including American Indians, Eskimos, Aleuts, and Native Hawaiians, their inherent right of freedom to believe, express, and exercise their traditional religions. These rights include access to religious sites, use and possession of sacred objects, and the freedom to worship through traditional ceremonies and rites. This act may or may not be triggered by a land surplus action. The question is whether the circumstances of proposed action are likely to result in a change in the use or degree of protection of an Indian religious site. If so, the act might become a factor in the action.

\section{Wild and Scenic Rivers Act (16 USC \$1271)}

The Wild and Scenic Rivers Act was enacted to preserve and protect the free-flowing condition of selected rivers of the United States. These rivers, with their immediate environments, possess outstanding, remarkable, and/or scenic recreational, geologic, fish and wildlife, historic, cultural, or other similar values. This act establishes a National Wild and Scenic Rivers System. Rivers in the system are designated either by Congress or by the legislatures of the states through which they flow, contingent upon approval by the Secretary of the Interior. The statute limits the ability of federal agencies to license or aid developments affecting rivers designated as potential additions to the Wild and Scenic Rivers System. This act may become applicable to some surplus-land actions.

\section{Resource Conservation and Recovery Act [USC § 6924-6945; 40 CFR 264.1(c), 117-1120, 270.40]}

The extensive provisions of RCRA goveming the generation, transportation, storage, treatment, and disposal of hazardous wastes will greatly affect the cleanup of DOE facilities. These provisions are not included in this section, however, because it is assumed that the cleanup of the land to be disposed of will have been completed in compliance with these provisions.

One provision of RCRA regulations may, however, affect disposition of land for disposal after cleanup (i.e., closure of the RCRA hazardous waste management units) is complete. The owner or operator of such units must provide post-closure care-consisting of at least monitoring, reporting, and maintenance of waste containment systems-for 30 years after closure, or as required. Notice of post-closure-care requirements is to be given to any new owner who assumes responsibility for those requirements. New owners must submit an application for a revised RCRA permit to reflect their assumption of the post-closure-care requirements and must demonstrate compliance with the RCRA financial responsibility requirements for monitoring and corrective action.

\section{Comprehensive Environmental Response, Compensatión, and Liability Act [42 USC $\$ 9620$ (h); 41 CFR 101-47.304-14]}

Along with RCRA, CERCLA largely will govern the cleanup of DOE facilities. As with RCRA, CERCLA provisions are not included in this section because it is assumed that the cleanup of any land to be disposed of will have been completed.

CERCLA requires that notice of hazardous waste activities be given to subsequent purchasers of federal land on which any hazardous substance has been stored for one year or more or is known to have been released or disposed of. Although it is not a legal restriction on the sale of the property, this notice could affect its marketability or value.

\section{Community Environmental Response Facilitation Act of 1992 (Public Law 102-426)}

The Community Environmental Response Facilitation Act of 1992 was passed as an amendment to CERCLA to require federal agencies-before they terminate their activities on real property owned by the federal 
government-to identify real property where hazardous substances were stored, released, or disposed of. The act also encourages federal agencies to work with local communities "to identify real property that offers the greatest opportunity for reuse and redevelopment."

\section{Safe Drinking Water Act [42 USC \$1424(e), 1427]}

Most of the provisions of the Safe Drinking Water Act regard standards for drinking water quality, enforcement of those standards, and protection of drinking water sources. The standards may apply to DOE as the operator of drinking water systems at its facilities, and the standards and source protection provisions may come into play during site cleanup projects. These provisions would not affect the sale of property after cleanup is complete.

One provision of the Safe Drinking Water Act might have an indirect effect on surplus property actions. The administrator of the U.S. Environmental Protection Agency (EPA) may determine that an aquifer is the sole or primary drinking water source for an area and may approve state or local demonstration programs to protect such aquifers. No commitment for federal financial assistance may be entered for any project that the administrator determines may contaminate such an aquifer or that is inconsistent with such a program. Such programs may include a comprehensive statement of land-use management.

The designation of a sole-source aquifer would not impose any direct legal constraint on the disposition of property. However, related constraints on the use of the property or on federal financial assistance to projects using the property, which might affect the aquifer, might restrict the market for the property or its value.

\section{Federal Urban Land-Use Act (12D USC §835)}

Whenever federal property situated within an urban area is to be disposed of through GSA, the administrator of GSA is to give reasonable notice to the head of the governing body of the unit of local government having zoning and land-use jurisdiction over such an area in order to afford it the opportunity to zone such land in accordance with local planning. Subsequent local decisions regarding the allowable use of the land will affect its value.

\section{DOE Orders/Federal Policies}

This section summarizes orders that may affect a DOE action to dispose of surplus property. It is assumed that cleanup will have been completed on any land that would be proposed for such action; therefore, this section does not address the orders that will govern that cleanup.

The applicability of any of these orders to specific surplus-land actions will depend upon the characteristics of the particular land involved and the circumstances of the proposed action. A proposal to transfer title to property does not, in itself, necessarily invoke these orders. Instead, the circumstances of the proposed transfer determine the applicability of each. In addition, some of these orders may affect only the value of the land when it is declared surplus.

\section{DOE Order 4300.1C, Real Property Management}

DOE Order 4300.1C, Real Property Management, establishes departmentwide policies and procedures for the acquisition, use, inventory, and disposal of real property. These activities are to be in accordance with an approved Site Development Plan.

Unless authorized by a specific act of Congress, all disposal of real property will be made under the authority of the Federal Property and Administrative Services Act of 1949 and the implementing regulations issued by the GSA. DOE has limited authority to dispose of real and related personal property. The majority of real and related personal property must be disposed of through the GSA or in conformance with regulations issued by the GSÁ.

\section{DOE Order 4320.1B, Site Development Planning}

DOE Order 4320.1B, Site Development Planning, provides guidance for land-use planning at $D O E$ sites and facilities. It requires all DOE sites to have in place a rational process for planning land use and facility development at a site. The purpose of such planning is to:

- document the need for land and facilities

- assess and update site resource requirements

- respond to the mission requirements set by senior DOE management

- project needs for a 20-year period

The site development planning process is similar to local government comprehensive planning. It attempts to gather and synthesize a large amount of data about the natural and human environment at DOE sites into a comprehensive, interrelated site description. This data - when compared to and analyzed with the site's missions, goals, and functions-is used to determine the necessary physical changes (in terms of improvements, acquisitions, demolitions, or other actions) that 
will enable DOE to continue to operate and achieve its stated goals.

\section{DOE Order 4700.1, Project Management System}

DOE Order 4700.1, Project Management System, establishes the DOE project management system and provides implementing instructions, formats, and procedures for this system. This order is intended to ensure the application of sound management principles to provide a disciplined, systematic, and coordinated approach to project management, thus achieving effective planning, organization, coordination, budgeting, management, review, and control of DOE projects.

\section{DOE Order 5000.1B, Institutional Planning by Multiprogram Laboratories}

DOE Order 5000.1B, Institutional Planning by Multiprogram Laboratories, establishes DOE policies regarding institutional planning by its multiprogram laboratories. The general characteristics of a satisfactory planning process are outlined; departmental responsibilities are defined; and the relationship of the planning process to the oversight of laboratory exploratory research and development and work for others is described. The laboratories are required to develop institutional plans annually.

\section{DOE Order 5400.1, General Environmental Protection Program}

DOE Order 5400.1, General Environmental Protection Program, establishes environmental protection program requirements, authorities, and responsibilities for DOE operations to assure compliance with applicable federal, state, and local environmental laws and regulations, executive orders, and internal departmental policies. This order requires an implementation plan that provides environmental goals and objectives and identifies strategies and schedules for meeting them. Also required is a long-range environmental protection plan to serve as a mechanism for DOE to coordinate strategies for addressing environmental needs.

\section{DOE Order 5400.2A, Environmental Compliance Issue Coordination}

DOE Order 5400.2A, Environmental Compliance Issue Coordination, establishes DOE requirements for coordination of significant environmental compliance issues to ensure timely development and consistent application of DOE environmental policies and guidance.

\section{DOE Order 5400.3, Hazardous and Radioactive Mixed Waste Program}

DOE Order 5400.3, Hazardous and Radioactive Mixed Waste Program, establishes DOE hazardous and radioactive mixed waste policies and requirements to implement the requirements of RCRA within the framework of the environmental programs.

\section{DOE Order 5400.4, Comprehensive Environmental Response, Compensation, and Liability Act Requirements}

DOE Order 5400.4, Comprehensive Environmental Response, Compensation, and Liability Act Requirements, establishes and implements DOE CERCLA policies and procedures as prescribed by the National Oil and Hazardous Substances Pollution Contingency Plan (National Contingency Plan, NCP). The order describes how DOE will enter into Inter-Agency Agreements and/or Federal Facility Agreements with federal, state, and local entities to comply with CERCLA. In addition, DOE will implement the Natural Resource Damage Assessment process, as appropriate.

\section{DOE Order 5400.5, Radiation \\ Protection of the Public and the Environment}

DOE Order 5400.5, Radiation Protection of the Public and the Environment, presents radiological protection requirements and guidelines for the cleanup of residual radioactive material, the management of resulting wastes and residues, and the release of property.

\section{DOE Order 5440.1E, National \\ Environmental Policy Act Compliance Program}

DOE Order 5440.1E, National Environmental Policy Act Compliance Program, establishes DOE responsibilities and procedures to implement the National Environmental Policy Act of 1969. NEPA establishes a national policy to ensure that consideration is given to environmental values and factors in federal planning and decision making.

\section{DOE Order 5480.4, Environmental Protection, Safety, and Health Protection Standards}

DOE Order 5480.4, Environmental Protection, Safety, and Health Protection Standards, applies to all situations in which DOE has authority to establish and enforce environmental protection, safety, and health 
(ES\&H) protection program requirements. This order specifies and provides requirements for the application of mandatory ES\&H standards, lists reference ES\&H standards, and identifies sources of mandatory and reference ES\&H standards.

\section{DOE Order 5480.5, Safety of Nuclear Facilities}

DOE Order 5480.5, Safety of Nuclear Facilities, applies to the siting, design, construction, maintenance operations, modification, and decommissioning of a given facility. Due consideration must be given to the degree of risk that the facility presents to employees, the public, and the environment.

\section{DOE Order 5480.22, Technical Safety Requirements}

DOE Order 5480.22, Technical Safety Requirements, states the requirements to have Technical Safety Requirements prepared for DOE facilities and to delineate the criteria, conduct, scope, format, approval process, and reporting requirements of these documents and revisions.

\section{DOE Order 5480.23, Nuclear Safety Analysis Reports}

DOE Order 5480.23, Nuclear Safety Analysis Reports, establishes requirements to develop safety analyses that establish and evaluate the adequacy of the safety bases of department facilities.

\section{DOE Order 5481.1B, Safety Analysis and Review Systems}

DOE Order 5481.1B, Safety Analysis and Review Systems, establishes uniform requirements for the preparation and review of safety analyses of $D O E$ operations, including the identification, elimination, and/or control of hazards; the assessment of risk; and the documented management authorization of the operations.

\section{DOE Order 5482.1B, Environment, Safety, and Health Appraisal Program}

DOE Order 5482.IB, Environment, Safety, and Health Appraisal Program, establishes the ES\&H Appraisal Program for DOE. The program encompasses the DOE requirements, activities, and functions in the conduct of all DOE operations concemed with controlling air, water, and soil pollution; limiting risks to the well-being of operating personnel and the general public to acceptably low levels; and protecting property adequately against accidental loss and damage.

\section{DOE Order 5500.3A, Planning and Preparedness for Operational Emergencies}

DOE Order 5500.3A, Planning and Preparedness for Operational Emergencies, establishes requirements for planning and preparedness for operational emergencies involving $D O E$ or requiring $D O E$ assistance. The $D O E$ Emergency Management System is comprised of several comprehensive emergency management concepts, such as planning, preparedness, and response.

DOE Order 5632.6, Physical

Protection of DOE Property and Unclassified Facilities

DOE Order 5632.6, Physical Protection of DOE Property and Unclassified Facilities, establishes 1) DOE policies and procedures for the physical protection of DOE property and unclassified facilities and 2) baseline physical protection requirements and standards for those interests.

\section{DOE Order 5820.2A, Radioactive Waste Management}

DOE Order 5820.2A, Radioactive Waste Management, establishes policies, guidelines, and minimum requirements by which DOE manages its radioactive and mixed waste and contaminated facilities.

\section{DOE Order N 4700.5, Project Control System Guidelines}

DOE Order N 4700.5, Project Control System Guidelines, establishes the DOE policy for applying control systems to the overall management of projects-including major system acquisitions, major projects, other line item projects, and general plant projects-and to the operation of funded projects and contracts within those projects.

\section{Secretary of Energy Notice (SEN) 12B-91, Nuclear Weapons Complex Reconfiguration Program}

The Defense Program's Weapons Complex Reconfiguration Office will develop "Complex 21" from the current complex-adhering to the principle of minimizing the number of weapons production sites and the size of individual sites-and will identify sites that may be transferred to the Environmental Management (EM) Program for eventual decommissioning. 


\section{SEN-15-90, National Environmental Policy Act}

For Categorical Exclusions, DOE Headquarters will make all determinations on whether to prepare environmental assessments or environmental impact statements, as appropriate.

\section{Floodplain/Wetlands Assessments Executive Orders 11988, 11990; 10 CFR 1022)}

Federal agencies are required to 1) consider the effects of proposed actions on floodplains and wetlands, 2) avoid, to the extent possible, adverse impacts associated with the occupancy and modification of floodplains and the destruction and modification of wetlands, and 3) avoid direct and indirect support of floodplain and wetlands development when there is a practicable alternative. Agencies must determine whether floodplains or wetlands are present that may be affected by an action; assess the impacts on such floodplains or wetlands; consider alternatives to the action; and allow public review of those determinations and considerations. Like other provisions summarized in this section, applicability of the floodplain/wetland assessment process to a land disposal action depends on whether there is a potential impact.

\section{Executive Order 12898 of February 11, 1994, Federal Actions to Address Environmental Justice in Minority and Low-Income Populations}

Each federal agency shall make the achievement of environmental justice part of its mission by identifying and addressing disproportionately high and adverse human health or environmental effects of its programs, policies, and activities on minority and/or low-income populations. 
This page left blank intentionally 


\section{Appendix B}

\section{Land Use-Related Environmental Acts/Regulations/Executive Orders}

\section{FEDERAL ACTS AND REGULATIONS}

\section{STATUTE: $\quad$ Atomic Energy Act (AEA)}

\section{REGULATING AUTHORITY: Department of Energy}

\section{SHORT DESCRIPTION:}

Pursuant to the AEA, DOE is responsible for developing and maintaining a capability to produce nuclear materials required for the defense of the United States. DOE is also authorized to provide certain nondefense nuclear materials, including plutonium-238, for power generators used in civilian space missions. The act also sets forth basic policies and guidance on worker protection, and emission standards, including the principle of "As Low As Reasonably Achievable" (ALARA). ALARA describes an approach to radiation exposure control or management whereby the exposures and resulting doses are maintained as far below the limits specified for the appropriate circumstances as social, economic, technical, and practical considerations permit.

\section{STATUTE: $\quad$ Clean Air Act (CAA) of 1970 \\ Clean Air Act Amendments of 1990}

\section{REGULATING AUTHORITY: Environmental Protection Agency.(EPA) and South Carolina Department of Health and En- vironmental Control (SCDHEC)}

\section{SHORT DESCRIPTION:}

The federal Clean Air Act (CAA) establishes air quality and emission limits throughout the United States.

National Emissions Standards of Hazardous Air Pollutants (NESHAP) The National Emissions Standards of Hazardous Air Pollutants (NESHAP) is a section of the CAA which sets air quality standards for air emissions of hazardous constituents such as radionuclides, benzene and asbestos.

For radioactive emission sources which have a potential to cause greater than $0.1 \mathrm{mrem} /$ year dose to an off-site individual, NESHAP regulations require specific EPA-approved instrumentation, monitoring requirements, sampling methodology, calculations, point-source inventory and modeling. SRS has negotiated with the regulatory agencies an FFCA addressing those sources which currently do not meet the technology specified in 40 CFR 60 subpart $\mathrm{H}$. 
Benzene Program

Benzene is a hazardous constituent that will be produced in the In-Tank Precipitation (ITP), and Defense Waste Processing Facility (DWPF) processes when they begin operation. The gasoline terminals and distribution points also produce benzene emissions.

\section{Asbestos Removal Program}

Early construction projects at SRS used a significant amount of asbestos in fireproof wallboard (transit), gasket materials, ceiling tile, insulation floor tiles, roofing felt, and electric wiring. Consequently, the site has maintained an active asbestos removal program for the past six years, with only trained and licensed personnel removing asbestos. The NESHAP standard does not set a numerical threshold for asbestos fiber emissions, instead, it requires persons conducting asbestos-related activities, to follow approved procedures, and to adopt specific work practices to prevent releases of asbestos to the air. Asbestos is removed during maintenance and renovations of equipment and buildings.

\section{Clean Air Act Amendments of 1990}

There are 11 Sections identified as Titles in the new amendments. Title III addresses hazardous air pollutants and will have the most impact on SRS. Title $V$ details permitting requirements. SCDHEC submitted their State Implementation Plan (SIP) to the EPA November 1993 and it is pending approval. As Maximum Achievable Control Technology (MACT) standards are promulgated SRS will have to comply with all applicable standards. Title VI is targeted toward phasing out chlorofiuorocarbons and other ozone depleters. Title VII specifies fines and penalties, as well as "award fees" for reporting violators.

STATUTE:

Comprehensive Environmental Response, Compensation, and Liability Act (CERCLA)

\section{REGULATING AUTHORITY: Environmental Protection Agency (EPA)}

\section{SHORT DESCRIPTION:}

The Comprehensive Environmental Response, Compensation, and Liability Act (CERCLA, Public Law 96-510) as amended by the Superfund Amendments and Reauthorization Act (SARA, Public Law 99-499) in 1986, provides liability, compensation, cleanup, and emergency response for hazardous substances released to the environment. In December, 1989, SRS was officially included on the National Priority List (NPL) or Superfund List. In accordance with Section 120 of CERCLA, DOE negotiated a Federal Facility Agreement (FFA) with the EPA-Region IV and SCDHEC to coordinate CERCLA and RCRA activities at SRS into one comprehensive strategy. The agreement was signed January 15, 1993. (see Resource Conservation and Recovery Act, Facility Investigation Program)

CERCLA also requires public participation in the selection of remediation alternatives. Included in this process is the establishment of an Administrative Record that documents the remediation alternatives and allows public review of these alternatives. The draft SRS Public Involvement Plan (PIP) addresses the requirements of CERCLA, RCRA and the National Environmental Policy Act (NEPA).

CERCLA requires that the National Response Center (operated by the U. S. Coast Guard) be notified in the event that a nonpermitted release of a reportable quantity of hazardous substance or radionuclide occurs. Materials are considered "released" when they are spilled, pumped, or leaked to the environment, or, enclosed in barrels or other closed containers 
which are then lost, discarded or abandoned. The CERCLA reportable quantity varies according to the material (as specified in Table 302.4 of the CERCLA Regulations).

In the case of such a release, the National Response Center alerts the appropriate federal emergency personnel to decide if government response is appropriate and to assess the response measures taken by others. If the release of a reportable quantity could result in exposure of persons outside the boundaries of the facility (SRS boundary), the Emergency Planning and Community Right-to-Know Act (EPCRA) requires that the Local Emergency Planning Committee and the State Emergency Response commission of an area likely to be affected be notified.

Another important aspect of CERCLA is delineation of guidelines for the transfer of contaminated and uncontaminated federal property. Guidelines are set forth as to conditions for transfer, monitoring, cleanup responsibility, and liability.

\section{STATUTE:}

\section{The Emergency Planning and Community-Right-to-Know Act (EPCRA) of 1986}

\section{REGULATING AUTHORITY: Environmental Protection Agency (EPA) and SCDHEC}

\section{SHORT DESCRIPTION:}

The Emergency Planning and Community-Right-to-Know Act (EPCRA) of 1986, enacted as a provision to SARA, requires industries to report the hazardous substances used at their facilities to state and local emergency planning units. This requirement includes reporting inventories (amounts on site and typical usage) of these substances. Industries must also report all planned and unplanned releases to the environment.

Under SARA, SRS must file an annual Tier II Inventory Report by March 1 to the South Carolina Emergency Response Commission and to the local emergency planning committees in Aiken, Barnwell, and Allendale counties. SRS also supplies the report to Georgia's Emergency Response Commission as a courtesy. This inventory report lists all hazardous materials stored on site in excess of specified quantities during the previous calendar year. (As required by SCDHEC, SRS uses a Tier II report as opposed to a Tier I report. The Tier II report documents chemical-specific data and gives more information than the Tier I report. For example, on the Tier I report, acids are listed only as "acids", while the Tier II report identifies specific acids and lists them separately.

SRS must also file an annual Toxic Chemical Release Inventory Report to the EPA and SCDHEC by July 1 for regulated chemicals if the combined usage of a chemical exceeded $10,000 \mathrm{lb}$ during the previous calendar year.

\section{STATUTE: $\quad$ Endangered Species Act}

\section{REGULATING AUTHORITY: U.S. Fish and Wildlife Service \\ SHORT DESCRIPTION:}

Originally passed in 1973, provides for the designation and protection of wildife, fish, and plant species which are in danger of becoming extinct and conserves the ecosystems on 
which such species depend. The Act makes it illegal for any individual to kill, collect, remove, harass, import, or export an endangered or threatened species without a permit from the Secretary of Interior. Most administrative and regulatory actions under the Act are performed by the Fish and Wildlife Service, although the National Fisheries Service is involved in actions affecting marine species.

This act requires every federal agency to ensure that its action and those of its contractors are not likely to jeopardize the continued existence of any endangered or threatened species or result in the destruction or adverse modification of a critical habitat, unless an exemption, as defined in Sections 1536 (a)(2) and (h), has been granted by the Endangered Species Committee. At SRS, this is one of the criteria examined prior to the siting/construction of any new site facility.

\section{STATUTE: $\quad$ Federal Facility Compliance Act}

\section{REGULATING AUTHORITY: South Carolina Department of Health and Environmental Control (SCDHEC)}

\section{SHORT DESCRIPTION:}

On October 6, 1992, the Federal Facility Compliance Act (FFCA) was signed into law, waiving sovereign immunity of a Federal Facility from RCRA civil and criminal liabilities. The first deliverable was the Mixed Waste Treatment Report and Treatment Capacity Report, a DOE complex wide document sent to the EPA and to each Governor's office in the state where a DOE installation was located on April 21, 1993.

Negotiations are now underway to develop a site treatment plan between DOE, EPA and SCDHEC. A draft treatment plan is scheduled to be completed August 1994 and the final plan is scheduled to be submitted no later than February 1995. .

STATUTE:

Federal Insecticide, Fungicide, and Rodenticide Act (FIFRA)

\section{REGULATING AUTHORITY: Environmental Protection Agency (EPA)}

\section{SHORT DESCRIPTION:}

The Federal Environmental Control Act of 1972 regulates the use of classified pesticides through a certification program. WSRC's pesticide procedure controls the pesticides utilized on site and certified applicators oversee the application of classified pesticides.

\section{STATUTE: $\quad$ The Federal Water Pollution Control Act as amended by the Clean Water Act of 1977 (CWA) \\ REGULATING AUTHORITY: South Carolina Department of Health and En- vironmental Control (SCDHEC)}




\section{SHORT DESCRIPTION:}

The Clean Water Act of 1972 created the National Pollutant Discharge Elimination System (NPDES) program. This program regulated by SCDHEC under the authority of the EPA, limits nonradiological effluent discharges at each SRS outfall to ensure on-site streams meet South Carolina water quality standards. This regulation includes the Corps of Engineers (COE) 404 Wetlands Permit which regulates the discharge of dredge and fill material into wetlands.

\section{STATUTE: $\quad$ Fish and Wildlife Coordination Act}

\section{REGULATING AUTHORITY: U.S. Fish and Wildlife Service}

\section{SHORT DESCRIPTION:}

The purpose of the Fish and Wildife Coordination Act, is to assure that fish and wildlife resources receive equal consideration with other values during the planning of development projects that affect water resources. The Act requires all federal agencies to consult with the U.S. Fish and Wildlife Service in the Department of the Interior whenever an agency plans to conduct, license, or modification of a stream or a body of water. DOE may be affected if any of its water development projects fall under these described activities. Two types of activities are exempt from the Act: (1) water impoundments with a surface area of less than ten acres and (2) programs for land management and use carried out by federal agencies on land under their jurisdiction.

\section{STATUTE: $\quad$ National Environmental Policy Act (NEPA)}

\section{REGULATING AUTHORITY: Council of Environmental Quality (CEQ) SHORT DESCRIPTION:}

The National Environmental Policy Act (NEPA) provides a means to evaluate the potential environmental impacts of proposed federal activities and to examine alternatives to those actions. In 1982, a formal NEPA compliance program was established at SRS.

\section{STATUTE: $\quad$ Oil Pollution Prevention Act}

\section{REGULATING AUTHORITY: EPA and SCDHEC}

\section{SHORT DESCRIPTION:}

Establishes procedures methods and equipment and other requirements for equipment to prevent the discharge of oil from nontransportation related onshore and offshore facilities into or upon the navigable waters of the US or adjoining shorelines. SRS has a Spill Prevention Control and Countermeasures Plan (SPCC Plan). 
STATUTE: $\quad$ Resource Conservation and Recovery Act (RCRA)

$\begin{array}{ll}\text { REGULATING AUTHORITY: } & \begin{array}{l}\text { Environmental Protection Agency (EPA) and } \\ \text { South Carolina Department of Health and En- } \\ \text { vironmental Control (SCDHEC) }\end{array}\end{array}$

\section{SHORT DESCRIPTION:}

The federal Resource Conservation and Recovery Act (RCRA) regulates the management of hazardous waste, nonhazardous waste, underground storage tanks containing petroleum products and hazardous substances, and medical waste. Subtitle $C$ of RCRA mandates that hazardous wastes be treated, stored and disposed of in a manner that will minimize the threat to human health and the environment. To carry out this mandate, RCRA requires that owners and operators of hazardous waste management facilities obtain operating or postclosure care permits for certain waste management activities.

\section{Land Disposal Restrictions}

The land disposal restrictions apply to waste management activities under two environmental laws-the Resource Conservation and Recovery Act (RCRA) and the Safe Drinking Water Act (SDWA). The SDWA controls underground injection of hazardous wastes in deep wells; all other land disposal activities are regulated by RCRA.

The basic purpose of the land disposal restrictions is to discourage activities that involve placing untreated wastes in or on the land when a better treatment or destruction altemative exists. Congress established the basic framework for the land disposal restrictions when it passed the Hazardous and Solid Waste Amendments of 1984 (HSWA), Eight major final rules have been published establishing land disposal restrictions for different types of wastes and different waste management activities.

The basic component of the land disposal restriction is that EPA must establish treatment standards that are protective of human health and the environment when the wastes are land disposed. Land disposal includes placement in a landfill, surface impoundment, waste pile, injection well, land treatment facility, salt dome or salt bed formation, underground mine or cave, or concrete vault or bunker.

The treatment standards either require the use of one or more specified treatment technologies, or require that wastes be treated to meet certain concentration limits on hazardous constituents. Where concentration limits are used, EPA assumes that a waste is treated with the best demonstrated available technology (BDAT), but the concentration of hazardous constituents in any treatment residues cannot be higher than those obtained using BDAT.

Once BDAT has been identified for a particular waste, EPA next establishes an effective date for the land disposal restrictions based on the availability of BDAT capacity. The capacity determination is made on a nationwide basis; no allowance is made for the fact that waste from a specific facility might have to be shipped all the way across the country to utilize the available capacity. If inadequate capacity exists to handle additional wastes subject to the land disposal restrictions, EPA can delay the effective date of the treatment standards for up to two years. 


\section{STATUTE: $\quad$ Safe Drinking Water Act (SDWA)}

\section{REGULATING AUTHORITY: South Carolina Department of Health and Envi- ronmental Control (SCDHEC)}

\section{SHORT DESCRIPTION:}

This act requires the DOE to obtain applicable permits and satisfactorily complete required sample analyses and site inspections of public/industrial water supplies and sources of drinking water. The EPA has authorized South Carolina to regulate both public/industrial water supplies and sources of drinking water. This act also imposes requirements on the installation and maintenance of drinking water wells. (see State Regulations: South Carolina Well Standards and Regulations (R.61-71), and South Carolina Drinking Water Regulations (R.61-58)).

\section{STATUTE:}

\section{Toxic Substance Control Act (TSCA)}

\section{REGULATING AUTHORITY: Environmental Protection Agency (EPA)}

\section{SHORT DESCRIPTION:}

TSCA gives the EPA comprehensive authority to identify and control chemical substances manufactured, imported, processed or used. TSCA applies to all chemicals with the exception of nuclear materials, pesticides, food and drugs, tobacco products and fire arms related materials. Reporting and recordkeeping is mandated for new chemicals and,for any chemical that may present a substantial risk of injury to health or the environment. The objectives of TSCA include the development of adequate data to determine the health and environmental effects of chemicals and to control any chemicals that present an unreasonable risk of injury. The sections of the Act most relevant to the Department of Energy (DOE) deal with requirements for:

- Regulating certain chemicals such as polychlorinated biphenyls (PCBs) that may be used in DOE facilities or processes.

- Maintaining long-term records on adverse reactions to health and environment alleged to have been caused by a substance or mixture and to permit inspection and submit copies of such records.

TSCA's primary impact to DOE is through its regulation of PCBs. Other regulations restrict the availability of materials for purchase by the DOE. Regulations important to DOE include the following from Title 40 of the Code of Federal Regulations (CFR):

- 40 CFR 717 Records and Reports of Allegations that Chemical Substances Cause Significant Adverse Reactions to Health or the Environment

- 40 CFR 761 Polychlorinated biphenyls (PCBs) Manufacturing, Processing, Distribution in Commerce and Use Prohibitions

Determinations regarding compliance with TSCA must be made on a case-specific basis if a DOE activity involves the manufacture, processing, distribution in commerce, use, and/or 
disposal of a new or existing chemical substance or mixture that may present an unreasonable risk of injury to health or the environment.

By definition, TSCA regulated chemical substances and mixtures do not include "...any source material, special nuclear material, or byproduct material (as such terms are defined in the Atomic Energy Act of 1954 and regulations issued under such Act)..." [TSCA, Section $3(2)(B)$ (iv)]. Although TSCA excludes nuclear material, the TSCA-regulated portion of a mixed nuclear and regulated waste must comply with TSCA requirements. 


\section{STATE ACTS AND REGULATIONS}

Many of the State of South Carolina laws mirror the federal laws. As with the federal laws, SRS must comply with all applicable state laws.

\section{STATUTE: $\quad$ South Carolina Pollution Control Act \\ REGULATING AUTHORITY: South Carolina Department of Health and En- vironmental Control (SCDHEC)}

\section{SHORT DESCRIPTION:}

The public policy of the State of South Carolina is to maintain reasonable standards of purity of air and water resources. SCDHEC shall have authority to abate, control and prevent pollution.

\section{STATUTE: $\quad$ South Carolina Water Use Reporting and Coordination Act REGULATING AUTHORITY: South Carolina Water Resources Commission}

\section{SHORT DESCRIPTION:}

South Carolina Water Use Reporting and Coordination Act authorizes the South Carolina Water Resources Commission (WRC) to require reporting information relative to substantial use, withdrawal, or diversion of surface, underground or other waters of the state. Required information includes identification of the locations of wells or facilities where water is used, withdrawn, or diverted; the source and location of the water; and the total amount of water used, withdrawn, or diverted.

REGULATION: South Carolina Standards for Stormwater Management and Sediment Reduction (72-300)

REGULATING AUTHORITY: South Carolina Land Resources Conservation Commission (LRCC)

\section{SHORT DESCRIPTION:}

May 26, 1993, the Land Resources Conservation Commission (LRCC) gained regulatory oversight in South Carolina. Any land disturbance activity requires an approved pollution prevention plan prior to any construction/remediation. 


\section{SHORT DESCRIPTION:}

South Carolina Nongame and Endangered Species Act protects state nongame species in need of management and species listed by the State as endangered, threatened, sensitive or species of special concern. Consultation with the South Carolina Wildlife and Marine Resources Commission is required if a listed species is present in an area to be disturbed by construction or ongoing operation of a new facility.

\section{REGULATION: SCDHEC NPDES Permit Regulation (R.61-9)}

\section{REGULATING AUTHORITY: South Carolina Department of Health and En- vironmental Control (SCDHEC)}

\section{SHORT DESCRIPTION:}

SCDHEC NPDES Permits (SC0000175 and SC0044903) limit nonradiological effuent discharges at 82 SRS outfalls to ensure on-site streams meet South Carolina water quality standards. The permits require SRS to monitor effluents as required and submit the results monthly in a Discharge Monitoring Report. The permits also direct SRS to prepare a Best Management Practices Plan to identify and control the discharge of hazardous and toxic substances listed in 40 CFR part 117 and Tables II and III of Appendix D to 40 CFR part 22.

\section{REGULATION: South Carolina Drinking Water Regulations} (R.61-58)

\section{REGULATING AUTHORITY: South Carolina Department of Health and En- vironmental Control (SCDHEC)}

\section{SHORT DESCRIPTION:}

South Carolina Drinking Water Regulations require the DOE to obtain applicable permits and satisfactorily complete required sample analyses and site inspections of public/industrial waste supplies and sources of drinking water. The EPA has authorized South Carolina to regulate both public/industrial water supplies and sources of drinking water.

\section{REGULATION: Solid Waste Regulation (R.61-61)}

\section{REGULATING AUTHORITY: South Carolina Department of Health and En- vironmental Control (SCDHEC)}

\section{SHORT DESCRIPTION:}

Solid Waste Regulation specifies procedures to be followed for closing or abandoning solid waste disposal sites. Stipulated requirements include post-closure monitoring by at least one monitoring well with readings taken every six months for submittal to the Solid Waste Division, State Board of Health. Post-closure monitoring requirements that include the use of a monitoring well implies an assessment of the location of the water table and the downgradient direction. 
REGULATION: South Carolina Air Pollution Control Regulations (R.61-62)

REGULATING AUTHORITY: South Carolina Department of Health and Environmental Control (SCDHEC)

\section{SHORT DESCRIPTION:}

South Carolina Air Pollution Control Regulations set standard requirements for construction and operating permits and for renewing permits, and require emergency action plans to deal with releases of hazardous air pollutants.

REGULATION: South Carolina Ambient Air Quality Standards (R.61-62.5)

REGULATING AUTHORITY: South Carolina Department of Health and Environmental Control (SCDHEC)

\section{SHORT DESCRIPTION:}

South Carolina Ambient Air Quality Standards set standards for visible emissions and requirements for opacity monitoring and source tests. This regulation also sets emissions limitations for certain source types and Prevention of Significant Deterioration (PSD) requirements.

REGULATION: Industrial Solid Waste Disposal Site Regulation (R.61-66)

REGULATING AUTHORITY: South Carolina Department of Health and Environmental Control (SCDHEC)

\section{SHORT DESCRIPTION:}

Industrial Solid Waste Disposal Site Regulation requires a permit for operating any industrial solid waste system and groundwater monitoring may be required as a condition of the permit.

\section{REGULATION: South Carolina Wastewater Regulations (R.61-67)}

REGULATING AUTHORITY: South Carolina Department of Health and Environmental Control (SCDHEC)

\section{SHORT DESCRIPTION:}

South Carolina Wastewater Regulations require DOE-SR to obtain Wastewater Treatment Facility Construction Permits for the construction of any wastewater treatment facilities and sewers. After construction is completed, an operating permit must be obtained. 
REGULATIONS: South Carolina Water Classifications and Standards

(R.61-68)

South Carolina Classified Waters (R.61-69)

REGULATING AUTHORITY: South Carolina Department of Health and Environmental Control (SCDHEC)

\section{SHORT DESCRIPTION:}

South Carolina Water Classification Standards require that all SRS navigable waters meet Freshwater Standards. Classified Waters defines the usability of surface and ground waters of the State and for what they are suitable. This regulation stresses the importance of the waters of the State and how they should be maintained.

\section{REGULATION: South Carolina Landfill Regulation (R.61-70) \\ REGULATING AUTHORITY: South Carolina Department of Health and En- vironmental Control (SCDHEC)}

\section{SHORT DESCRIPTION:}

South Carolina Landfill Regulation requires an owner or operator of a solid waste disposal facility to obtain a permit to operate a sanitary landfill. In addition, observation test wells that provide reliable data on groundwater contamination must be included in the site design. The requirement for monitoring wells implies an assessment of the location of the water table and downgradient direction.

\section{REGULATION: South Carolina Well Standards and Regulations (R.61-71)}

REGULATING AUTHORITY: South Carolina Department of Health and Environmental Control (SCDHEC)

\section{SHORT DESCRIPTION:}

South Carolina Well Standards and Regulations are applicable to most newly constructed wells, including water supply wells, monitoring wells, and piezometers. These regulations establish certain minimum standards for well construction, well locations, and well closures. To satisfy this requirement, a water well record form for each well must be submitted to SCDHEC within 30 days after the completion of the well.

\section{REGULATIONS: South Carolina Hazardous Waste Management Regula- tions$$
\text { (R.61-79.124, R.61-79.260 -.270) }
$$ \\ REGULATING AUTHORITY: South Carolina Department of Health and En- vironmental Control (SCDHEC)}




\section{SHORT DESCRIPTION:}

South Carolina Hazardous Waste Management Regulations describe the requirements of the hazardous waste management program administered by the State. Hazardous waste management in the hazardous waste storage buildings (except the Mixed Waste Storage Building) are operated under a Part B Permit issued in 1987. In addition, the Part B Permit was modified in 1992 to include the Consolidated Incineration Facility and construction began in January 1993. The part B renewal permit application for the permitted facilities was submitted to DHEC and is currently under review. All other hazardous waste management activities at the SRS are currently being conducted under Interim Status Standards. As such, facilities must comply with the Interim Status Standards and must not engage in hazardous waste activities or processes not specified in the RCRA Part $A$ application. Parts

R.61-79.264 and 265 of these regulations establish minimum standards on the management of hazardous waste for owners or operators of permitted hazardous waste treatment, storage, and disposal facilities. The groundwater protection standards required by this regulation will be met once the SRS obtains its complete permit. Groundwater monitoring compliance requires extensive knowledge of the hydrogeological regime.

\section{REGULATION: South Carolina Environmental Laboratory Certification Regulations (R.61-81)}

\section{REGULATING AUTHORITY: South Carolina Department of Health and En- vironmental Control (SCDHEC)}

\section{SHORT DESCRIPTION:}

Provides a mechanism to assure the validity and quality of the data being generated for compliance with state regulations.

REGULATION: South Carolina Standards of Performance for Asbestos Abatement Operations (R.61-86.1)

\section{REGULATING AUTHORITY: South Carolina Department of Health and En- vironmental Control (SCDHEC) \\ SHORT DESCRIPTION:}

South Carolina Standards of Performance for Asbestos Removal Operations set requirements for the removal and handling of asbestos when a facility is either removed or dismantled.

REGULATION: Underground Injection Control Regulations (R.61-87)

REGULATING AUTHORITY: South Carolina Department of Health and Environmental Control (SCDHEC)

\section{SHORT DESCRIPTION:}

Underground Injection Control Regulations specify requirements for controlling the injection of materials into the ground. 
REGULATION: Underground Storage Tank Control Regulations (R.61-92)

REGULATING AUTHORITY: South Carolina Department of Health and Environmental Control (SCDHEC)

\section{SHORT DESCRIPTION:}

Underground Storage Tank Control Regulations require that all tanks installed after January 1, 1986 prevent releases due to corrosion and have a release detection system. The regulation also includes requirements for notification, permitting, installation, general operations, corrective actions, and abandonment activities.

REGULATION: South Carolina Hazardous Waste Facility Siting Standards (R.61-104)

REGULATING AUTHORITY: South Carolina Department of Health and Environmental Control (SCDHEC)

\section{SHORT DESCRIPTION:}

Creates State regulations for hazardous waste facility location standards regulations became effective in South Carolina in 1991. Under this new regulation, existing and expanding hazardous waste management facilities must submit a compliance demonstration within 180 days of the effective date of the regulation.

REGULATION: Solid Waste Management: Municipal Solid Waste Landfills (R.61-107.258)

REGULATING AUTHORITY: South Carolina Department of Health and Environmental Control (SCDHEC)

\section{SHORT DESCRIPTION:}

Establishes minimum criteria under the South Carolina Solid Waste Policy and Management Act of 1991, as amended, and all applicable federal regulations, for all municipal solid waste landfills that are used to dispose of sewage sludge.

\section{AGREEMENT: Federal Facility Agreement (FFA)}

REGULATING AUTHORITY: Environmental Protection Agency (EPA) and South Carolina Department of Health and Environmental Control (SCDHEC) 


\section{SHORT DESCRIPTION:}

Federal Facility Agreement (FFA)

In accordance with Section 120 of CERCLA, DOE has negotiated a Federal Facility Agreement (FFA) with the EPA-Region IV and SCDHEC to coordinate CERCLA and RCRA activities at SRS into one comprehensive strategy. This Agreement outlines the framework of remediation and schedules for producing work plans and site investigations. The effective date of the FFA was August 16, 1993.

\section{AGREEMENT: Land Disposal Restrictions (LDR) Federal Facility Compliance Agreement (FFCA)}

\section{REGULATING AUTHORITY: Environmental Protection Agency (EPA) SHORT DESCRIPTION:}

\section{LDR FFCA}

On March 13, 1991, EPA and DOE-SR signed a Federal Facility Compliance Agreement to address SRS mixed (radioactive and hazardous) waste compliance with RCRA LDRs. The FFCA allows SRS to continue to generate and store mixed wastes that are prohibited from land disposal. The Agreement was amended on April 24, 1992 and April 2, 1993 to address facility changes.

SRS also has a FFCA addressing requirements of the CAA. 


\section{EXECUTIVE ORDERS (EO)}

\section{EO 12580 - Superfund Implementation}

\section{EO 12088 - Federal Compliance with Pollution Control Standards (amended by Executive Order 12580, Superfund Implementation, Jan. 23, 1987)}

Requires Federal agencies to comply with applicable administrative and procedural pollution control standards established by, but not limited to, the Clean Air Act, the Noise Control Act, and Clean Water Act, the Safe Drinking Water Act, the Toxic Substances Control Act, and the Resource Conservation and Recovery Act

\section{EO 11988 - Floodplain Management}

Requires that each Federal agency must review it proposed actions to determine if any action will occur in a floodplain. The potential effects of an action that will occur in a floodplain must be evaluated, and the agency shall consider alternatives to avoid adverse effect and incompatible development in floodplains. For actions significantly affecting the quality of the human environment, the evaluations of the potential effects of a project on a floodplain will be included in the EIS prepared under NEPA.

\section{EO 11990 - Protection of Wetlands}

Requires that government agencies avoid construction in wetlands unless there are not practicable alternatives and all practicable measures are included in the program to minimize harm to wetlands that might result from such use. Early review of the proposed actions is to be provided to the public. The NEPAVIS process, as well as the need to acquire a Section 404 permit should assure that wetlands would be protected.

Additional procedures to provide for compliance with DOE Order 4700.1 , as well as training of impacted personnel in the use of the procedures, are scheduled for completion by March 31,1992 . During the interim period of noncompliance, WSRC project management personnel have been trained on DOE Order 4700.1 requirements. In the areas where internal procedures are still being developed, the requirements of DOE Order 4700.1 are being used directly. Although it could be argued that direct application of DOE Order 4700.1 (without the benefit of internal procedures) should be considered as being in compliance with DOE Order 4700.1 , the lack of such procedures has been conservatively interpreted as a noncompliance. There are no environment, safety, or health impacts associated with the noncompliance. 


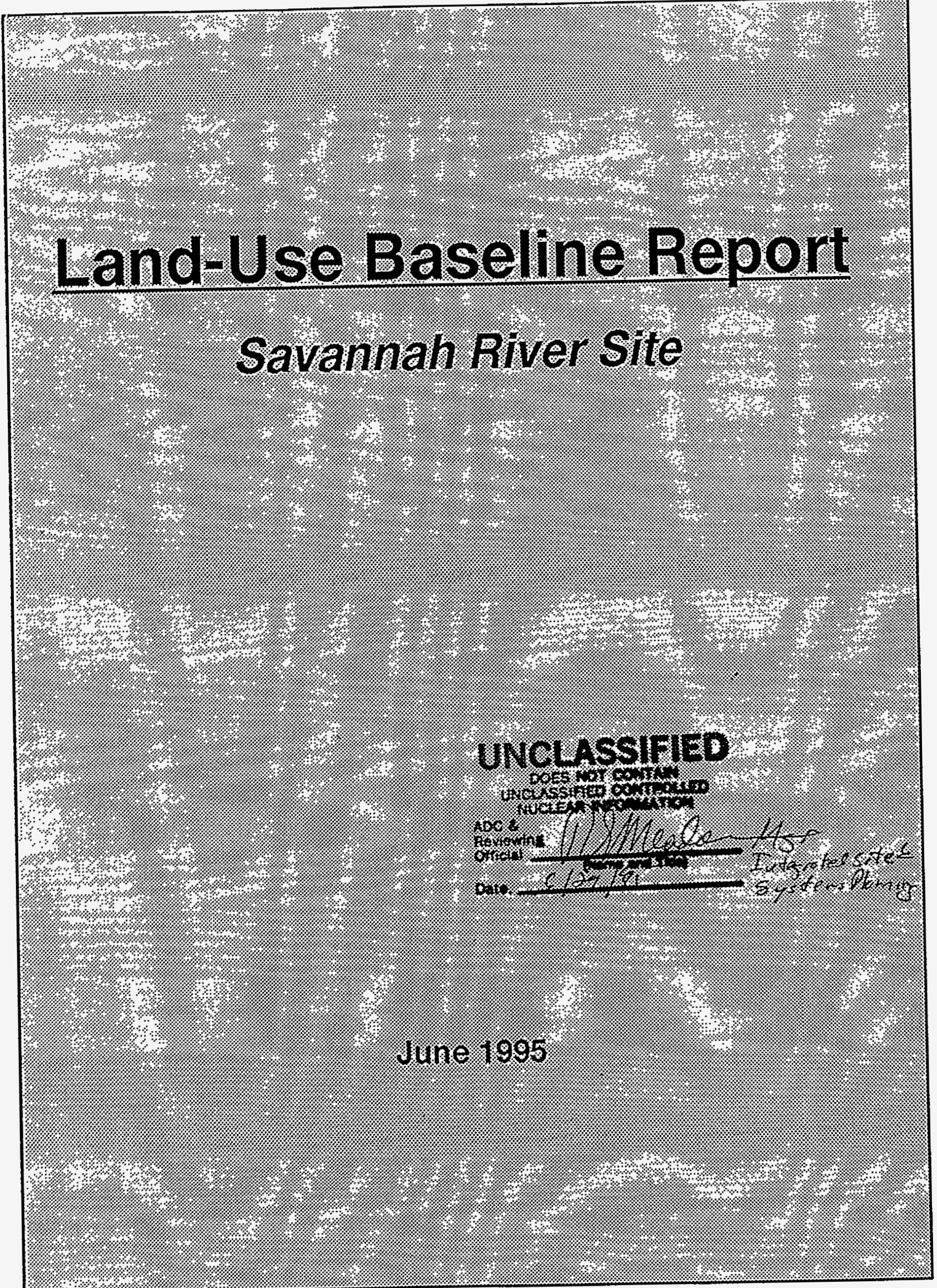

